\title{
A Mutation in Hnrnph1 That Decreases Methamphetamine- Induced Reinforcement, Reward, and Dopamine Release and Increases Synaptosomal hnRNP H and Mitochondrial Proteins
}

\author{
Qiu T. Ruan, ${ }^{1,2,3 *}$ Neema Yazdani, ${ }^{1,2,3 *}$ Benjamin C. Blum, ${ }^{4}$ Jacob A. Beierle, ${ }^{1,2,3}$ Weiwei Lin, ${ }^{4}$ Michal A. Coelho, ${ }^{5}$ \\ Elissa K. Fultz, ${ }^{5}$ Aidan F. Healy, ${ }^{5}$ John R. Shahin, ${ }^{5}$ Amarpreet K. Kandola, ${ }^{2}$ Kimberly P. Luttik, ${ }^{2}$ Karen Zheng, ${ }^{2}$ \\ Nathaniel J. Smith, ${ }^{2}$ Justin Cheung, ${ }^{2}$ Farzad Mortazavi, ${ }^{6}$ Daniel J. Apicco, ${ }^{7}$ Durairaj Ragu Varman, ${ }^{8}$ \\ Sammanda Ramamoorthy, ${ }^{8}$ Peter E.A. Ash, ${ }^{7}$ Douglas L. Rosene, ${ }^{6}$ Andrew Emili, ${ }^{4}$ Benjamin Wolozin, ${ }^{7}$ \\ Karen K. Szumlinski, ${ }^{5}$ and ${ }^{1}$ Camron D. Bryant ${ }^{1,2,3,9}$ \\ ${ }^{1}$ Biomolecular Pharmacology Training Program, Department of Pharmacology and Experimental Therapeutics, Boston University School of Medicine, \\ Boston, Massachusetts 02118, ${ }^{2}$ Laboratory of Addiction Genetics, Department of Pharmacology and Experimental Therapeutics, Boston University School \\ of Medicine, Boston, Massachusetts 02118, ${ }^{3}$ Transformative Training Program in Addiction Science, Boston University, Boston, Massachusetts 02118, \\ ${ }^{4}$ Center for Network Systems Biology, Boston University School of Medicine, Boston, Massachusetts 02118, ${ }^{5}$ Department of Psychological and Brain \\ Sciences, University of California, Santa Barbara, California 93106, ${ }^{6}$ Department of Anatomy and Neurobiology, Boston University School of Medicine, \\ Boston, Massachusetts 02118, ${ }^{7}$ Laboratory of Neurodegeneration, Department of Pharmacology and Experimental Therapeutics and Neurology, Boston \\ University School of Medicine, Boston, Massachusetts 02118, ${ }^{8}$ Department of Pharmacology \& Toxicology, Virginia Commonwealth University, Richmond, \\ Virginia 23284, and ${ }^{~}$ Department of Psychiatry, Boston University School of Medicine, Boston, Massachusetts 02118
}

Individual variation in the addiction liability of amphetamines has a heritable genetic component. We previously identified Hnrnph1 (heterogeneous nuclear ribonucleoprotein $\mathrm{H1}$ ) as a quantitative trait gene underlying decreased methamphetamine-induced locomotor activity in mice. Here, we showed that mice (both females and males) with a heterozygous mutation in the first coding exon of Hnrnph1 $\left(\mathrm{H}^{+/-}\right)$showed reduced methamphetamine reinforcement and intake and dose-dependent changes in methamphetamine reward as measured via conditioned place preference. Furthermore, $\mathrm{H} 1^{+/-}$mice showed a robust decrease in methamphetamine-induced dopamine release in the NAc with no change in baseline extracellular dopamine, striatal whole-tissue dopamine, dopamine transporter protein, dopamine uptake, or striatal methamphetamine and amphetamine metabolite levels. Immunohistochemical and immunoblot staining of midbrain dopaminergic neurons and their forebrain projections for TH did not reveal any major changes in staining intensity, cell number, or forebrain puncta counts. Surprisingly, there was a twofold increase in hnRNP H protein in the striatal synaptosome of $\mathrm{H} 1^{+/-}$mice with no change in whole-tissue levels. To gain insight into the mechanisms linking increased synaptic hnRNP $\mathrm{H}$ with decreased methamphetamine-induced dopamine release and behaviors, synaptosomal proteomic analysis identified an increased baseline abundance of several mitochondrial complex I and V proteins that rapidly decreased at 30 min after methamphetamine administration in $\mathrm{H}^{+/-}$mice. In contrast, the much lower level of basal synaptosomal mitochondrial proteins in WT mice showed a rapid increase. We conclude that $\mathrm{H}^{+/-}$decreases methamphetamine-induced dopamine release, reward, and reinforcement and induces dynamic changes in basal and methamphetamine-induced synaptic mitochondrial function.

Key words: addiction; Hnrnph1; methamphetamine; mitochondria; psychostimulants; RNA binding protein

Significance Statement

Methamphetamine dependence is a significant public health concern with no FDA-approved treatment. We discovered a role for the RNA binding protein hnRNP $\mathrm{H}$ in methamphetamine reward and reinforcement. Hnrnph1 mutation also blunted methamphetamine-induced dopamine release in the NAc, a key neurochemical event contributing to methamphetamine addiction liability. Finally, Hnrnph1 mutants showed a marked increase in basal level of synaptosomal hnRNP H and mitochondrial proteins that decreased in response to methamphetamine, whereas WT mice showed a methamphetamine-induced increase in synaptosomal mitochondrial proteins. Thus, we identified a potential role for hnRNP H in basal and dynamic mitochondrial function that informs methamphetamine-induced cellular adaptations associated with reduced addiction liability. 


\section{Introduction}

Addiction to psychostimulants, including methamphetamine (MA), is a major public health concern in the United States, with an estimated 535,000 individuals currently meeting the criteria for MA dependence (Lipari et al., 2016). Despite the prevalence of MA addiction, there is currently no FDA-approved treatment, in part because the neurobiological mechanisms underlying MA addiction are still not clear. Variation in sensitivity to the locomotor stimulant response to psychostimulants is a heritable trait and can sometimes predict differences in drug self-administration in rodents (Hooks et al., 1991; Yamamoto et al., 2013) because shared neurocircuits and neurochemical mechanisms underlie these behaviors. We recently used quantitative trait locus mapping, positional cloning, and gene editing via transcription activator-like effector nucleases to identify Hnrnph1 as a quantitative trait gene for MA sensitivity in mice (Yazdani et al., 2015). Hnrnph1 (heterogenous nuclear ribonucleoprotein $\mathrm{H} 1$ ) encodes an RNA-binding protein (RBP) that is expressed throughout the brain, and is a part of a subfamily of hnRNPs that includes hnRNP H1, hnRNP H2, and hnRNP F, which possess structurally unique quasi-RNA recognition motifs (Honoré et al., 1995). hnRNP H1 regulates all aspects of RNA metabolism, including premRNA splicing through binding at specific intronic sites, mRNA stability and translational regulation via binding to the 5'UTR and 3'UTR, and poly-adenylation control (Chou et al., 1999; Arhin et al., 2002; Katz et al., 2010; Witten and Ule, 2011; Wang et al., 2012; Song et al., 2017).

We previously demonstrated that Hnrnph1 polymorphisms and heterozygous deletion in the first coding exon of Hnrnph1 affect behavioral sensitivity to acute MA-induced locomotor stimulation; however, the effects on MA reward and reinforcement are unknown. Additionally, the neurobiological mechanism(s) underlying the mutational effects of Hnrnph1 on MA-induced behaviors remain to be established. Hnrnph1 mRNA is ubiquitously expressed throughout the adult mouse brain (Lein et al., 2007). While the protein expression of hnRNP $\mathrm{H} 1$ appears to be nuclear-restricted, studies assessing hnRNP H1 protein in the brain are limited (Kamma et al., 1995; Honoré et al., 1999; Van Dusen et al., 2010). With regard to CNS function, hnRNP $\mathrm{H}$ family proteins are described as master regulators of neuron and oligodendrocyte differentiation via alternative splicing control (Wang et al., 2007; Grammatikakis et al., 2016). Whole-exome sequencing identified coding variants in human HNRNPH1 and HNRNPH2 (located on the X chromosome) associated with severe neurodevelopmental disorders (Bain et al.,

Received July 26, 2019; revised Nov. 4, 2019; accepted Nov. 5, 2019.

Author contributions: Q.T.R., N.Y., K.K.S., and C.D.B. designed research; Q.T.R., N.Y., J.A.B., W.L., M.A.C., E.K.F., A.F.H., J.R.S., A.K.K., K.P.L., K.Z., N.J.S., J.C., D.J.A., D.R.V., S.R., and K.K.S. performed research; Q.T.R., N.Y., B.C.B., J.A.B., D.J.A., K.K.S., and C.D.B. analyzed data; Q.T.R., N.Y., D.L.R., K.K.S., and C.D.B. edited the paper; Q.T.R., N.Y., K.K.S., and C.D.B. wrote the paper; N.Y. and C.D.B. wrote the first draft of the paper; B.C.B., F.M.,P.E.A.A., D.L.R., A.E., and B.W. contributed unpublished reagents/analytic tools.

This work was supported by National Institutes of Health/National Institute on Drug Abuse Grants R00DA029635 to C.D.B., R01DA039168 to C.D.B., F31DA40324 to N.Y., and N01DA-14-7788; National Institutes of Health/National Institute of General Medical Sciences Grant T32GM008541 to N.Y., Q.T.R., and J.A.B.; and Burroughs Wellcome Fund Transformative Training Program in Addiction Science Grant 1011479 to N.Y., Q.T.R., and J.A.B. We thank Dr. Haley Melikian for providing guidance on the dopamine transporter immunoblot; and Drs. David Moody, Wenfang B. Fang, Olga Averin, and Jonathan Crites for providing the analytical service for measuring methamphetamine concentration in our biological samples.

The authors declare no competing financial interests.

${ }^{*}$ Q.T.R. and N.Y. contributed equally to this work as co-first authors.

Correspondence should be addressed to Camron D. Bryant at camron@bu.edu.

https://doi.org/10.1523/JNEUROSCI.1808-19.2019

Copyright $\odot 2020$ the authors
2016; Pilch et al., 2018), implicating a crucial role of the hnRNP H protein family in neurodevelopment.

The purpose of the present study was threefold. First, to expand beyond MA locomotor stimulant sensitivity, we examined the effect of the Hnrnph1 mutation on oral MA reinforcement and intake via operant-conditioning and MA reward via conditioned place preference (CPP). This mutation comprises a small, frameshift deletion in the first coding exon of Hnrnph1 $\left(\mathrm{H}^{+/-}\right)$ that causes reduced MA-induced locomotor activity (Yazdani et al., 2015). To gain insight into the neurobiological mechanisms underlying behavioral differences in MA sensitivity, we examined drug-induced dopamine (DA) release via in vivo microdialysis, DA content of striatal tissue, and DA clearance from striatal tissue. Second, because we previously implicated Hnrnph1 polymorphisms in dopaminergic neuron development, we assessed the effect of $\mathrm{H}^{+/-}$on TH levels in cell bodies and processes of the mesolimbic pathway via immunoblotting and immunohistochemistry (IHC). Finally, to gain insight into neural dysfunction in $\mathrm{H}^{+/-}$mice at the protein level that could underlie behavioral and neurochemical deficits, we examined the synaptosomal proteome of the striatum between the $\mathrm{H}^{+/-}$and WT mice at baseline and in response to MA.

\section{Materials and Methods}

Mice

Experimental mice were generated by mating $\mathrm{H} 1^{+/-}$males with C57BL/6J females purchased from The Jackson Laboratory (for studies at Boston University) or in Sacramento, California (for studies at the University of California at Santa Barbara). Offspring were genotyped as previously described (Yazdani et al., 2015). Unless otherwise indicated, both female and male littermates (56- to 100-d-old at the start of the experiment) were used in the studies. Mice were housed in same-sex groups of 3-5 in standard mouse cages and housed within ventilated racks under standard housing conditions. All procedures conducted in mice were approved by the Boston University, University of California at Santa Barbara, and Virginia Commonwealth University Animal Care and Use Committees. All experiments were conducted in strict accordance with the Guide for the care and use of laboratory animals. Colony rooms were maintained on a 12:12 h light-dark cycle.

Genotyping of $\mathrm{H}^{+/-}$and $\mathrm{H}^{-/-}$mice

The genotyping protocol for the $\mathrm{H} 1^{+/-}$mice was published by Yazdani et al. (2015). For genotyping of $\mathrm{H}^{-1-}$ embryo tissue, an Hnrnph1 forward primer (GATGATGCTGGGAGCAGAAG) and reverse primer (GGTCCAGAATGCACAGATTG) were designed to target upstream and downstream of the deleted region in exon 4 of Hnrnph1. Genomic DNA was used to amplify a 204 bp PCR product using DreamTaq Green PCR Mastermix (Thermo Fisher Scientific) followed by overnight restriction enzyme digest with BstNI (New England Biolabs).

Hnrmph1 and Hnrnph2 qRT-PCR for mouse embryo tissue Oligo-dT primers were used to synthesize cDNA from total RNA to examine mRNA expression and qPCR for evaluating gene expression performed using TaqMan SYBR Green (Thermo Fisher Scientific, cata$\log \# 4309155)$. The primer sequences used for evaluating expression of Hnrnph1 (targeting exons 6 and 7) were ACGGCTTAGAGGACTC CCTTT and CGTACTCCTCCCCTGGAAGT. The primer sequences used for quantifying expression of Hnrnph2 (targeting exons 1 and 2) were TAGCCGTTTGAGGGAAGAAG and CCCTGTTAGAGTTTC TTCCAGGTA. The housekeeping gene used was Hprt (targeting exons 7 and 9) with following primer sequence: GCTGGTGAAAAGGACCTCT and CACAGGACTAGAACACCTGC.

\section{Oral MA self-administration}

The procedures for MA operant conditioning were similar to those recently described (Lominac et al., 2016). Testing was conducted in operant chambers equipped with 2 nose-poke holes, 2 cue lights, a tone 
A

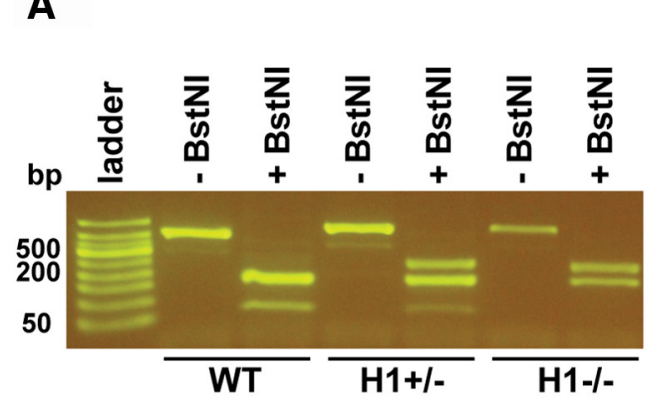

D

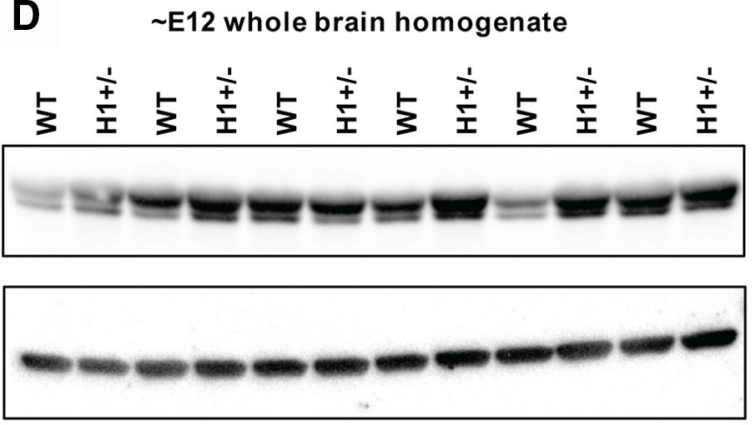

F

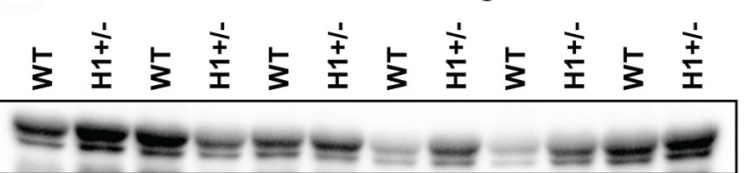

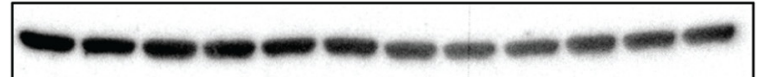

B

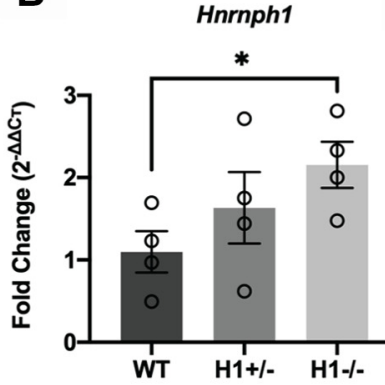

C

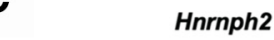

(50 kDa)

$\beta$-actin

(42 kDa)

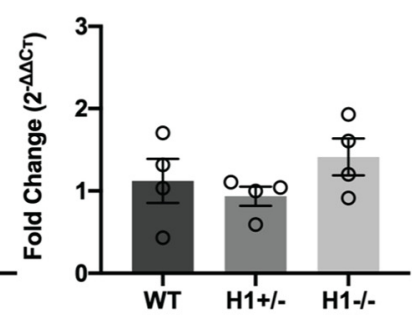

E

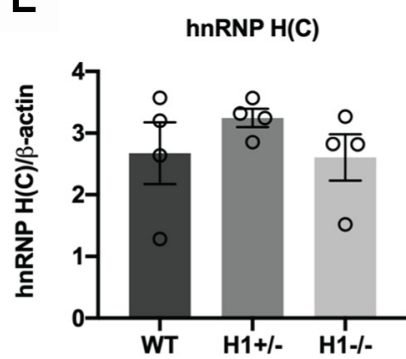

G

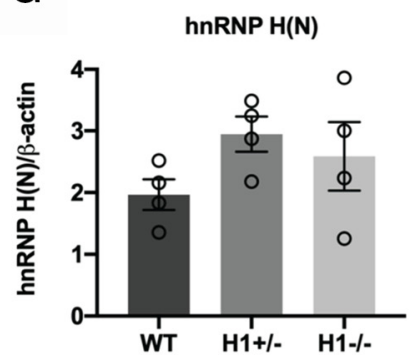

Figure 1. Hnrnph 1 whole-brain mRNA and hnRNP H whole-body protein expression in $\mathrm{WT}, \mathrm{H} 1^{+/}$, and $\mathrm{H}^{-/-}$mice. $\mathrm{H} 1^{-/-}$mice and WT littermates were generated by intercrossing $\mathrm{H} 1{ }^{+/-}$ and $\mathrm{H}^{+/-}$. Embryos were harvested at E12 for genotyping using a restriction enzyme-based assay. A, A PCR amplicon capturing the deleted region was digested with BstNI. WT mice had two copies of two BstNI restriction sites; thus, restriction digest produced three fragments $(58,157$, and $153 \mathrm{bp})$ corresponding to two bands on the gel. $\mathrm{H1}^{-1-}$ mice had two copies of a single BstNI restriction site; thus, restriction digest produced two fragments (153 and $198 \mathrm{bp}$ ). $\mathrm{H}^{+/-}$mice possessed one copy of each of the two BstNI restriction sites and one copy of a single BstNI restriction site; thus, restriction digest produced 5 fragments $(58,153,153,157$, and 198 bp) corresponding to three bands on the gel. $\boldsymbol{B}$, There was a gene dosage-dependent increase in the transcript level $H n r n p h 1$ in $\mathrm{H} 1^{+/-}$and $\mathrm{H} 1^{-1-}$ mice. The 1.5 increase in Hnnph1 transcript level in $\mathrm{H}^{+/-}$mice replicated our previously observation (Yazdani et al., 2015). The $>2$-fold increase in Hnrnph1 transcript level in $\mathrm{H}^{-I-}$ with two copies of the mutation provides further functional support for increased expression of the mutant transcript. ${ }^{*} p=0.031$ (unpaired $t$ test for WT vs $\mathrm{H}{ }^{-I-}$ ). $C$, There was no genotypic difference in Hnrnph2 transcript level. $\mathbf{D}-\mathbf{G}$, Protein expression of $h n \mathrm{RNP} \mathrm{H}$ in WT, $\mathrm{H1}^{+/-}$, and $\mathrm{H}^{-/-}$mice. There was no significant genotypic difference in hnRNP $\mathrm{H}$ protein expression using an antibody targeting the $C$ terminus of hnRNP $H(\boldsymbol{D}, \boldsymbol{E})$ or the $\mathrm{N}$ terminus of hnRNP $H(\boldsymbol{F}, \boldsymbol{G}) . n=4$ per genotype.

generator, and a liquid receptacle for fluid reinforcement (Med Associates). Mice were not water-restricted at any point during oral MA selfadministration procedures. The vehicle for MA was filtered tap water. Under a fixed-ratio 1 schedule of reinforcement, mice were trained daily to self-administer MA during $1 \mathrm{~h}$ sessions where a single active nose-poke response resulted in delivery of $20 \mu \mathrm{l}$ of liquid MA into the receptacle, with a $20 \mathrm{~s}$ illumination of the cue light, and the sounding of the tone. During the $20 \mathrm{~s}$ period, further responding resulted in no programmed consequences. Inactive hole responses were recorded but had no consequences, serving to gauge the selectivity of responding in the MAreinforced hole. Mice were initially trained to nose-poke $80 \mathrm{mg} / \mathrm{L} \mathrm{MA}$, with the concentration of MA progressively increased over weeks (120, $160,200,300$, and $400 \mathrm{mg} / \mathrm{L} \mathrm{MA} ; 5 \mathrm{~d}$ per dose). Upon the completion of each daily session, the volume of MA remaining in the receptacle was determined by pipetting and was subtracted from the volume delivered to calculate MA intake (Lominac et al., 2016).

$C P P$

Mice were trained for $1 \mathrm{~h}$ each day in Plexiglas activity boxes within sound-attenuating chambers $(40 \mathrm{~cm}$ length $\times 20 \mathrm{~cm}$ width $\times 45 \mathrm{~cm}$ tall; divided into two sides with different plastic floor textures for $\mathrm{CPP}$ ). Mice were recorded from above using infrared cameras (Swan) and tracked with ANY-maze (RRID:SCR_014289). The CPP paradigm was described by Kirkpatrick and Bryant (2015).

On training days 2-5, mice were injected with either saline (days 2 and 4) or MA (days 3 and 5; saline, 0.5 or $2 \mathrm{mg} / \mathrm{kg}$, i.p.) and confined to either the saline- or MA-paired side for $1 \mathrm{~h}$.

\section{Stereotaxic surgery}

The procedures to implant indwelling microdialysis guide cannulae bilaterally over the NAc of mice were described previously (Lominac et al., $2014,2016)$. Mice were anesthetized $<1.5 \%-2 \%$ isoflurane with $4 \%$ oxygen as a carrier gas, mounted in a Kopf stereotaxic device with tooth and ear bars adapted for mice. The mouse skull was exposed, leveled, and holes were drilled based on coordinates from bregma for the NAc (AP: $1.3 \mathrm{~mm}, \mathrm{ML}: \pm 1 \mathrm{~mm}, \mathrm{DV}:-2.3 \mathrm{~mm}$ ), according to the mouse brain atlas of Paxinos and Franklin (2001). The guide cannulae were lowered bilaterally such that the tips of the cannulae were $2 \mathrm{~mm}$ above the NAc. The skull was then prepared for polymer resin application, and the guide cannulae were secured to the skull with dental resin. After surgery, mice were injected subcutaneously with warm saline and $250 \mu \mathrm{l}$ of $2.5 \mathrm{mg} / \mathrm{ml}$ Banamine (Henry Schein Animal Health) and allowed to recover on a 
heating pad. Postoperative care was provided for $4 \mathrm{~d}$, during which mice were injected with $250 \mu \mathrm{l}$ of $2.5 \mathrm{mg} / \mathrm{ml}$ Banamine subcutaneously daily for the first $2 \mathrm{~d}$. Mice were allowed a minimum 1 week recovery before in vivo microdialysis assessments.

In vivo microdialysis and highperformance liquid chromatography (HPLC) analysis

Conventional microdialysis was conducted using a within-subjects design to examine saline and acute MA-induced DA release $(0.5$ or 2 $\mathrm{mg} / \mathrm{kg}$, i.p.), using procedures similar to those described previously (Lominac et al., 2014, 2016). Microdialysis probes were inserted unilaterally and perfused with aCSF for $3 \mathrm{~h}$ (2 $\mu \mathrm{l} / \mathrm{min}$ ), allowing for neurotransmitter equilibration. For DA no net flux analysis, DA was infused at $0,2.5,5$, and $10 \mathrm{~nm}$, and dialysate was collected in $20 \mathrm{~min}$ intervals for $1 \mathrm{~h} / \mathrm{con}$ centration. On a subsequent day, mice were probed on the contralateral side; and following the $3 \mathrm{~h}$ equilibration period and $1 \mathrm{~h}$ of baseline dialysate collection, mice were injected intraperitoneally with either 0.5 or $2.0 \mathrm{mg} / \mathrm{kg} \mathrm{MA}$, and dialysate was collected in 20 min intervals for $3 \mathrm{~h}$ after injection. HPLC analysis of DA was conducted as described previously (Lominac et al., 2014). Cannulae placement was determined on Nissl-stained coronal sections, and only mice exhibiting correct placement within the NAc were included in analyses.
A

\begin{tabular}{|l|l|}
\hline & hnRNP H1 unique peptide sequence \\
\hline 1 & MMLGAEGGEGFVVK \\
\hline 2 & MLGAEGGEGFVVK \\
\hline 3 & GLPWSCSADEVQR \\
\hline 4 & SNNVEMDWVLK \\
\hline 5 & GAYGGGYGGYDDYNGYNDGYGFGSDR \\
\hline 6 & YGDGGSTFQSTTGHCVHMR \\
\hline 7 & VTGEADVEFATHEDAVAAMSK \\
\hline 8 & YVELFLNSTAGASGGAYEHR \\
\hline
\end{tabular}

C

\begin{tabular}{|l|l|}
\hline & \multicolumn{2}{l|}{ hnRNP H2 unique peptide sequence } \\
\hline 1 & ATENDIYNFFSPLNPMR \\
\hline 2 & GAYGGGYGGYDDYGGYNDGYGFGSDR \\
\hline 3 & GLPWSCSAEEVMR \\
\hline 4 & SNSVEMDWVLK \\
\hline 5 & VTGEADVEFATHEDAVAAMAK \\
\hline 6 & YGDGGSSFQSTTGHCVHMR \\
\hline
\end{tabular}

B

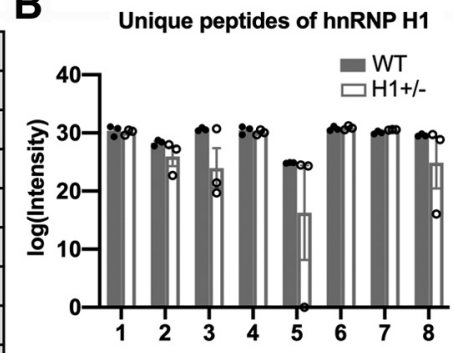

Unique peptides of hnRNP H2

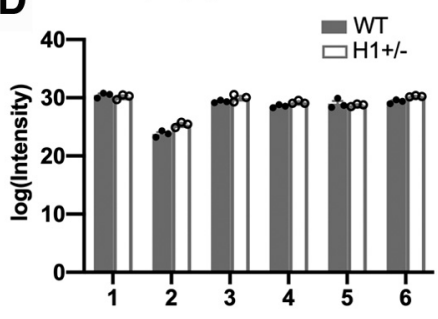

Figure 2. Quantification of hnRNP H1 and hnRNP H2 protein peptide sequences from mass spectroscopy of hnRNP H immunoprecipitates from $\mathrm{H}^{+/-}$and WT striatum. A separate cohort of mice were used for this study. Coimmunoprecipitation was used to pull down hnRNP H and associated proteins. Using the "Similarity" function in the Scaffold software, peptides exclusive to hnRNP $\mathrm{H} 1$ or hnRNP $\mathrm{H} 2$ were identified and quantified. $A$, A list is shown for the peptides that are unique to hnRNP H1. B, Quantification of peptides unique to hnRNP H1. There was a trend for a decrease in peptide GLPWSCSADEVQR in the striatum of $\mathrm{H}^{+/-}$versus WT mice ( $p=0.06$; one-tailed unpaired $t$ test). Amino acids PWSCS within this peptide are encoded by the deleted region (GCCCTGGTCCTGCTCC) in exon 4 of Hnrnph 1 in the $\mathrm{H}^{+/-}$mice. C, Table outlining the peptides that are unique to hnRNP H2. D, Quantification of hnRNP H2 unique peptides. No significant change in unique peptides of hnRNP $\mathrm{H} 2$ was observed between WT and $\mathrm{H} 1^{+/-}$ mice.

\section{Behavioral test battery}

Prepulse inhibition of acoustic startle. This test was used to assess sensorimotor gating. The apparatus and procedures were identical to those previously described by Szumlinski et al. (2005). Six trial types were conducted: startle pulse (st110, $110 \mathrm{~dB} / 40 \mathrm{~ms}$ ), low prepulse stimulus alone (st74, $74 \mathrm{~dB} / 20 \mathrm{~ms}$ ), high prepulse stimulus alone (st90, $90 \mathrm{~dB} / 20$ $\mathrm{ms}$ ), low or high prepulse stimulus given $100 \mathrm{~ms}$ before the onset of the startle pulse (pp74 and pp90, respectively), and no acoustic stimulus (st0; only background noise). All trials were presented in a randomized order; st 0 , st110, pp74, and pp90 trials were given 10 times, whereas st74 and st 90 were presented five times. Background noise in each chamber was $70 \mathrm{~dB}$, and the average intertrial interval lasted $15 \mathrm{~s}$.

Novel object test. To assess anxiety-like behavior, mice were placed into a rectangular box $(9.25 \times 17.75 \times 8$ inches high $)$ containing one small, inedible object for $2 \mathrm{~min}$. During that time, animals were allowed to explore and interact with the object. The number of contacts and time in contact (seconds) with the novel object were video-recorded and tracked with ANY-maze tracking software (RRID:SCR_014289). The apparatus and procedures used were identical to those previously described by Szumlinski et al. (2005).

Marble burying. The marble burying test was used to measure anxietylike defensive burying (Njung'e and Handley, 1991). In our paradigm, 12 square glass pieces $\left(2.5 \mathrm{~cm}^{2} \times 1.25 \mathrm{~cm}\right.$ high $)$ were placed in the animals' home cage, 6 at each end. The latency to start burying the marbles was determined by a blind observer using a stopwatch, and the total number of marbles buried following a $20 \mathrm{~min}$ trial was recorded.

Light/dark shuttle box. The light/dark shuttle box test was used to assess exploratory and anxiety-like behaviors. Mice were placed into a polycarbonate box ( $46 \mathrm{~cm}$ long $\times 24 \mathrm{~cm}$ high $\times 22 \mathrm{~cm}$ wide) wide containing distinct open (light) and closed (dark) environments for a 15 min trial. These two environments were separated by a central divider with an opening. Mice were first placed on the dark side, and the latency to enter the light side, number of light-side entries, and total time spent in the light-side of the shuttle box were recorded using ANY-maze tracking software (RRID:SCR_014289). An increase in latency to enter the light, uncovered, side was interpreted as an index of anxiety-like behavior.

Porsolt swim test. To assess depressive-like behavior (Porsolt et al., 1977), mice were placed into a pool ( $30 \mathrm{~cm}$ in diameter; $45 \mathrm{~cm}$ high) filled with room-temperature water up to $35 \mathrm{~cm}$ and allowed to swim for a total of 6 min. Time immobile (seconds), immobile episodes, and immobile latency (seconds) were video-recorded and tracked by ANY-maze tracking software (RRID:SCR_014289).

Accelerating rotarod. To assess motor coordination, mice were trained on the rotarod (IITC Life Science, ROTO-ROD series) for a total of 10 trials over $3 \mathrm{~d}$ : 3 trials the first $2 \mathrm{~d}$ and 4 trials on the final day. The rotarod started at 4 RPM and accelerated to 40 RPM in $60 \mathrm{~s}$. The time (seconds) it took a mouse to fall (physically falling or hanging off rotarod) was manually scored. Time on the rotarod was averaged across the total 10 trials for each mouse.

\section{Bitter/quinine taste sensitivity}

$\mathrm{H}^{+/-}$and WT mice were allowed continuous access in the home cage to 4 sipper tubes containing 0 (filtered tap water), $0.1,0.3$, and $0.6 \mathrm{mg} / \mathrm{ml}$ quinine (Sigma-Aldrich). The quinine concentrations selected for study were based on Eastwood and Phillips (2014). The mice and bottles were weighed before initial presentation, and the bottle was weighed every $24 \mathrm{~h}$ thereafter. The difference in bottle weight was used to determine the volume consumed from each solution over each $24 \mathrm{~h}$ period, the average intake from each solution, and the average total volume consumed.

\section{Quantification of baseline monoamine neurotransmitters from} whole striatal tissue

Drug-naive striatum were harvested from $\mathrm{H}_{1}{ }^{+/-}$and WT littermates and flash-frozen on dry ice. The dissected tissue was sent to Vanderbilt University Neurotransmitter Core for the quantification of monoamine neurotransmitters using HPLC wth electrochemical detection.

\section{DA transporter (DAT)-mediated DA uptake}

Saline or MA $(2.0 \mathrm{mg} / \mathrm{kg})$ was administered interperitoneally in a volume of $10 \mathrm{ml} / \mathrm{kg}$. After $2 \mathrm{~h}$ after administration $(2 \mathrm{~h}$ was chosen based on the microdialysis results), mice were decapitated, and DAT-specific $\left[{ }^{3} \mathrm{H}\right] \mathrm{DA}$ uptake from synaptosome preparations was conducted as described pre- 
A

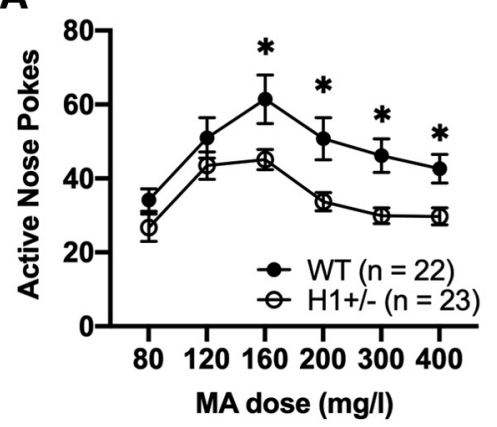

B

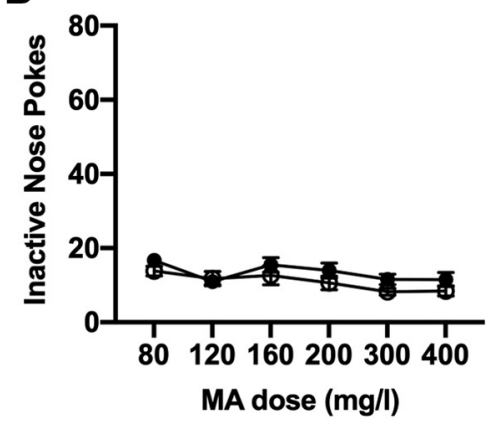

C

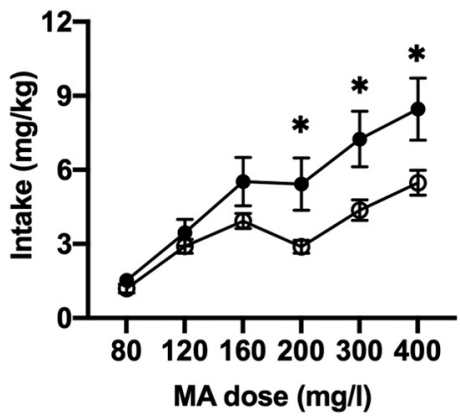

Figure 3. Oral MA self-administration in $\mathrm{H} 1^{+/-}$mice. $\mathrm{H} 1^{+/-}$mice were less sensitive than WT to the reinforcing effect of $\mathrm{MA} . \mathrm{H} 1^{+/-}$and WT mice were provided access to $80,120,160,200$, 300 , and $400 \mathrm{mg} / \mathrm{L}$ of MA for a time period of $5 \mathrm{~d}$ per dose. $A$, The average total active nose pokes emitted during five $1 \mathrm{~h}$ sessions varied as a function of MA Dose, with $\mathrm{H} 1^{+/-}$showing less active nose pokes at MA doses $160,200,300$, and $400 \mathrm{mg} / \mathrm{L}$ (unpaired $t$ test at each dose for WT vs $\mathrm{H1}^{+/-}$: for $160-400 \mathrm{mg} / \mathrm{L},{ }^{*} p<0.03$ ). B, The average total inactive nose pokes emitted during the five $1 \mathrm{~h}$ sessions varied as a function of MA Dose with no genotypic difference between $\mathrm{H}^{+/-}$and WT. $\mathrm{C}, \mathrm{H} 1^{+/-}$mice consuming less MA than WT mice at 200, 300, and 400 mg/L doses of MA (unpaired $t$ test at each dose for WT vs $\mathrm{H}^{+/-}{ }^{-}$: for $\left.200-400 \mathrm{mg} / \mathrm{L},{ }^{*} p<0.03\right) . n=23$ (10 females, 13 males) for $\mathrm{H}^{+/-}$and $n=22(9$ females, 13 males) for WT.

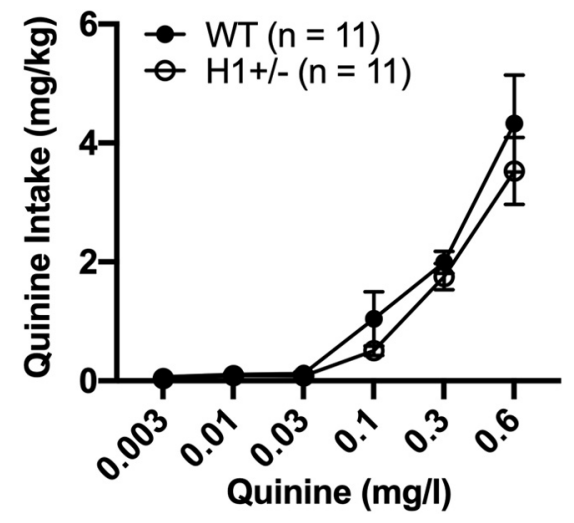

Figure 4. Bitter/quinine taste sensitivity in $\mathrm{H} 1^{+/-}$mice. Mice were allowed continuous access in the home cage to 4 sipper tubes containing $0,0.1,0.3$, and $0.6 \mathrm{mg} / \mathrm{ml}$ quinine. The difference in bottle weight was used to determine the volume consumed from each solution over each $24 \mathrm{~h}$ period, the average intake from each solution, and the average total volume consumed. There were no genotypic differences between $\mathrm{H}^{+/-}$and WT mice in average quinine intake $(0.003-0.6 \mathrm{mg} / \mathrm{ml})$.

viously (Kivell et al., 2014). Mice were rapidly decapitated, and striatal regions were dissected from the brain and collected in 10 volumes $(\mathrm{w} / \mathrm{v})$ of prechilled $0.32 \mathrm{~m}$ sucrose buffer $(0.32 \mathrm{~m}$ sucrose in $5 \mathrm{~mm}$ HEPES, $\mathrm{pH}$ 7.5). The striatal tissue was homogenized and centrifuged at $1000 \times g$ for $15 \mathrm{~min}$ at $4^{\circ} \mathrm{C}$. The supernatant was centrifuged at $12,000 \times g$ for $20 \mathrm{~min}$, and the pellet was suspended in $0.32 \mathrm{M}$ sucrose buffer. Striatal synaptosomes $(30 \mu \mathrm{g})$ were incubated in a total volume of $0.3 \mathrm{ml}$ of KrebsRinger-HEPES buffer consisting of $120 \mathrm{~mm} \mathrm{NaCl}, 4.7 \mathrm{~mm} \mathrm{KCl}, 2.2 \mathrm{~mm}$ $\mathrm{CaCl}_{2}, 10 \mathrm{~mm}$ HEPES, $1.2 \mathrm{~mm} \mathrm{MgSO}$, $1.2 \mathrm{~mm} \mathrm{KH}_{2} \mathrm{PO}_{4}, 5 \mathrm{~mm}$ Tris, 10 $\mathrm{mm}$ D-glucose, $\mathrm{pH} 7.4$ containing $0.1 \mathrm{~mm}$ ascorbic acid, and $0.1 \mathrm{~mm}$ pargyline at $37^{\circ} \mathrm{C}$ for $10 \mathrm{~min}$ with or without DAT-specific blocker GBR12909 (50 nM). Following incubation, 5 nM [ $\left.{ }^{3} \mathrm{H}\right] \mathrm{DA}$ (63.2 Ci/mmoldihydroxyphenylethylamine $[2,5,6,7,8-3 \mathrm{H}]$; PerkinElmer) and further incubated for additional $5 \mathrm{~min}$. Uptake of DA was terminated with the addition of $500 \mathrm{~nm}$ DAT blocker GBR12909. The samples were filtrated over $0.3 \%$ polyethylenimine-coated GF-B filters on a Cell Harvester (Brandel) and washed rapidly with $5 \mathrm{ml}$ cold PBS. Radioactivity bound to the filter was counted using a liquid scintillation counter. DAT-mediated $\left[{ }^{3} \mathrm{H}\right] \mathrm{DA}$ uptake was determined by subtracting total accumulation of $\left[{ }^{3} \mathrm{H}\right] \mathrm{DA}$ (absence of GBR12909) and in the presence of GBR12909. Uptake assays were performed in triplicates.

IHC

For IHC, drug-naive $\mathrm{H}^{+/-}$and WT mice were anesthetized with pentobarbital, and transcardially perfused with PBS followed by $4 \%$ PFA in $\mathrm{PBS}$ at room temperature. Next, brains were dissected and processed for
A
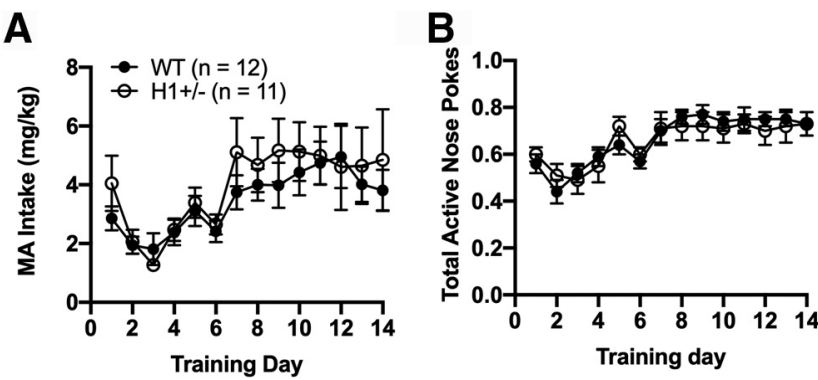

Figure 5. High-dose MA oral self-administration in $\mathrm{H} 1^{+/-}$mice. Acquisition of oral MA self-administration with initial training to respond for $200 \mathrm{mg} / \mathrm{ml}$. Mice were trained to nosepoke under a fixed-ratio 1 schedule of reinforcement ( 20 s time-out) for $20 \mu$ l delivery of a 200 $\mathrm{mg} / \mathrm{L}$ MA solution over the course of 2 weeks. While both MA intake $(\boldsymbol{A})$ and total active nose pokes $(\boldsymbol{B})$ varied across days, no genotypic differences were detected for either variable. Furthermore, there was no difference between the number of WT ( 2 of 12 ) versus $\mathrm{H} 1^{+/-}$( 3 of 11) mice that failed to meet our acquisition criteria ( $>10$ responses with $70 \%$ of responding directed at the MA-reinforced hole).

TH DAB IHC and analysis as previously described (Burke et al., 1990; Hutson et al., 2011), or double immunofluorescent IHC for hnRNP H and TH colocalization. For DAB IHC, coronal slices were blocked with $4 \%$ normal goat serum and then incubated for $48 \mathrm{~h}$ at $4^{\circ} \mathrm{C}$ with antihnRNP H (1:50,000, Bethyl, catalog \#A300-511A, RRID:AB_203269) or TH (1:500, Santa Cruz Biotechnology, catalog \#sc-14007, RRID: AB_671397), and processed for DAB staining and analyzed as previously described (Hutson et al., 2011). For costaining studies with hnRNP H and TH, tissues were blocked with superblock (Thermo Fisher Scientific, catalog \#37515), and incubated with anti-hnRNP H (Santa Cruz Biotechnology, catalog \#sc-10042, RRID:AB_2295514) and TH (1:500, Santa Cruz Biotechnology, catalog \#sc-14007, RRID:AB_671397) for $48 \mathrm{~h}$ at $4^{\circ} \mathrm{C}$. Next, tissues were incubated with donkey antirabbit AlexaFluor-488 (1:500, Invitrogen, catalog \#A-21206, RRID: AB_141708) and donkey anti-goat AlexaFluor-633 (1:500, Invitrogen, catalog \#A-21082, RRID:AB_141493), washed, and then coated with ProLong Diamond Antifade Mountant (Thermo Fisher Scientific, cata$\log \#$ P36961), mounted onto slides, and imaged on the SPE Confocal microscope (Leica Microsystems).

\section{TH puncta quantification in the striatum}

Entire coronal slices of rostral, medial, and caudal striatum were imaged at $40 \times$ magnification using a Nikon Eclipse 600 microscope. A 225,000 $\mu \mathrm{m}^{2}$ grid was overlaid onto these images using Image and every third FOV within the striatum was graded. Number of puncta within a FOV was graded in ImageJ by subtracting out background signal, creating binary images from these files, and then counting puncta meeting roundness and diameter criteria (roundness $<0.6$, diameter $1-45 \mu \mathrm{m}$ ). Aver- 
age puncta densities for ventral, dorsal, and total striatum were calculated. Grading of the puncta was performed in ImageJ. The image was duplicated into a 1,000,000 pixel area followed by brightness/contrast adjustment and background subtraction. The threshold was set to 106. A binary image was then generated for puncta measurement. Roundness was set to $0.6-1$, and size was set to 5-200 pixels.

Dissection of mouse brain regions: striatum and midbrain

Live, rapid decapitation was used to avoid the effects of anesthesia or $\mathrm{CO}_{2}$ asphyxiation on gene expression. Immediately followed live decapitation using large, sharpened shears with an incision just posterior from the ears, the mouse brain was removed quickly with forceps and transfer to a cold surface. The striatum has a somewhat darker appearance than the surrounding cortex. To dissect the dorsal and ventral striatum, fine-tip forceps were used to separate the midline of the brain, and then the cortex and hippocampus were removed to reveal the striatum. To dissect the midbrain, a razor blade was used to make a rostral cut where the cerebral aqueduct begins and another caudal cut just before the start of the cerebellum.

\section{MA-induced locomotor activity followed by tissue harvesting}

On days 1 and 2, all mice received a saline injection (10 ml/kg, i.p.) and were recorded for locomotor activity in Plexiglas chambers $(40 \mathrm{~cm}$ length $\times 20 \mathrm{~cm}$ width $\times 45 \mathrm{~cm}$ height) for $1 \mathrm{~h}$. On day 3 , mice receive either saline or MA ( $2 \mathrm{mg} / \mathrm{kg}$, i.p.; Sigma-Aldrich) and were recorded for locomotor activity for $30 \mathrm{~min}$, and the whole striatum was harvested as described above at $30 \mathrm{~min}$ after injection. Whole striata (left and right sides) were flash frozen in ethanol/dry ice bath and stored at $-80^{\circ} \mathrm{C}$ for long-term storage. Four cohorts of animals were run in this behavioral paradigm for tissue collection: (1) hnRNP H immunoprecipitation followed by mass spectroscopy; (2) synaptosome mass spectroscopy and hnRNP H immunoblot; (3) validation studies for mitochondrial protein immunoblots; and (4) measurement of MA concentration in MA-treated striatal tissues. The mice that were used for hnRNP H immunoprecipitation were all MA-treated on day 3.

\section{Quantification of MA metabolites MA-treated whole} striatal tissue

Whole striata (left and right sides) were flash frozen in ethanol/dry ice bath and stored at $-80^{\circ} \mathrm{C}$. Tissue were then shipped on dry ice to University of Utah Health Science Center for MA and amphetamine metabolite quantification as previously described (Slawson et al., 2002; DeYoung et al., 2016).

\section{Preparation of synaptosomes}

Striatal tissue collection from saline- or MA-treated mice was performed as described above. The tissues were subsequently processed to obtain synaptosomes using a Percoll (Sigma-Aldrich, catalog \#1644) gradient fractionation method, which was adapted from Dunkley et al. (2008). Whole striata (left and right hemisphere) were placed in $1 \mathrm{ml}$ sucrose homogenization buffer (2 mM HEPES, pH 7.4, 320 mm sucrose, $50 \mathrm{~mm}$ EDTA, 20 mM DTT) supplemented with protease and phosphatase inhibitor (Thermo Fisher Scientific, catalog \#78440). The brain tissues were lightly homogenized using a hand-held motorized pestle. The homogenate for each sample was then centrifuged for $2 \mathrm{~min}$ at $3000 \mathrm{rcf}$, and the supernatant (S1) was collected. The pellet (P1) was then resuspended in $500 \mu \mathrm{l}$ of sucrose homogenization buffer and respun for $3 \mathrm{~min}$ at 3000 rcf. The supernatant $\left(\mathrm{S1}^{\prime}\right)$ was collected and combined with $\mathrm{S} 1$ and then centrifuged for $15 \mathrm{~min}$ at $9200 \mathrm{rcf}$. The supernatant S2 was then removed, and the pellet (P2) was resuspended in $500 \mu$ l of sucrose homogenization buffer and loaded onto a Percoll density gradient consisting of $23 \%, 10 \%$, and $3 \%$ Percoll $(1 \mathrm{ml}$ each $)$ in polycarbonate centrifuge tubes $(13 \times 51$
Drug-free

B

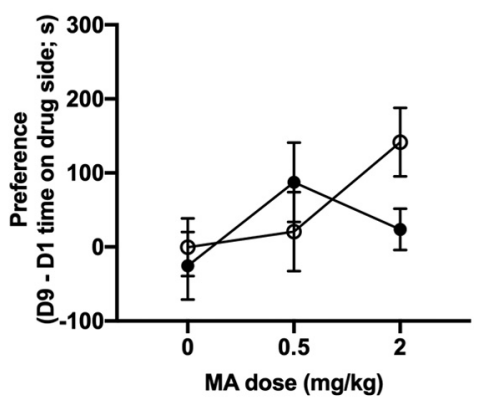

MA dose $(\mathrm{mg} / \mathrm{kg})$

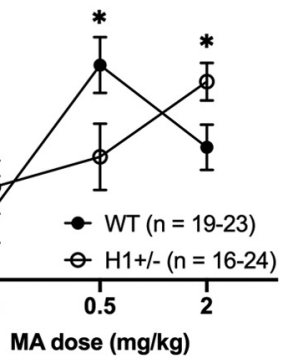

MA-state

MA dose $(\mathrm{mg} / \mathrm{kg})$

Figure 6. MA-induced CPP in $\mathrm{H} 1^{+/-}$mice. $\mathrm{H} 1^{+/-}$mice were less sensitive than WT to the rewarding effect of MA. $\boldsymbol{A}$, Genotypic differences in the time spent in the MA-paired side between day 8 and 1 (preference, seconds) were observed at 0.5 $\mathrm{mg} / \mathrm{kg}$ and $2 \mathrm{mg} / \mathrm{kg} \mathrm{MA}$ doses. $\mathrm{H}^{+/-}$mice showed lower preference at $0.5 \mathrm{mg} / \mathrm{kg}$ and higher preference at $2 \mathrm{mg} / \mathrm{kg}$ compared with WT. ${ }^{*} p<0.05$ (unpaired $t$ test for each dose for WT vs $\mathrm{H}^{+/-}$). $\boldsymbol{B}$, In examining state-dependent (PP following a challenge (has that was the same dosministered during training, a similar pattern of results (although no significant) was showing lower and higher preference at 0.5 and $2 \mathrm{mg} / \mathrm{kg}$, respectively, compared with WT. $n=24$ (16 females, 8 males), 22 ( 14 females, 8 males), and 16 ( 9 female, 7 males) at $0,0.5$, and $2 \mathrm{mg} / \mathrm{kg} \mathrm{MA} \mathrm{for} \mathrm{H}^{+/-} ; n=23$ (9 female, ales), and 19 ( 7 female, 12 males) at $0,0.5$, and $2 \mathrm{mg} / \mathrm{kg}$ MA for WT.

mm; Beckman Coulter, catalog \#349622). The gradients were then centrifuged for $15 \mathrm{~min}$ at 18,700 rcf. The distinct band between the $10 \%$ and $23 \%$ Percoll was collected as the synaptosome. The synaptosome fraction was then washed to $5 \mathrm{ml}$ with $1 \times \mathrm{HBM}$ buffer, $\mathrm{pH} 7.4(140 \mathrm{~mm} \mathrm{NaCl}, 5$ $\mathrm{mm} \mathrm{KCl}, 5 \mathrm{~mm} \mathrm{NaHCO}, 1.2 \mathrm{~mm} \mathrm{NaH}_{2} \mathrm{PO}_{4}, 1 \mathrm{~mm} \mathrm{MgCl}-6 \mathrm{H}_{2} \mathrm{O}, 10 \mathrm{~mm}$ glucose, $10 \mathrm{~mm}$ HEPES) to dilute out the Percoll by centrifuging for 12 min at $18,700 \mathrm{rcf}$. The pellet was then resuspended in $100 \mu \mathrm{l}$ of HBM buffer to yield the final synaptosme fraction, and BCA assay was used to determine protein concentration. A total of $30 \mu \mathrm{g}$ of synaptosome was loaded per sample for SDS-PAGE and Western blotting as described below.

\section{SDS-PAGE and Western blot}

Brain tissues were homogenized using hand-held homogenizer in RIPA buffer with Halt protease and phosphatase inhibitor mixture (Thermo Fisher Scientific, catalog \#78840). For each sample, $30 \mu \mathrm{g}$ of protein was heated in a $70^{\circ} \mathrm{C}$ water bath for 10 min before loading into into a $4 \%-$ $15 \%$ Criterion TGX precast Midi protein gel (Bio-Rad) for SDS-PAGE followed by wet transfer to nitrocellulose membrane. The membrane was then blocked with $5 \%$ milk for $1 \mathrm{~h}$ and probed with primary antibodies. For evaluating $\mathrm{TH}$ expression in brain tissues, overnight incubation of the membrane at $4^{\circ} \mathrm{C}$ with anti-TH $(1: 50,000$, Santa Cruz Biotechnology, catalog \#sc-14007, RRID:AB_671397) was performed followed by $1 \mathrm{~h}$ incubation with donkey anti-rabbit HRP (1:10,00, Jackson ImmunoResearch Laboratories, catalog \#711-035-152, RRID:AB_10015282). For evaluating hnRNP $\mathrm{H}$ protein expression in mouse embryo tissues and in striatal synaptosome, the following antibodies were used: hnRNP H (C-term: 1:50,000, Bethyl, catalog \#A300-511A, RRID:AB_203269; N-term: 1:50,000, Santa Cruz Biotechnology, catalog \#sc-10042, RRID: AB_2295514) followed by $1 \mathrm{~h}$ incubation with the appropriate secondary antibodies. For validation of mitochondrial protein expression following MA treatment, the following primary antibodies were used: ATP5A1 (1:2000, Abcam, catalog \#ab14748, RRID:AB_301447); ATP5F1 (1:5000, Proteintech, catalog \#15999-1-AP, RRID:AB_2258817); and NDUFS2 (1:5000; Abcam, ab192022). We used the following loading controls: anti- $\beta$-actin (1:20,000, Sigma-Aldrich, catalog \#A2228, RRID: AB_476697); anti-GAPDH (1:20,000; Millipore, catalog \#MAB374, RRID:AB_2107445); and PSD95 (1:10,000, Cell Signaling Technology, catalog \#3450, RRID:AB_2292883).

Mouse brain tissue processing for SDS-PAGE and DAT immunblotting was modified from Staal et al. (2007). Briefly, tissue was triturated using a 20-22 gauge needle in RIPA buffer (10 mm Tris, pH 7.4, $150 \mathrm{~mm}$ $\mathrm{NaCl}, 1$ mм EDTA, $0.1 \%$ SDS, $1 \%$ Triton X-100) supplemented with Halt protease and phosphatase inhibitor mixture (Thermo Fisher Scientific, catalog \#78840); $30 \mu \mathrm{g}$ of protein of each sample was allowed to rotate at room temperature before SDS-PAGE instead of heating 
SAL

A

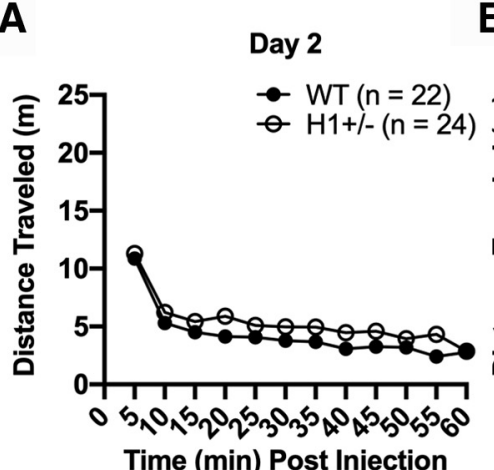

D

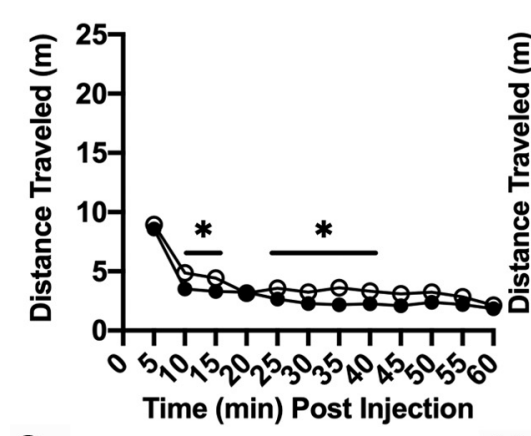

$\mathbf{G}$

Day 4

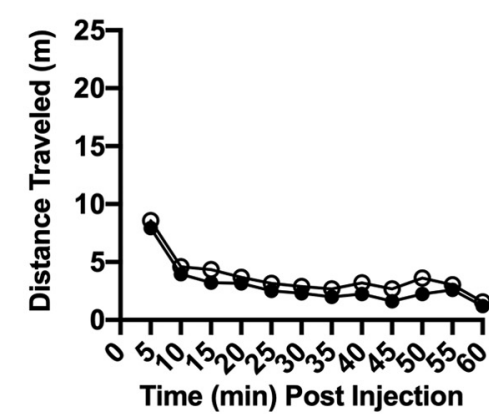

J

Day 5

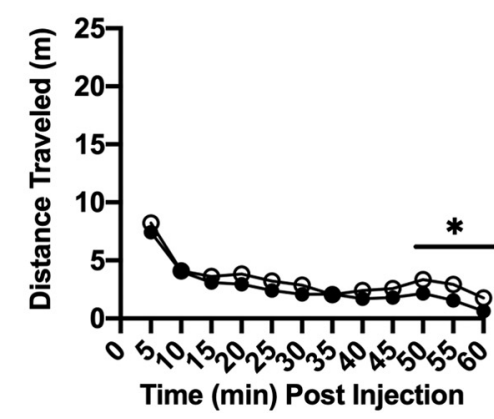

$0.5 \mathrm{mg} / \mathrm{kg}$ MA

B

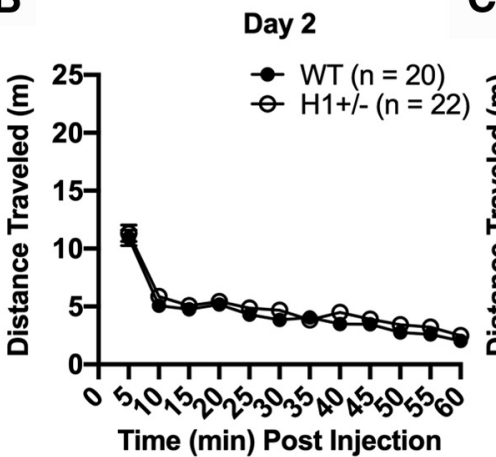

E

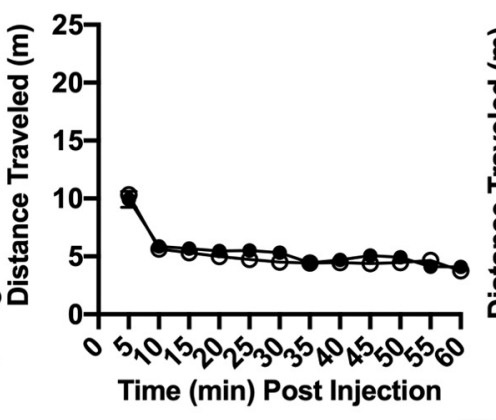

$\mathrm{H}$

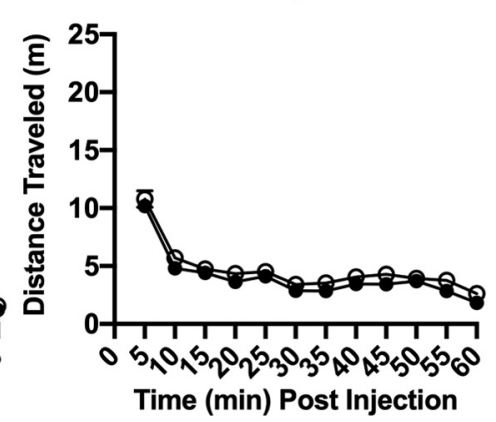

$\mathrm{K}$

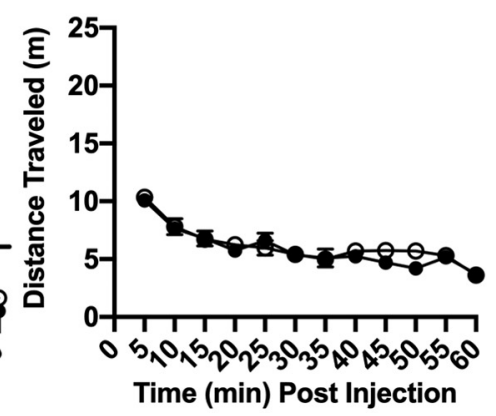

C

F

$\mathbf{L}$
$2 \mathrm{mg} / \mathrm{kg}$ MA
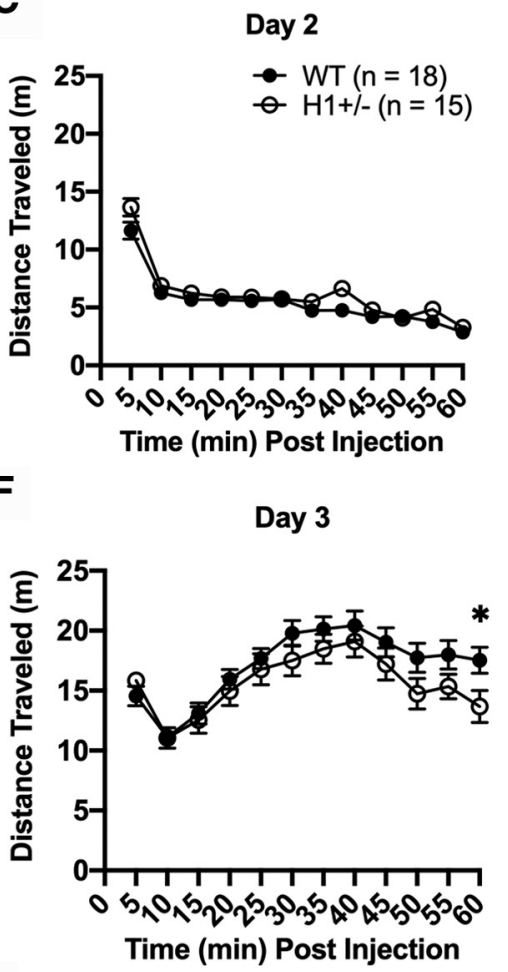

Day 4
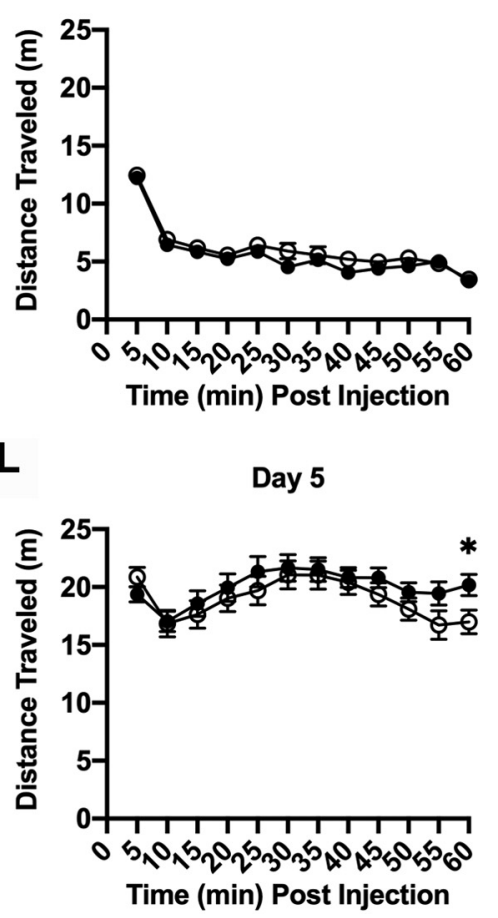

Figure 7. Locomotor activity during (PP training on days $2-5$ for $0 \mathrm{mg} / \mathrm{kg}$ (saline, SAL), $0.5 \mathrm{mg} / \mathrm{kg} \mathrm{MA}$, and $2 \mathrm{mg} / \mathrm{kg} \mathrm{MA}$ in H1 ${ }^{+/-}$mice. On days 2 and 4 , mice were injected with SAL and confined to the SAL-paired side. On days 3 and 5, mice were injected with either SAL, 0.5 or $2 \mathrm{mg} / \mathrm{kg} \mathrm{MA}$ and confined to the MA-paired side. A-C, Locomotor activity for day 2. No genotypic differences were detected for distance traveled for all three doses. $\mathbf{D}-\boldsymbol{F}$, Locomotor activity for day 3 . SAL-treated $\mathrm{H} 1^{+/-}$mice showed a greater distance traveled than SAL-treated WT from the 10 through $15 \mathrm{~min}$ time bins and from the 25 through $40 \mathrm{~min}$ time bins (unpaired $t$ tests for each $5 \mathrm{~min}$ bin for WT vs $\mathrm{H}{ }^{+/-}$: for time $=10$ and $15 \mathrm{~min},{ }^{*} p<0.007$; for time $=25$ to $40 \mathrm{~min},{ }^{*} p<$ 0.04). $\mathrm{H} 1^{+/-}$mice showed reduced distance traveled in response to $2 \mathrm{mg} / \mathrm{kg} \mathrm{MA}$ at $60 \mathrm{~min}$ after injection (unpaired $t$ test: for time $=60 \mathrm{~min},{ }^{*} p=0.03$ ). G-I, Locomotor activity for day 4 . No genotypic differences in distance traveled were detected for any of the three doses. $J-L$, Locomotor activity for day 5 . There was no difference in locomotor activity in SAL-treated WT and H $1+/-$ mice, except from the 50 to 60 min time bins with $\mathrm{H}^{+/-}$showing higher locomotor activity (unpaired $t$ tests: for the 50 through 60 min time bins, ${ }^{*} p<0.03$ ). $\mathrm{H}{ }^{+/-}$mice showed less distance traveled in response to $2 \mathrm{mg} / \mathrm{kg} \mathrm{MA} 60 \mathrm{~min}$ after injection (unpaired $t$ test: for time $=60 \mathrm{~min},{ }^{*} p=0.03$ ). 
SAL

A

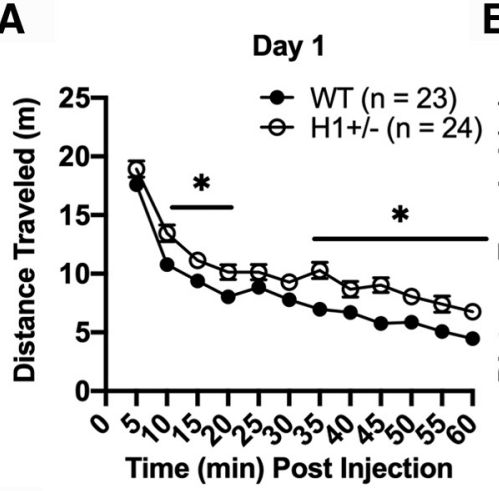

D Day $8 \quad$ E
B

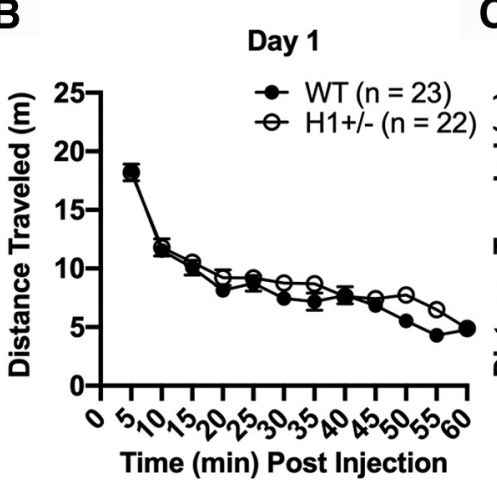

C

F $\underline{0.5 \mathrm{mg} / \mathrm{kg} M A}$

\section{2 mg/kgMA}
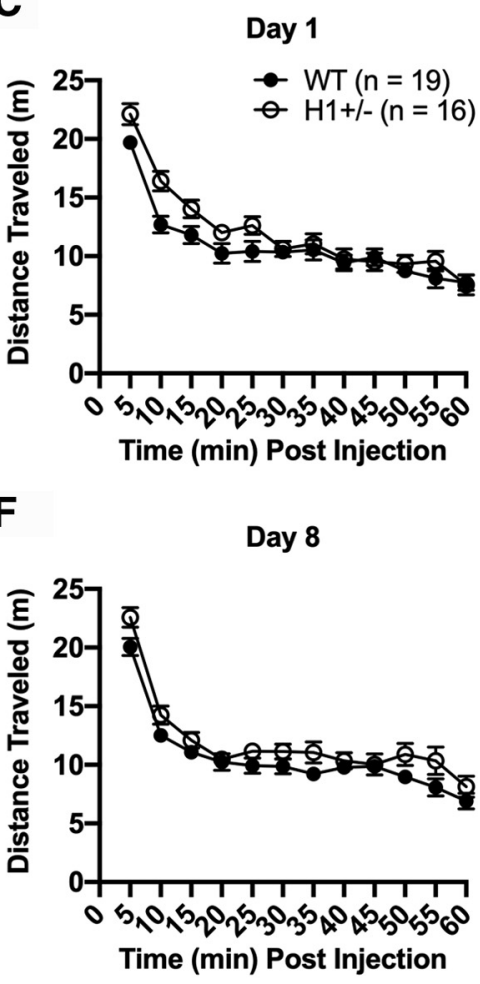

H

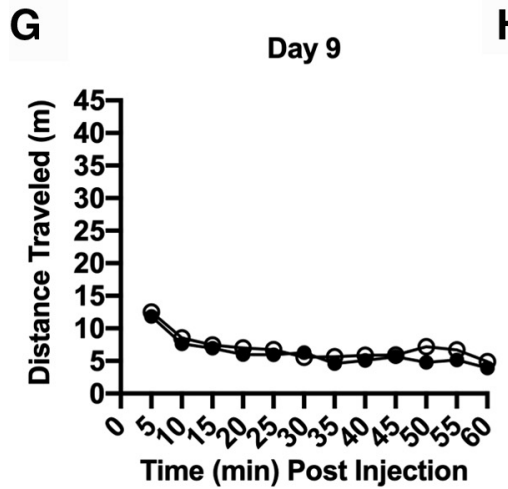

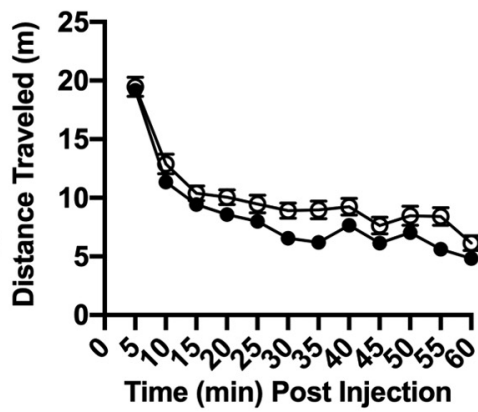
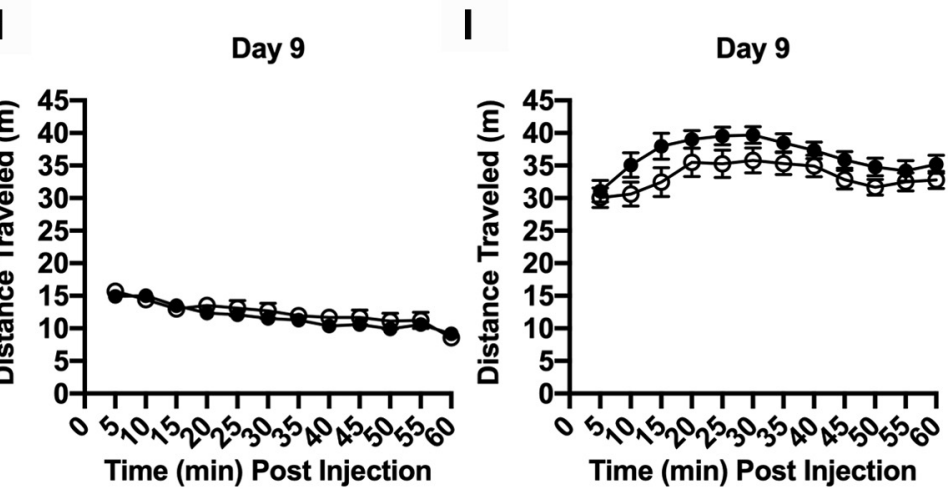

Figure 8. Locomotor activity during preference assessment in the CPP box on day 1, 8 , and 9 for $0 \mathrm{mg} / \mathrm{kg}$ (saline, SAL), $0.5 \mathrm{mg} / \mathrm{kg} \mathrm{MA}$, and $2 \mathrm{mg} / \mathrm{kg} \mathrm{MA} \mathrm{in} \mathrm{H1}{ }^{+/-}$mice. For all data shown, mice were allowed open access to both sides of the apparatus via an open entryway in the middle of the dividing wall. On day 1, mice were injected with SAL, placed into the SAL-paired side, and assessed for initial preference for the MA-paired side. On day 8, mice were injected with SAL and tested for drug-free MA-CPP. On day 9, mice were tested for state-dependent CPP with either SAL or with the same dose of MA that they received during training. A-C, Locomotor activity for day 1. For the mice that received SAL injection throughout each day of CPP testing, $\mathrm{H} 1^{+/-}$mice showed higher locomotor activity compared with WT (unpaired $t$ test for each $5 \mathrm{~min}$ bin for WT vs $\mathrm{H}^{+/-}$: for time 10 to $20 \mathrm{~min}$ and 35 to $60 \mathrm{~min}$ ). ${ }^{*} p<0.04$. No genotypic difference was detected for 0.5 and 2 $\mathrm{mg} / \mathrm{kg}$ MA dose group. $\mathbf{D}-\boldsymbol{F}$, Locomotor activity for day 8 . No genotypic difference was detected for day 8 locomotor activity for the SAL, $0.5 \mathrm{mg} / \mathrm{kg}$ and $2 \mathrm{mg} / \mathrm{kg}$ MA dose. G-I, Locomotor activity for day 9. No genotypic difference was detected for day 9 locomotor activity for the SAL, $0.5 \mathrm{mg} / \mathrm{kg}$ and $2 \mathrm{mg} / \mathrm{kg}$ MA dose. Sample sizes are indicated in the parentheses.

the sample at high temperature. For evaluating DAT expression in whole striatal tissue and striatal synaptosome, we conducted overnight incubation anti-DAT (1:2000; Millipore, catalog \#MAB369, RRID:AB_2190413) followed by $1 \mathrm{~h}$ incubation with goat anti-rat (1:500, Jackson ImmunoResearch Laboratories, catalog \#112-035003, RRID:AB_2338128).

All processed membranes were imaged via enhanced chemiluminescence photo-detection. Densitometry analysis in ImageJ was used for quantification.

\section{hnRNP H immunoprecipitation}

Following the $3 \mathrm{~d}$ locomotor paradigm assessing acute locomotor sensitivity in $\mathrm{H}^{+/-}$versus WT mice as described above, striata were dissected from the mice at $30 \mathrm{~min}$ after injection of MA or saline. Striatum was dissected from WT or $\mathrm{H}^{+/-}$mice and frozen on dry ice and stored at $-80^{\circ} \mathrm{C}$. Striatal tissues were then homogenized using a microcentrifuge pestle in ice-cold RIPA buffer ( $50 \mathrm{~mm}$ Tris-HCl, pH 6.8, $150 \mathrm{~mm} \mathrm{NaCl}, 5$ mM EDTA, $1 \%$ Triton X-100, 0.1\% SDS, 0.5\% sodium deoxycholate) supplemented with protease and phosphatase inhibitor cocktails (Thermo Fisher Scientific, catalog \#78840) and incubated overnight at $4^{\circ} \mathrm{C}$ with gentle agitation. Lysates were centrifuged at 10,000 rpm for 15 $\min$ at $4^{\circ} \mathrm{C}$, and the supernatant fraction was saved for protein quantification via BCA assay; $1 \mathrm{mg}$ of striatal lysates was precleared for $1 \mathrm{~h}$ with 80 $\mu$ l Protein G Sepharose-coated beads (Thermo Fisher Scientific, catalog $\# 101243$ ) and then centrifuged at $4^{\circ} \mathrm{C}$ for $5 \mathrm{~min}$ at $1000 \mathrm{rpm}$. The precleared lysates (supernatant) were then incubated overnight with $10 \mu \mathrm{g}$ of rabbit anti-hnRNP H (Bethyl, catalog \#A300-511A, RRID: 
A

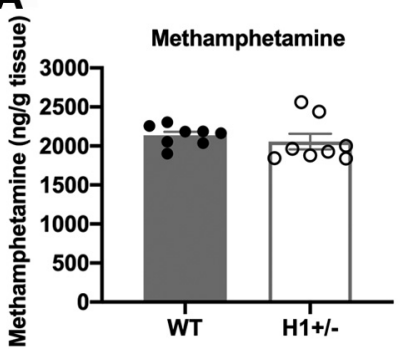

B

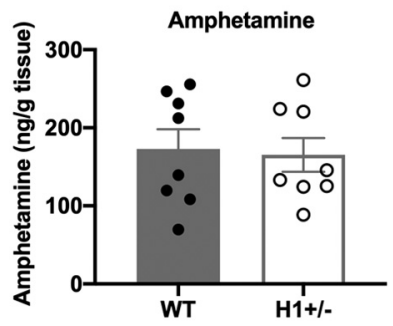

Figure 9. Concentration of MA and amphetamine in the striatum at $30 \mathrm{~min}$ after MA injection in $\mathrm{H}^{+/-}$mice. On days 1 and 2, mice were injected (i.p.) with saline and placed into apparatus for $1 \mathrm{~h}$. On day 3 , mice were injected (i.p.) with $2 \mathrm{mg} / \mathrm{kg} \mathrm{MA}$ and placed into apparatus for $30 \mathrm{~min}$ followed by subsequent removal of the striatum. $A$, No genotypic difference was detected in the striatal concentration of MA. $\boldsymbol{B}$, Also, no genotypic difference was detected in the striatal concentration of amphetamine. $n=8$ per genotype.

AB_203269) or control normal rabbit IgG antibody (Millipore, catalog \#NI01-100UG, RRID:AB_490574). The next day, $80 \mu$ l of Protein G Sepharose-coated beads was added to the antibody-lysate mixture and incubated for an additional $2 \mathrm{~h}$. The beads were then washed 4 times in 1 $\mathrm{ml}$ lysis buffer, resuspended, and centrifuged for $1 \mathrm{~min}$ at $1000 \mathrm{rpm}$ each time. The beads were eluted by adding $60 \mu \mathrm{l}$ of nonreducing SDS buffer and heating at $95^{\circ} \mathrm{C}$ for $10 \mathrm{~min}$. hnRNP $\mathrm{H}$ immunoprecipitates were eluted in nonreducing SDS buffer as described above; $50 \mu \mathrm{l}$ of each sample was separated by SDS-PAGE at $100 \mathrm{~V}$ for $30 \mathrm{~min}(\sim 2 \mathrm{~cm})$ on a Novex Bolt $4 \%-12 \%$ Bis-Tris gel. The gel was then washed 3 times in deionized $\mathrm{H}_{2} \mathrm{O}$ and stained with Simply Blue Coomassie SafeStain (Thermo Fisher Scientific, catalog \#LC6060). The gel was then cut at $\sim 160 \mathrm{kDa}$ to exclude the prominent nonreduced IgG band. Individual gel lanes were then separately excised and stored in prewashed microcentrifuge tubes at $4^{\circ} \mathrm{C}$ before shipping to the University of Massachusetts Worchester Proteomics and Mass Spectrometry facility for analysis by OrbiTrap liquid chromatography tandem mass spectrometry (LC-MS/MS).

\section{TMT labeling, high $\mathrm{pH}$ reverse phase HPLC fraction, followed by $L C-M S / M S$}

Following the $3 \mathrm{~d}$ locomotor paradigm assessing acute locomotor sensitivity in $\mathrm{H}^{+/-}$versus WT mice as described above, striata were dissected from the mice at $30 \mathrm{~min}$ after injection. Synaptosomes were isolated following the procedure outlined above for proteomic characterization. Samples were resuspended in $8 \mathrm{~m}$ urea for $30 \mathrm{~min}$, followed by the addition of $5 \mathrm{~mm}$ DTT for $1 \mathrm{~h}$. Lodoacetamide was then add to the samples that were incubated in the dark for $30 \mathrm{~min}$. The urea concentration was diluted $<1 \mathrm{~m}$ with the addition of $50 \mathrm{~mm}$ of ammonium bicarbonate. The samples were then digested with trypsin (50:1, protein to enzyme ratio) overnight at $37^{\circ} \mathrm{C}$ and terminated with the addition of formic acid to $1 \%$. The samples were desalted with a C18 tip. Peptide was determined by Pierce Quantitative Colorimetric Assay (Thermo Fisher Scientific, cata$\log \# 23275$ ); then $100 \mu \mathrm{g}$ of peptide was resuspended in $0.1 \mathrm{M}$ triethylammonium bicarbonate and incubated with the TMT plex isobaric labeling for $1 \mathrm{~h}$ at room temperature. To quench the reaction, $5 \%$ hydroxylamine was added to each sample and incubated for $15 \mathrm{~min}$. Each sample was combined at equal amount and cleaned with C18 tips. One milligram of labeled peptides was fractioned using a Waters XBridge BEH C18 $(3.5 \mu \mathrm{m}, 4.6 \times 250 \mathrm{~mm})$ column on an Agilent Technologies 1100 HPLC system. A total of 48 fractions were collected and combined to 12 fractions and then dried. A C18 Acclaim PepMap 100 precolumn $(3 \mu \mathrm{m}, 100 \AA, 75 \mu \mathrm{m} \times 2 \mathrm{~cm}$ ) hyphenated to a PepMap RSLC C18 analytical column $(2 \mu \mathrm{m}, 100 \AA, 75 \mu \mathrm{m} \times 50 \mathrm{~cm})$ was used to separate peptide mixture. LC-MS/MS analyses were completed using an EASY nLC 1200 system coupled to a Q Exactive HF-X mass spectrometer. Full MS spectra were collected at a resolution of 120,000 with an AGC of $3 \times$ $10^{6}$ or maximum injection time of $50 \mathrm{~ms}$ and a scan range of 350 to 1650 $\mathrm{m} / \mathrm{z}$. MS2 scans were performed at 45,000 resolution and using $32 \%$ total
A

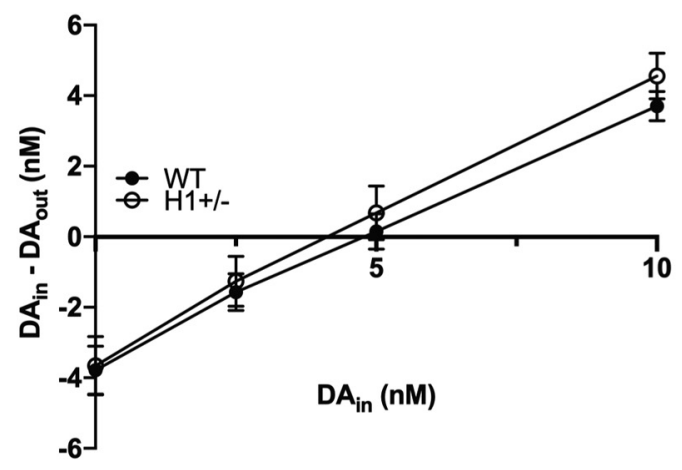

B

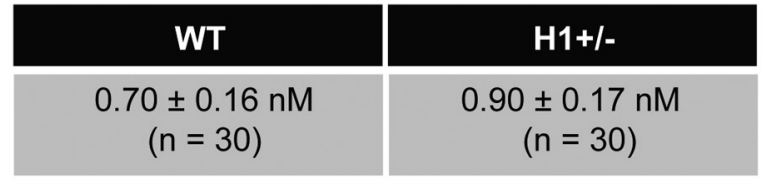

C

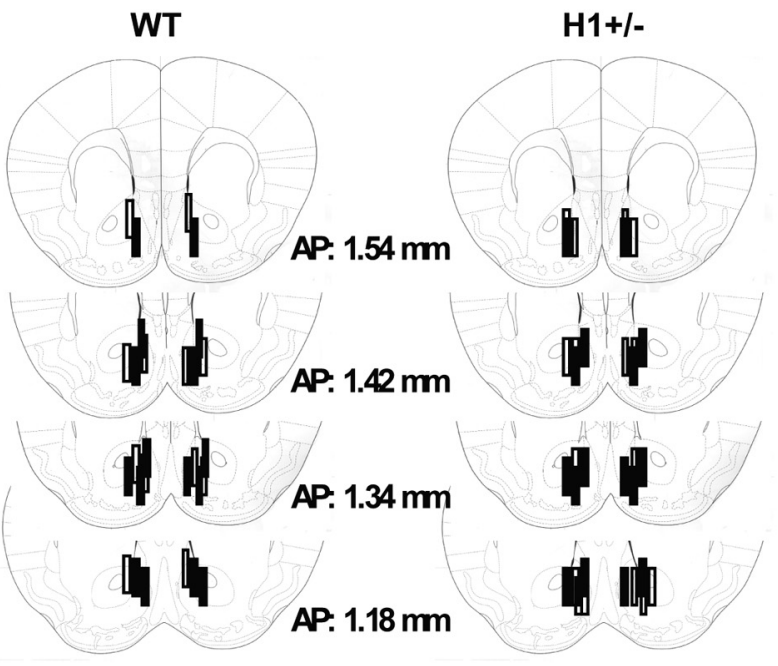

Figure 10. DA no net flux, baseline DA levels, and probe placements in $\mathrm{H}^{+/-}$mice. $A, \mathrm{DA}$ no net flux in $\mathrm{H}^{+/-}$and WT mice revealed no genotypic difference at the point of no DA flux within the NAc: $y=0: 5.00 \pm 0.44$ for WT $(n=16)$ versus $4.68 \pm 0.70$ for H1 ${ }^{+/-}(n=16)$. These data do not support an effect of Hnrnph1 deletion on basal extracellular DA content $(y=$ 0 ) or basal DA release/reuptake (extraction fraction) associated with the reduced MA-induced $D A$ release observed in $\mathrm{H}^{+/-}$mice. $\boldsymbol{B}$, Summary of the average extracellular DA content $(\mathrm{nm}) \pm$ SEM before an acute injection of MA in WT and $\mathrm{H} 1^{+/-}$mice. There was no genotypic difference in the average basal extracellular DA content, before MA injection. Sample sizes are indicated in parentheses. C, Probe placements for WT and $\mathrm{H}^{+/-}$mice fall primarily within the NAc shell (bregma: 1.54 to $1.18 \mathrm{~mm}$ ).

normalized collision energy. Source ionization parameters were optimized with the spray voltage at $2.1 \mathrm{kV}$; dynamic seclusion was set to $45 \mathrm{~s}$.

\section{Proteomics data analysis and pathway enrichment results}

The acquired data were searched by MaxQuant against the UniProt mouse proteome database with standard settings (fragment ion mass tolerance of $20 \mathrm{ppm}$, maximum missed cleavage of 2 , oxidation as variable modification, false discovery was $1 \%$, only protein groups identified with at least 2 or more peptides). The intensity data were filtered and normalized using R (RRID:SCR_001905) and the LIMMA package (RRID:SCR_010943) was used for differential analysis with Genotype and Treatment as factors. A ranked list was generated from the analysis, and the fgsea $\mathrm{R}$ package was used to perform preranked analysis, with proteins filtered for absolute $\log _{2} \mathrm{FC}>0.2$ and $p<0.05$. Enrichment results for the comparisons were visualized using Cytoscape (RRID: SCR_003032) and EnrichmentMap (RRID:SCR_016052), with nodes representing pathways and edges representing overlap genes. Pathways 
were clustered and annotated with themes using AutoAnnotate (Reimand et al., 2019).

Experimental design and

statistical analyses

Characterization of Hnrnph1/2 gene expression and hnRNP $H$ protein expression in $H 1^{+/-}$mice. For gene expression analysis of Hnrnph1/2 via qPCR, each sample was run in triplicate and averaged. Differential gene expression was reported as the fold change in $\mathrm{H} 1^{+/-}$and $\mathrm{H} 1^{-1-}$ relative to WT littermates using the $2^{-\left(\Delta \Delta \mathrm{C}_{\mathrm{T}}\right)}$ method (Livak and Schmittgen, 2001). To examine genotypic differences in transcript and protein expression among $\mathrm{WT}, \mathrm{H}^{+/-}$, and $\mathrm{H} 1^{-/-}$, one-way ANOVA was conducted. To examine genotypic difference in level of peptides unique to either hnRNP H1 or hnRNP H2, two-tailed unpaired $t$ test was performed for each peptide, with the exception of Peptide 3 for hnRNP H1, where we used a one-tailed unpaired $t$ test based on a priori results published by Yazdani et al. (2015), indicating a decrease in exon 4 usage of Hnrnph1 in the $\mathrm{H} 1^{+/-}$versus WT. Thus, we hypothesized that Peptide 3 , which is encoded by part of exon 4, would also be decreased in the $\mathrm{H} 1^{+/-}$mice.

Oral self-administration. To determine the effects of the $\mathrm{H1}^{+/-}$mutation upon MA reinforcement and intake, an operantconditioning procedure was used, and the data for the mean number of active nose pokes, inactive nose pokes, and MA intake compared between $\mathrm{WT}$ and $\mathrm{H} 1^{+/-}$mice. This comparison was evaluated using mixed-model ANOVA with the between-subjects factors of Genotype and Sex and the within-subjects factor of MA concentration $(80,120,160,200,300$, and 400 $\mathrm{mg} / \mathrm{L}$ ). In a follow-up study, WT and $\mathrm{H} 1^{+/-}$ mice were trained to self-administer the 200 $\mathrm{mg} / \mathrm{L}$ MA concentration over the course of $14 \mathrm{~d}$. The data for this study were analyzed using mixed-model ANOVA with Genotype and Sex as between-subjects factors and day as the repeated measure (days 1-14). To interrogate potential genotypic differences in bitter tastant sensitivity, the dose-response function for quinine intake was determined in a separate cohort of mice, and the data were analyzed using a mixed-model ANOVA with between-subjects factors of Genotype and Sex and repeated measures on the Quinine Concentration factor $(0.003,0.01,0.03,0.1$, 0.3 , and $0.6 \mathrm{mg} / \mathrm{ml})$.

In vivo microdialysis. To relate genotypic differences in behavior to changes in extracellular DA and glutamate within the NAc, we conducted a series of in vivo microdialysis experiments. The first series of experiments used no net flux microdialysis procedures, and the ensuing dose-response data were analyzed by linear regression to determine the extraction fraction/clearance of the neurotransmitter (determined by the slope of the regression) and the basal neurotransmitter content (determined by $x=0$ from the regression). The extraction fraction and content were analyzed by a univariate ANOVA with the between-subjects factors of Sex and Genotype. The second series of experiments examined the time course of MAinduced changes in extracellular DA, 3,4-dihydroxyphenylacetic acid (DOPAC), and glutamate. The average baseline neurotransmitter content for the $60 \mathrm{~min}$ before MA injection was analyzed using a univariate $2 \mathrm{mg} / \mathrm{kg}$ MA for WT.
MA-induced DA release: 0.5 and $2 \mathrm{mg} / \mathrm{kg}$ (i.....).

B
$2 \mathrm{mg} / \mathrm{kg}$

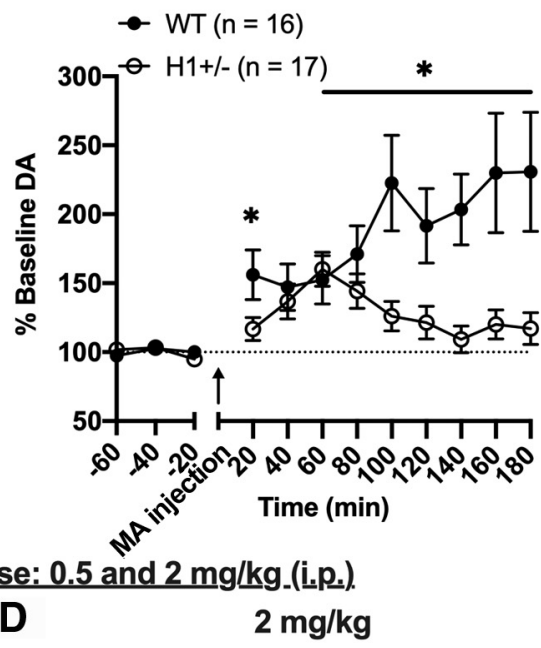

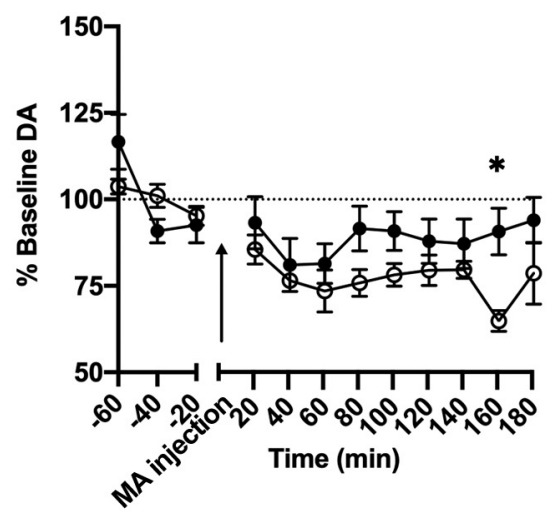

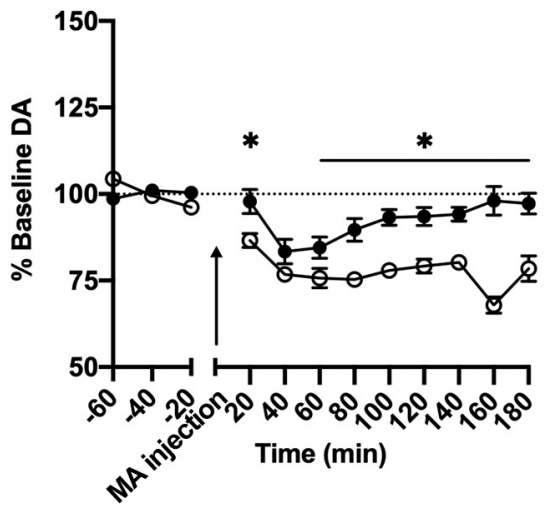

Figure 11. In vivo microdialysis of $\mathrm{MA}$-induced $\mathrm{DA}$ release in $\mathrm{H} 1^{+/-}$mice. $\mathrm{H} 1^{+/-}$mice showed blunted $\mathrm{MA}$-induced $\mathrm{DA}$ and DOPAC levels compared with WT. Mice were probed on the contralateral side, perfused with aCSF, and administered an MA challenge of either $0.5 \mathrm{mg} / \mathrm{kg}$ or $2 \mathrm{mg} / \mathrm{kg}$ (i.p., black arrow) after a $1 \mathrm{~h}$ baseline period. $\boldsymbol{A}, \boldsymbol{B}$, The capacity of MA to elevate DA in the NAc was blunted in the $\mathrm{H}^{+/-}$mice, in a manner that varied with the dose of MA administered. $A$, The $0.5 \mathrm{mg} / \mathrm{kg} \mathrm{MA} \mathrm{dose} \mathrm{elicited}$ an increase in extracellular DA in in WT but not in $\mathrm{H}^{+/-}$mice, with $\mathrm{H}^{+1-}$ mice exhibiting significantly lower extracellular DA levels than WT mice at all time points after injection (unpaired $t$ test for each time point for WT vs $\mathrm{H}^{+/-}$: for time $=20$ to 180 $\mathrm{min}) .{ }^{*} p<0.033$. $\boldsymbol{B}$, The $2 \mathrm{mg} / \mathrm{kg}$ MA dose elicited an increase in extracellular DA in both genotypes; however, the temporal patterning and the magnitude of this rise was distinct between $\mathrm{H}^{+/-}$and WT mice. $\mathrm{H}^{+/-}$mice exhibited lower DA levels compared with WT mice during the first $20 \mathrm{~min}$ after injection, as well as during the second half of testing (unpaired $t$ test for each time point for WT vs $\mathrm{H}^{+/-}$: for time 20,60, to $180 \mathrm{~min}$ ). ${ }^{*} p<0.05$. C, D, MA dose-dependently reduced NAc extracellular DOPAC levels; however, regardless of MA Dose or Sex, this reduction was, overall, greater in $\mathrm{H} 1^{+/-}$versus WT mice. C, MA $(0.5 \mathrm{mg} / \mathrm{kg})$ induced a lowering of extracellular DOPAC, relative to baseline levels, with $\mathrm{H}^{+/-}$mice exhibiting significantly lower DOPAC 80 min after injection (unpaired $t$ test for each time point for WT vs $\mathrm{H}^{+/-}$: for time $\left.=160 \mathrm{~min}\right) .{ }^{*} p=0.03 . D, \mathrm{MA}(2 \mathrm{mg} / \mathrm{kg})$ induced a lowering of extracellular DOPAC in both genotypes; however, the effect was amplified in $\mathrm{H}^{+/-}$mice. Relative to WT animals, $\mathrm{H} 1^{+/-}$mice exhibited lower DA levels during the first 20 min after injection, as well as during the second half of testing (unpaired $t$ test for each time point for WT vs $\mathrm{H}^{+1-}$ : for time 20 and 60 to 180 ). ${ }^{*} p<0.05 . n=13$ (7 females, 6 males) at 0.5 and $n=17$ (10 females, 7 males) at $2.0 \mathrm{mg} / \mathrm{kg} \mathrm{MA} \mathrm{for} \mathrm{H1}^{+/-} ; n=14$ (8 females, 6 males) at $0.5 \mathrm{mg} / \mathrm{kg} \mathrm{MA}$ and 17 (10 females, 7 males) at

ANOVA along the between-subjects factors of Genotype and Sex. Mice were slated to receive one of two MA doses $(0.5$ and $2.0 \mathrm{mg} / \mathrm{kg}$ ), and the data for each neurotransmitter were expressed as a percent change from the average baseline and analyzed using a mixed-model ANOVA with Genotype and Sex as between-subjects factors and repeated measures on the Time factor (12, $20 \mathrm{~min}$, bins), separately for each MA dose.

$C P P$. To examine genotypic differences in MA reward, we assessed MA-CPP by quantifying the change in time spent on drug-paired side on day 8 - day 1 or on day 9 - day 1 . Preference was analyzed using a three-way ANOVA with Genotype, Sex, and Treatment (saline, 0.5 $\mathrm{mg} / \mathrm{kg} \mathrm{MA}$, and $2 \mathrm{mg} / \mathrm{kg} \mathrm{MA}$ ) as between-subjects factors. Because this analysis indicated genotype- and dose-dependent change in MA-CPP, 


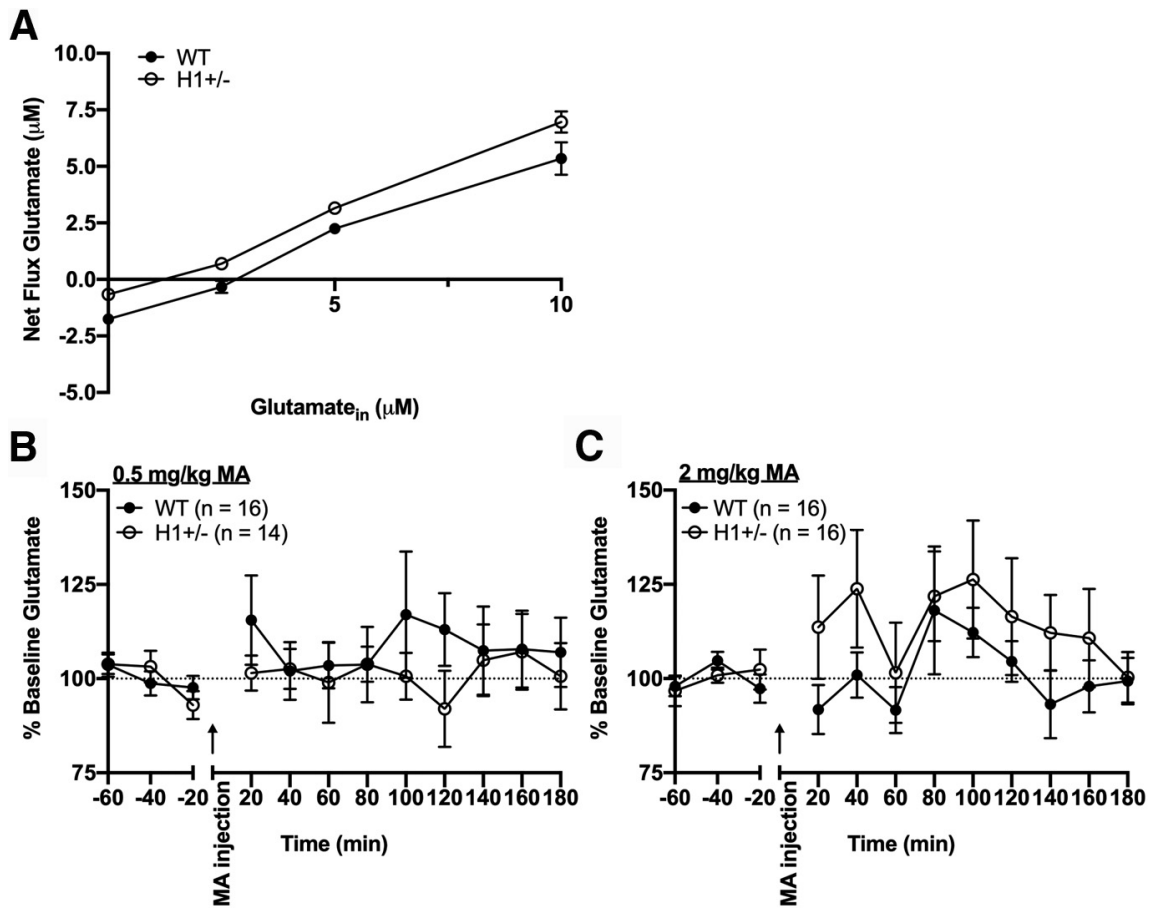

Figure 12. In vivo microdialysis of MA-induced glutamate release in $\mathrm{H}^{+/-}$mice. $\boldsymbol{A}$, Linear regression analyses of the results of a glutamate no net flux in vivo microdialysis study $(0,2.5,5$, and $10 \mu \mathrm{m}$ glutamate) revealed no genotypic differences in the $x$ intercept (an estimate of basal extracellular glutamate content in $\mu \mathrm{m} ; \mathrm{WT}: 2.28 \pm 0.56, n=7 \mathrm{vs} \mathrm{H} 1^{+/-}: 2.55 \pm 0.18, n=8$ ) and no difference in the extraction fraction or slope of the regression (an index of neurotransmitter release/clearance; WT: $0.73 \pm 0.07$ vs $\left.\mathrm{H} 1^{+/-}: 0.80 \pm 0.04\right) . B, C$, No genotypic or sex differences were detected in average baseline extracellular glutamate levels, determined under conventional in vivo microanalysis procedures (WT $=3.27 \pm 0.39 \mu \mathrm{M}, n=32 \mathrm{vs} \mathrm{H} 1^{+1-}=3.67 \pm 0.32 \mu \mathrm{m}$, $n=30$ ). Data are expressed as the percent change from the average baseline value to better visualize the time course of the glutamate response to an acute injection of $(\boldsymbol{B}) 0.5$ or $(\boldsymbol{C}) 2 \mathrm{mg} / \mathrm{kg} \mathrm{MA}$.

we ran two-tailed unpaired $t$ tests at each dose to identify genotypic differences in MA-CPP. To assess potential genotypic differences in MAinduced locomotor activity in the smaller arena containing the textured floor that comprised the MA-CPP side (days 2-5) as well as in the entire arena (days 1,8 , and 9), we analyzed distance traveled in $5 \mathrm{~min}$ bin using a mixed-effects ANOVA with Genotype, Sex, and Treatment (saline, 0.5 $\mathrm{mg} / \mathrm{kg}$, or $2 \mathrm{mg} / \mathrm{kg} \mathrm{MA}$ ) as between-subjects factors and repeated measures on Time (12, $5 \mathrm{~min}$ bins), separately for each day. Two-tailed unpaired $t$ tests were used to determine the sources of main effects of Genotype and Treatment and interactions with Time.

Behavioral test battery. To determine the effects of Genotype upon sensorimotor function and affect, WT and $\mathrm{H}^{+/-}$mice were subjected to a behavioral test battery consisting of prepulse inhibition, the novel object test, marble-burying, light-dark shuttle-box, Porsolt swim test, and motor coordination on a rotarod. The data generated from these assays were analyzed using two-tailed unpaired $t$ tests.

Quantification of DA content and MA metabolites and DAT-mediated $D A$ uptake. To determine whether there was a genotypic difference in DA content at baseline and MA metabolite after MA injection, a two-tailed unpaired $t$ test was performed. In examining whether there is an MAinduced change on DAT-mediated DA uptake between WT and $\mathrm{H} 1^{+/-}$ mice, a two-way ANOVA with Genotype and Treatment (saline and MA) as between-subjects factors was used.

MA-induced locomotor activity assessment before tissue collection for mass spectrometry. To replicate the reduction in MA-induced locomotor activity in $\mathrm{H}^{+/-}$mice that we previously observed under identical conditions (Yazdani et al., 2015), we examined total distance traveled in 5 min bin, separately for days 1-3 via mixed-effects ANOVA with Genotype, Sex, and Treatment (saline and $2 \mathrm{mg} / \mathrm{kg} \mathrm{MA}$ ) as between-subjects factors and Time as the repeated-measures factor. Two-tailed unpaired $t$ tests were used to determine sources of the main effects of Genotype and interactions with Time.
Immunoblotting and IHC. To examine the effect of Genotype on $\mathrm{TH}$ protein expression via immunoblotting and IHC, two-tailed unpaired $t$ test was performed on loading controlnormalized data between WT and $\mathrm{H}^{+/-}$. To determine whether there was an effect of Sex on DAT protein expression, two-way ANOVA with Genotype and Sex as betweensubjects factors was conducted. Two-tailed unpaired $t$ tests were used to determine sources of the main effects of Sex and interactions with Genotype.

To examine MA-induced changes in protein expression, including DAT, hnRNP $\mathrm{H}$, and mitochondrial proteins, two-way ANOVA with Genotype and Treatment as between-subjects factors was conducted. For hnRNP H expression in the synaptosome, the significant main effect of Genotype was followed up with twotailed unpaired $t$ tests to examine differences between WT and $\mathrm{H}^{+/-}$.

For all behavioral studies, we used an effect size of Cohen's $d=0.9$ to guide our sample size based on genotypic differences in MA-induced locomotor activity at $30 \mathrm{~min}$ after MA in our previously published data from $\mathrm{H}^{+/-}$mice (Yazdani et al., 2015). We used $\mathrm{G}^{\star}$ Power 3 (Faul et al., 2007) to calculate a sample size of $n=16$ per genotype required for $80 \%$ power $(p<0.05)$. All behavioral studies used both male and female mice. All data are presented as means of replicates from each experiment \pm SEM. In summary, for experiments in which two conditions were compared, a two-tailed unpaired $t$ test was used to analyze the data unless otherwise specified. For experiments in which multiple factors were evaluated, ANOVA was used and significant interaction was deconstructed along the relevant factor to examine main effects and group differences followed up using $t$ tests. Statistical $p$ value threshold for $t$ test and ANOVA was set to 0.05. The data comprising oral selfadministration in vivo microdialysis were analyzed in SPSS version 21 (IBM). All other data were analyzed in R (RRID:SCR_001905).

Data and code availability

All related data and materials are available upon request. The mass spectrometry proteomics data are available in MassIVE under proteome exchange accession number PXD014813.

\section{Results}

Characterization of Hnrnph1/2 gene expression and hnRNP H protein expression in $\mathrm{H} 1^{+/-}$mice

Hnrnph1 mutant mice $\left(\mathrm{H}^{+/-}\right)$were generated using transcription activator-like effector nucleases targeting the first coding exon of Hnrnph1 (exon 4, UCSC Genome Browser). Deletion of a small region in the first coding (exon 4) in Hnrnphl leads to a premature stop codon and transcription of a truncated mRNA message. The mice were genotyped using a restriction enzymebased assay (Fig. 1A) (Yazdani et al., 2015). Gene expression via qPCR with primers specific for exons 6 and 7 (not targeting the deleted exon 4) detected a 50\% increase of Hnrnph1 transcript in the $\mathrm{H} 1^{+/-}$(heterozygous for deletion) relative to WT (Yazdani et al., 2015) and a 1.5-fold increase in the $\mathrm{H}^{-1-}$ (homozygous for deletion) (Fig. $1 B$; one-way ANOVA, $F_{(2,9)}=2.55, p=0.133$; pairwise comparison between WT vs $\mathrm{H1}^{-1-}: t_{(6)}=-2.82, p=$ $0.031 ; n=4$ per group) with no change in gene expression of Hnrnph2 (Yazdani et al., 2015; Fig. $1 C$; one-way ANOVA, $F_{(2,9)}=$ 
A

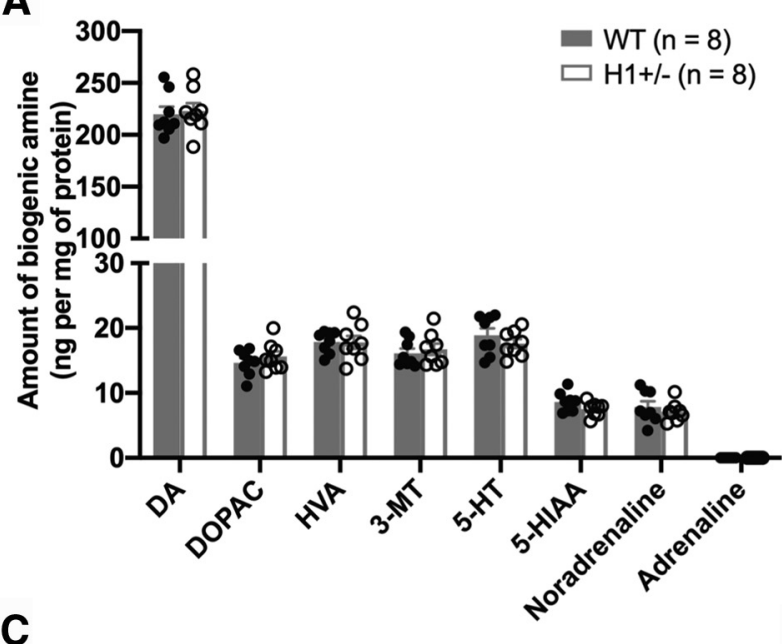

C

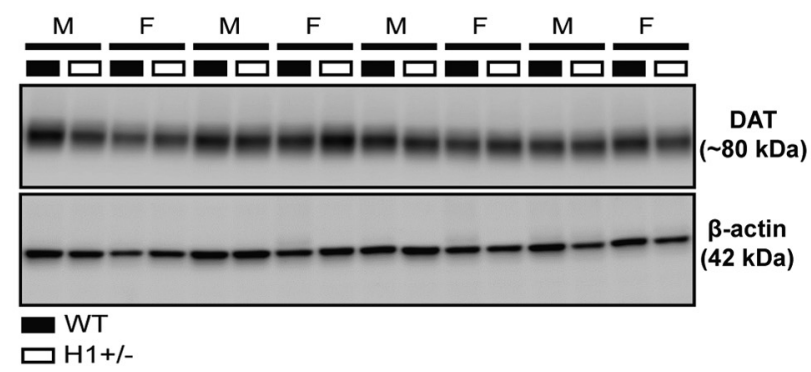

$\mathbf{E}$

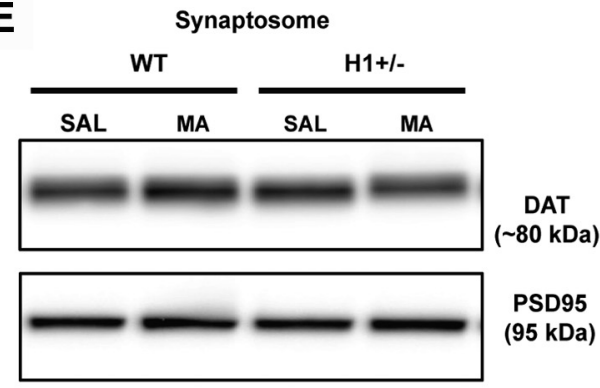

B

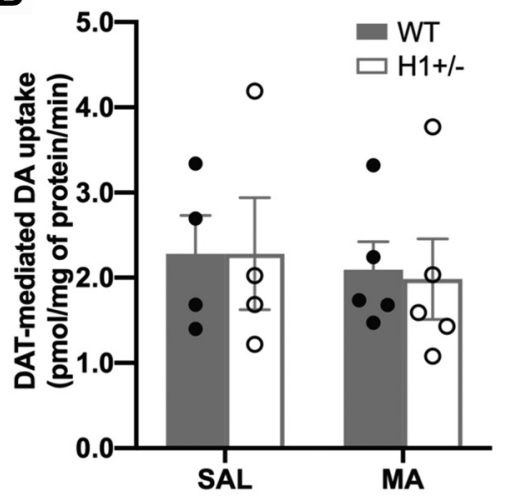

D

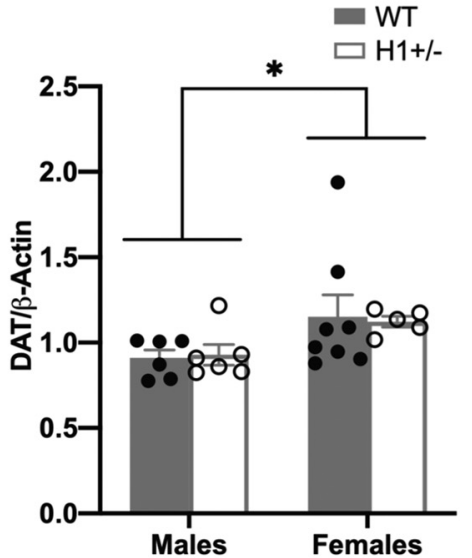

$\mathbf{F}$

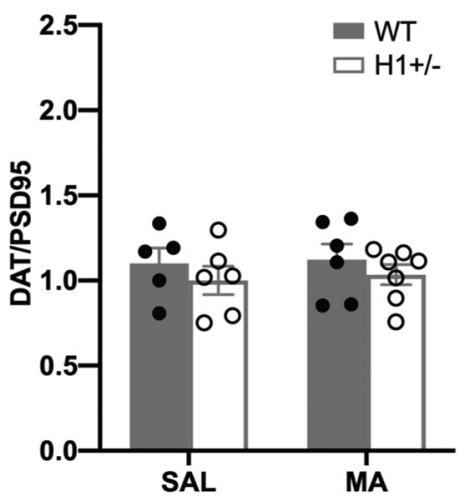

Figure 13. DA content and uptake and DAT levels in the striatum of $\mathrm{H}^{+/-}$mice. No changes in DA or in DAT were detected at baseline in the striatum of $\mathrm{H} 1^{+/-}$mice compared with WT mice. $A$, Measurement of biogenic amine content in the striatum showed no difference in the level of DA between $\mathrm{H}^{+/-}$and WT mice. $\mathrm{H} 1^{+/-}$also exhibited no change in the levels of other biogenic amines. $n=8$ per genotype. $B$, DAT-mediated DA uptake in the striatum of $\mathrm{H}^{+/-}$mice. Striatum was harvested at $2 \mathrm{~h}$ after saline or MA injection for DA uptake assay, based on the time course of the microdialysis data in Figure 10. There was no genotypic difference in the rate of DA uptake in response to saline (SAL) or MA. C, D, Immunoblot for DAT level in the striatum. Representative immunoblot for DAT shown in $\boldsymbol{C}$ with quantification shown in $\boldsymbol{D}$. There was no change in DAT protein level in the striatum of $\mathrm{H}^{+/-}$relative to WT mice. There was a main effect of Sex that was explained by females showing a higher level of DAT compared with that of male mice (female, $n=13 ;$ male, $n=12$ ). ${ }^{*} p=0.02$ (unpaired $t$ test for females vs males). $E$, Immunoblot showing DAT protein level in the striatal synaptosome at $30 \mathrm{~min}$ after saline (SAL) or MA treatment. $\boldsymbol{F}$, The striatal synaptosome of $\mathrm{H}^{+}{ }^{+-}$mice did not show any change in DAT relative to WT mice after SAL or MA treatment.

$1.28, p=0.324 ; n=4$ per group). At the protein level, there was no change in hnRNP $\mathrm{H}$ protein expression in $\mathrm{H}^{+/-}$or $\mathrm{H} 1^{-/-}$ embryonic stage brain tissue homogenate (Fig. $1 D-G$; one-way ANOVA, $\mathrm{C}$ terminus: $F_{(2,9)}=0.89, p=0.440 ; \mathrm{N}$ terminus: $F_{(2,9)}=$ $1.64, p=0.250 ; n=4$ per group). Because hnRNP H1 and H2 have $96 \%$ amino acid sequence homology, there is no commercially available antibody that can differentiate the two proteins. Quantitative analysis of protein peptide from an hnRNP H im- munoprecipitation mass spectrometry study identified no difference in peptide level unique to hnRNP $\mathrm{H} 1$ between the $\mathrm{H} 1^{+/-}$ mice compared with that of WT (Fig. $2 A, B$; unpaired $t$ test for each individual peptide, Peptide $1: t_{(4)}=-0.45, p=0.673$; Peptide 2: $t_{(4)}=-1.39, p=0.236$; Peptide $3: t_{(4)}=-1.94, p=0.125$; Peptide 4: $t_{(4)}=-0.85, p=0.445$; Peptide $5: t_{(4)}=-1.06, p=$ 0.351; Peptide 6: $t_{(4)}=0.46, p=0.672$; Peptide 7: $t_{(4)}=2.21, p=$ 0.091; Peptide 8: $t_{(4)}=-1.07, p=0.346 ; n=3$ per group). 


\section{A Bregma $-3.28 \mathrm{~mm}$ to $-3.64 \mathrm{~mm}$}

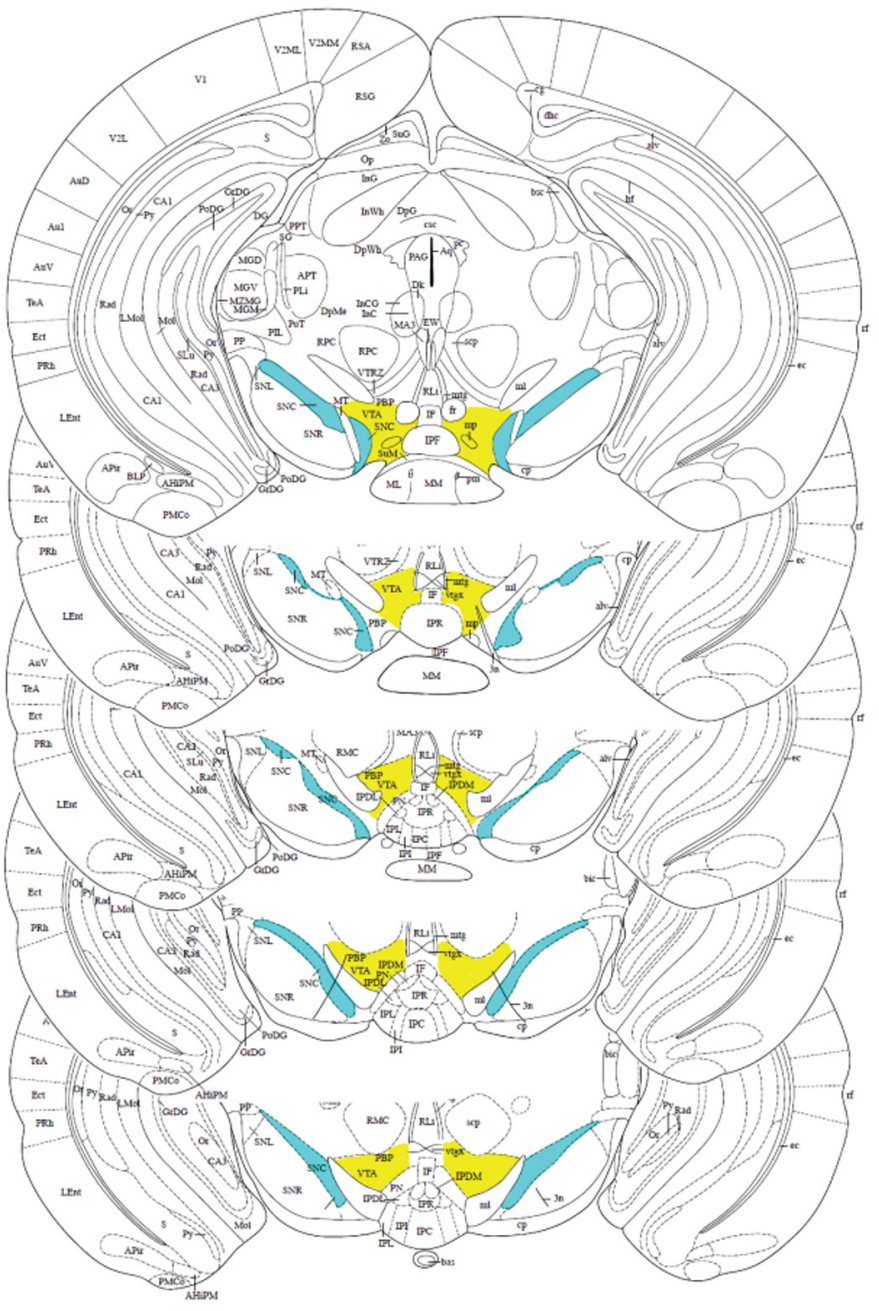

\section{B $\quad$ Bregma $1.18 \mathrm{~mm}$ to $0.86 \mathrm{~mm}$}

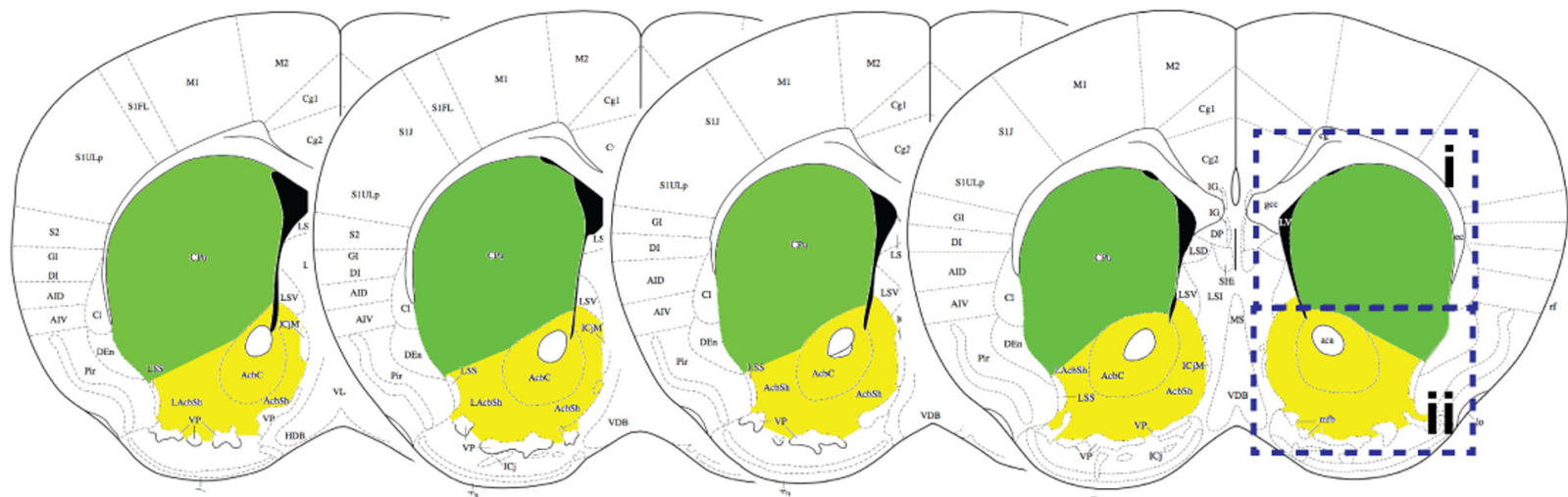

Figure 14. Schematics showing bregma positions of the brain regions in IHC studies and Western blots. $A$, VTA and SNc of midbrain. Left, Schematic showing the ventral midbrain region dissected for Western blot analysis. Right, Coronal brain diagrams showing highlighted VTA (yellow) and SNC (teal) for IHC. B, Coronal brain diagrams showing highlighted dorsal striatum (green) and NAC (yellow) for IHC.

Because we previously detected a decrease in transcription of exon 4 in the $\mathrm{H}^{+/-}$mice (Yazdani et al., 2015) (Fig. 1B), we hypothesized that there would be a decrease in the level of Peptide 3 (GLPWSCSADEVQR), which contains amino acid residues en- coded by the deleted region in exon 4 of Hnrnph1. Indeed, there was a decrease in the level of Peptide 3 in $\mathrm{H} 1^{+/-}$mice, although this result did not reach statistical significance (Fig. $2 A, B$; onetailed unpaired $t$ test, $t_{(4)}=-1.94, p=0.062$ ). No genotypic 
difference was observed in unique peptides associated with hnRNP H2 (Fig. $2 C, D$; unpaired $t$ test for each individual peptide, Peptide 1: $t_{(4)}=-0.83, p=$ 0.454; Peptide 2: $t_{(4)}=0.86, p=0.441$; Peptide 3: $t_{(4)}=1.56, p=0.197$; Peptide 4: $t_{(4)}=0.95, p=0.396$; Peptide 5: $t_{(4)}=$ $-0.516, p=0.633$; Peptide 6: $t_{(4)}=$ $-0.07, p=0.950 ; n=3$ per group).

\section{Oral MA self-administration}

We previously demonstrated a robust reduction in sensitivity to the locomotor stimulant response to $\mathrm{MA}$ in $\mathrm{H}^{+/-}$ mice (Yazdani et al., 2015). To more directly test MA-induced motivated behaviors, we investigated MA reinforcement and intake in $\mathrm{H}^{+/-}$mice using an oral MA self-administration paradigm as conducted previously in C57BL/6J mice (Szumlinski et al., 2017). This study showed that mice allocated the majority of their nose-poking behavior toward the MA-reinforced hole, indicating drug reinforcement. $\mathrm{H}^{+/-}$mice presented fewer active nose pokes at the 160, 200, 300, and $400 \mathrm{mg} / \mathrm{L} \mathrm{MA}$ doses compared with WT mice (Fig. $3 A$; mixedeffects ANOVA, $F_{(1,41) \text { Genotype }}=6.33, p=$ $0.02 ; F_{(5,205) \text { Dose }}=23.93, p<0.0001$; $F_{(5,205) \text { Genotype } \times \text { Dose }}=1.58, p=0.166$; unpaired $t$ tests for 80 and $120 \mathrm{mg} / \mathrm{L}, p$ values $>0.65$; for $160-400 \mathrm{mg} / \mathrm{L}, \quad p$ values $<0.03$; WT: $n=22$ and $\mathrm{H}^{+/-}: n=23$ ), with no difference in nonspecific, inactive nose pokes across a range of MA concentrations $(80-400 \mathrm{mg} / \mathrm{L}$ ) (Fig. 3B; mixedeffects ANOVA, $F_{(1,41) \text { Genotype }}=0.76, p=$ $0.39 ; F_{(5,205) \text { Dose }}=5.84, p<0.0001$; $\left.F_{(5,205) \text { Genotype } \times \text { Dose }}=1.27, p=0.28\right)$. Consistent with their lower level of MA reinforcement, $\mathrm{H}^{+/-}$mice also consumed less MA (intake; mg/kg/d) at the 200,300 , and $400 \mathrm{mg} / \mathrm{L}$ concentrations (Fig. 3C; mixed-effects ANOVA, $F_{(1,41) \text { Genotype }}=6.85, p=$ $0.01 ; F_{(5,205) \text { Dose }}=52.11, p<0.0001$; $F_{(5,205) \text { Genotype } \times \text { Dose }}=4.47, p<0.0001$; unpaired $t$ tests for $80-160 \mathrm{mg} / \mathrm{L}, p$ values $>0.12$; for $200-400$ $\mathrm{mg} / \mathrm{L}, p$ values $<0.03)$. These results indicate that the $\mathrm{H} 1^{+/-}$ mice are less motivated to work for the MA reinforcer. No interactions between Sex and Genotype were observed for any measure during self-administration testing (mixed-effects ANOVAs for active and inactive hole pokes and for MA intake, $F_{(1,41) \operatorname{Sex} \times \text { Genotype }}$ $<2.83$, $p$ values $>0.10 ; F_{(5,205) \text { Genotype } \times \text { Sex } \times \text { Dose }}<1.63, p$ values $>0.15)$. The genotypic differences in high-dose MA intake did not relate to bitter taste sensitivity as quinine intake in the home cage was equivalent between $\mathrm{H}^{+/-}$and WT mice (Fig. 4; mixed-effects ANOVA, $F_{(5,100) \text { Quinine }}=44.63, p<0.0001$; $F_{(1,20) \text { Genotype }}=2.07, p=0.170 ; F_{(5,100) \text { interaction }}=0.50, p=$ $0.780)$.

The blunted escalation of oral MA intake observed at high MA concentrations $(\geq 200 \mathrm{mg} / \mathrm{L})$ in $\mathrm{H}^{+/-}$mice initially trained to

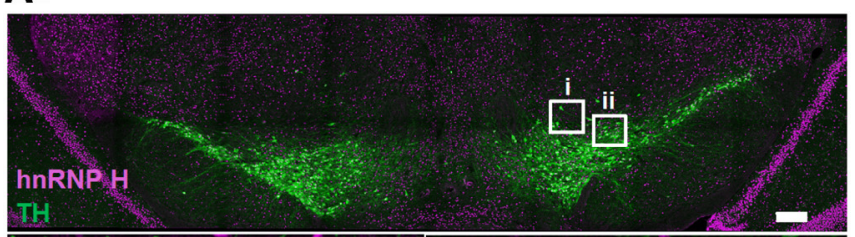

B

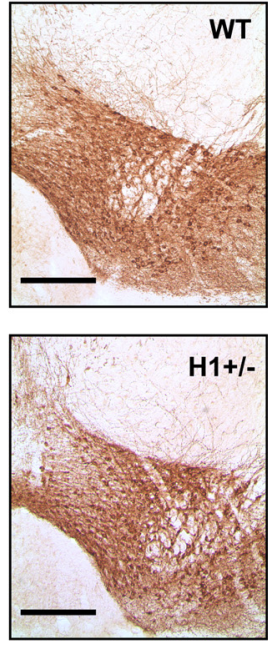

E
D
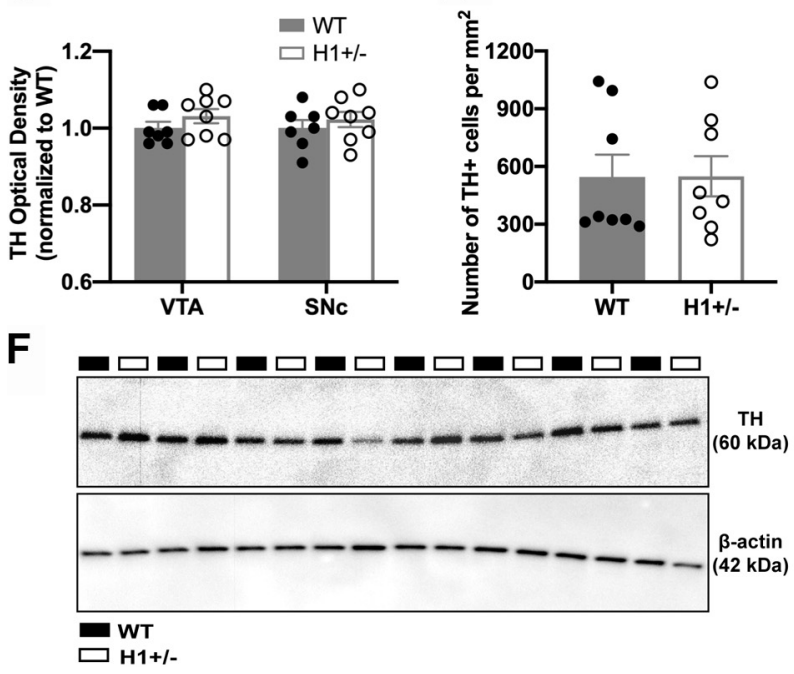

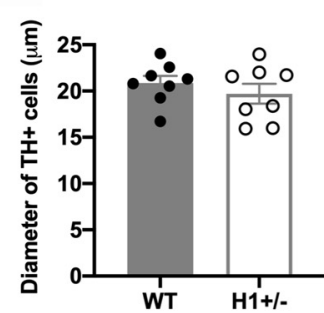

G

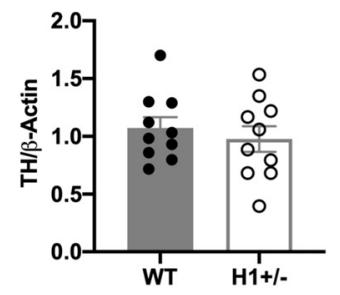

Figure 15. THlevels in the midbrain of $\mathrm{H} 1^{+/-}$mice. No difference in TH level was detected in the VTA between $\mathrm{H} 1^{+/-}$and WT mice. $\boldsymbol{A}$, Immunofluorescent staining of hnRNP H (magenta) and TH (green) was conducted in coronal midbrain sections (bregma: images demonstrate nuclear expression of hnRNP H across all TH-positive dopaminergic neurons that we examined. Scale bars: , $200 \mu \mathrm{m}$; bottom, $20 \mu \mathrm{m}$. B , Representative image showing immunohistochemical DAB staining of TH in coronal sections of 列 in the diameter of TH-positive cells $(\boldsymbol{E})$. WT: $n=8 ; \mathrm{H}^{+/-}: n=8 . \boldsymbol{F}, \mathbf{G}$, Immunoblot for TH protein level in the midbrain. Representative immunoblot for TH shown $(\boldsymbol{F})$ and quantification $(\boldsymbol{G})$. There was no change in TH protein level in the midbrain region of $\mathrm{H} 1^{+/-}$relative to WT mice. WT: $n=10 ; \mathrm{H} 1^{+/-}: n=10$.

respond for $80 \mathrm{mg} / \mathrm{L} \mathrm{MA}$ prompted us to determine whether the Hnrnph1 mutation would blunt the acquisition of oral MA selfadministration when $200 \mathrm{mg} / \mathrm{L}$ MA served as the reinforcer. However, we were unable to detect any genotypic difference in MA intake and active nose pokes when mice were trained at this higher MA concentration (Fig. 5; mixed-effects ANOVA, $F_{(13,273) \text { day }}=8.39, p<0.0001 ; F_{(1,21) \text { Genotype }}=0.01, p=0.91$; $\left.F_{(13,273) \text { Genotype } \times \text { day }}=0.39, p=0.97\right)$. These results indicate that the Hnrnph1 mutation interferes with the transition from low- to high-dose MA self-administration, without altering the reinforcing effects of MA during acquisition.

\section{MA-conditioned reward}

To further investigate why $\mathrm{H}^{+/-}$mice showed less oral selfadministration of MA, we assessed MA reward via CPP. When 
A

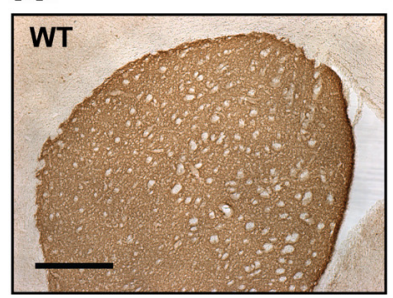

B
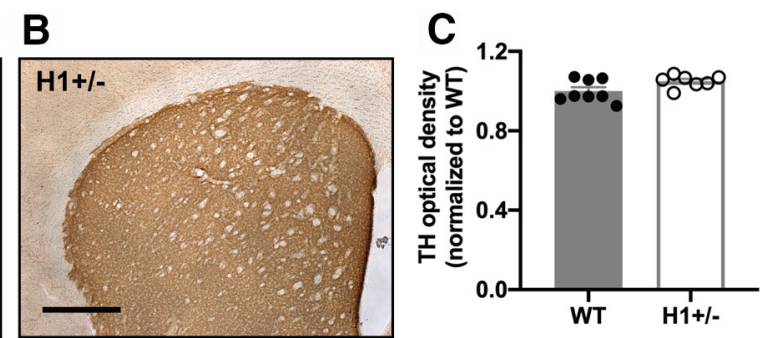

D

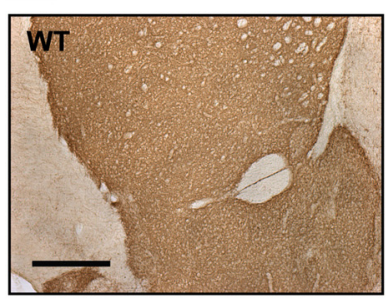

E

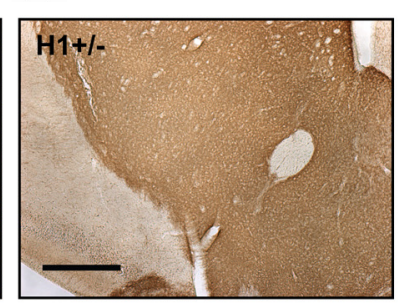

\section{$\mathbf{F}$}

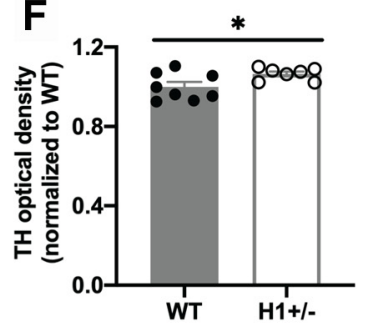

G

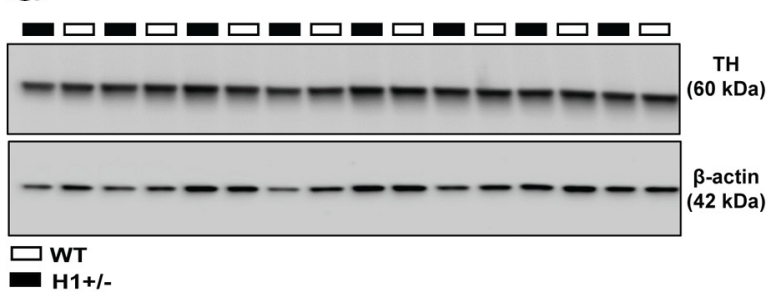

H

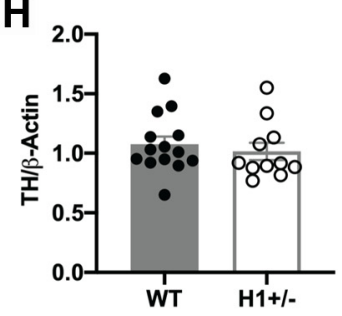

Figure 16. TH levels in striatum of $\mathrm{H} 1^{+/-}$mice. No difference in TH level was detected in the striatum between the $\mathrm{H} 1^{+/-}$ versus WT mice. $\boldsymbol{A}-\boldsymbol{F}$, Representative images showing immunohistochemical DAB staining on coronal sections of striatum (bregma: $1.18 \mathrm{~mm}$ to $0.86 \mathrm{~mm})$. $\boldsymbol{A}-\boldsymbol{C}$, Dorsal striatum. $\boldsymbol{D}-\boldsymbol{F}$, Ventral striatum, which includes NAc. Scale bars, $1 \mathrm{~mm}$. 0D analysis revealed a nonsignificant increase in TH OD in the dorsal striatum and a small but significant increase in TH intensity in the ventral striatum of $\mathrm{H} 1^{+/-}$compared with WT mice. ${ }^{*} p=0.04$ (unpaired $t$ test). WT: $n=8 ; \mathrm{H} 1^{+/-}: n=7 . \mathbf{G}, \boldsymbol{H}$, Immunoblot for TH protein level in the striatum. Representative immunoblot for TH shown in $\boldsymbol{G}$ with quantification shown in $\boldsymbol{H}$. There was no change in $\mathrm{TH}$ protein expression in the striatum of $\mathrm{H}^{+/-}$compared with WT mice. WT: $n=14 ; \mathrm{H} 1^{+/-}: n=11$.

mice were tested in an MA-free state (day 8), the genotypic difference in the time spent in the MA-paired side between day 8 and varied with MA doses (Fig. 6A; two-way ANOVA, $F_{(2,121) \text { interaction }}=$ $3.92 ; p=0.023 ; F_{(1,121) \text { Genotype }}=0.07, p=0.788 ; F_{(2,121) \text { Dose }}=$ $6.15, p=0.003)$. $1^{+1-}$ mice showed lower CPP to $0.5 \mathrm{mg} / \mathrm{kg}$ (WT: $n=23, \mathrm{H} 1^{+/-}: n=22$ ) MA but higher CPP to $2 \mathrm{mg} / \mathrm{kg}$ (WT: $n=19, \mathrm{H}^{+/-}: n=16$ ) MA compared with the WT mice (Fig. $6 A$; unpaired $t$ test; $0.5 \mathrm{mg} / \mathrm{kg}: t_{(45)}=-2.13, p=0.039$; $\left.2 \mathrm{mg} / \mathrm{kg}: t_{(45)}=2.18, p=0.036\right)$. Similar nonsignificant effects were observed during drug state-dependent CPP whereby $\mathrm{H} 1^{+/-}$mice exhibited lower and higher $\mathrm{CPP}$ at $0.5 \mathrm{mg} / \mathrm{kg}$ and $2 \mathrm{mg} / \mathrm{kg}$ MA doses, respectively (Fig. 6B; two-way ANOVA, $F_{(2,121) \text { interaction }}=1.86 ; p=0.160 ; F_{(1,121) \text { Genotype }}=0.23, p=$ $\left.0.634 ; F_{(2,121) \text { Dose }}=2.08, p=0.129\right)$. No sex differences or interactions were observed for any measure during MA-CPP testing (three-way ANOVA, day 8 to day $1: F_{(1,115) \text { Sex }}=0.77, p=0.381$, $F_{(2,115) \text { interaction }}=0.35, p=0.707$; day 9 to day $1: F_{(1,115) \operatorname{Sex}}=$ $\left.0.09, p=0.761, F_{(2,115) \text { interaction }}=1.26, p=0.287\right)$. The dosedependent difference in CPP indicates that $\mathrm{H} 1^{+/-}$showed a reduced sensitivity to the rewarding effect of low-dose MA and that a higher MA dose was required to elicit $\mathrm{CPP}$ in $\mathrm{H} 1^{+/-}$mice.

We also identified significant genotypic differences in MAinduced locomotor activity in the confined one-half of the CPP box during CPP training on days 3 and 5 (Fig. 7; mixed-effects ANOVA, day 3: $F_{(1,109) \text { Genotype }}=5.04, p=0.037, F_{(1,109) \operatorname{Sex}}=$ $0.06, p=0.800, F_{(22,1199) \text { Genotype } \times \text { Treatment } \times \text { Time }}=1.69, p=$ 0.024; day 5: $F_{(1,109) \text { Genotype }}=3.07, p=0.073, F_{(1,109) \mathrm{Sex}}=2.93$, $p=0.090, F_{(22,1199) \text { Genotype } \times \text { Treatment } \times \text { Time }}=$ 2.291, $p=0.0006$; days 2 and 4: $F_{(1,109) \text { Genotype } \times \text { Treatment } \times \text { Time }}<1, p>$ $0.5) . \mathrm{H} 1^{+1-}$ mice traveled less distance at $60 \mathrm{~min}$ after $2 \mathrm{mg} / \mathrm{kg}$ MA injection on day 3 and 5 (unpaired $t$ tests, day $3: t_{(31)}$ $=-2.26, p=0.031$; day $5: t_{(31)}=$ $-2.32, p=0.027)$. During statedependent CPP (following the two previous MA exposures) on day 9 when mice had twice as much open access space, we observed a decrease in MA-induced locomotor activity in $\mathrm{H}^{+/-}$mice (Fig. 8; mixed-effects ANOVA, day 9: $F_{(1,113) \text { Genotype }}$ $=3.05, p=0.083, F_{(1,113) \operatorname{Sex}}=0.16, p=0.695$, $F_{(2,113) \text { Genotype } \times \text { Treatment }}=3.78, p=0.026$; days 1 and 8: $F_{(2,115)}$ Genotype $\times$ Treatment $=$ $1.16,0.39$ for days 1 and 8 , respectively, $p$ values $>0.3$ ). This result was similar to the previously published results in the samesized open arena minus the CPP divider and floor textures in response to a single, acute MA dose of $2 \mathrm{mg} / \mathrm{kg}$ (Yazdani et al., 2015). Furthermore, we later demonstrate replication of reduced MA-induced locomotor activity in $\mathrm{H}^{+/-}$mice using the same $3 \mathrm{~d}$ protocol from the original publication (Yazdani et al., 2015) before tissue harvesting for mass spectrometry analysis (for later description of the results, see Fig. 20). There was no genotypic difference in the striatal level of either MA or its metabolite amphetamine at $30 \mathrm{~min}$ (i.p.) after injection of MA (Fig. 9; unpaired $t$ test, $t_{(14)}=-0.72,-0.22, p=0.480,0.826$ for MA and amphetamine, respectively; WT: $n=8$ and $\left.\mathrm{H}^{+/-}: n=8\right)$. Thus, differences in transport or metabolism of MA are unlikely to explain the decrease in MAinduced behavior in $\mathrm{H}^{+/-}$mice at $30 \mathrm{~min}$ after MA.

\section{MA-induced DA release in $\mathrm{H}^{+/-}$mice}

Because $\mathrm{H} 1^{+/-}$mice showed reduced MA self-administration and reward, we next examined basal extracellular DA and MAelicited DA release using in vivo microdialysis in the NAc, a brain region and neurochemical event that are necessary for MA reinforcement and reward (Prus et al., 2009; Keleta and Martinez, 2012; Bernheim et al., 2016). Linear regression analysis of no net flux in vivo microdialysis in the NAc indicated no significant change in either DA release/reuptake (extraction fraction or slope; Fig. 10A; two-way ANOVA, $F_{(1,31) \text { Genotype }}=2.86, p=0.10$; $\left.F_{(1,31) \text { Genotype } \times \text { Sex }}=2.52, p=0.12\right)$ or basal extracellular DA content or (Fig. 10B; two-way ANOVA, $F_{(1,31) \text { Genotype }}=0.06, p=$ $\left.0.81 ; F_{(1,31) \text { Genotype } \times \text { Sex }}=0.03, p=0.86\right)$. Following administration of $0.5 \mathrm{mg} / \mathrm{kg}$ MA (i.p.), WT mice exhibited an increase in extracellular DA, whereas $\mathrm{H} 1^{+/-}$mice showed a decrease in extracellular DA below baseline (Fig. 11A; mixed-effects ANOVA, $F_{(1,25) \text { Genotype }}=18.57, p<0.0001 ; F_{(11,275) \text { Time }}=1.63, p=0.09$; $F_{(11,275) \text { Genotype } \times \text { Time }}=4,71, p<0.0001$; unpaired $t$ tests for time $=-60$ to $0 \mathrm{~min}, t_{(25)}<0.60, p$ values $>0.60$; for time $=20$ to $180 \mathrm{~min}, t_{(25)}>2.25$, $p$ values $\left.<0.033\right)$. Administration of $2 \mathrm{mg} / \mathrm{kg}$ MA (i.p.) induced an increase in DA within the NAc of both genotypes, but $\mathrm{H}^{+/-}$mice again showed markedly lower MA-induced extracellular DA levels, in particular from 
100 to 180 min after MA (Fig. 11B; mixed-effects ANOVA, $F_{(1,31) \text { Genotype }}=$ 6.41, $p=0.02 ; F_{(11,341) \text { Time }}=8.29, p<$ $0.0001 ; F_{(11,341) \text { Genotype } \times \text { Time }}=5.58, p<$ 0.0001 ; unpaired $t$ tests, for time -60 to 0 and $40 \mathrm{~min}, t_{(31)}<1.5, p$ values $>0.15$; for time $20,60-180 \mathrm{~min}, t_{(31)}>2.0, p$ values $<0.05)$. Consistent with the genotypic differences in extracellular DA levels, for both the 0.5 and $2 \mathrm{mg} / \mathrm{kg} \mathrm{MA}$ doses, $\mathrm{H} 1^{+/-}$mice also showed a lower level of DOPAC (metabolite of DA) compared with WT mice (Fig. 11C,D; $0.5 \mathrm{mg} / \mathrm{kg}$ MA: mixed-effects ANOVA, $F_{(1,28) \text { Genotype }}=$ $1.50, p=0.23 ; F_{(11,308) \text { Time }}=13.33, p<$ $0.0001 ; F_{(11,308) \text { Genotype } \times \text { Time }}=2.76, p=$ 0.002; unpaired $t$ tests, for all times but $160 \mathrm{~min}, t_{(28)}<1.90$, $p$ values $>0.08$; for time $=160 \mathrm{~min}, t_{(28)}=2.37, p=$ $0.03 ; 2.0 \mathrm{mg} / \mathrm{kg} \mathrm{MA}:$ mixed-effects ANOVA, $F_{(1,25) \text { Genotype }}=24.09, p<$ $0.0001 ; F_{(11,275) \text { Time }}=29.04, p<0.0001$; $F_{(11,275) \text { Genotype } \times \text { Time }}=10.42, p<0.0001$; unpaired $t$ tests, for time -60 to 0 and 40 $\min , t_{(25)}<1.6$, $p$ values $>0.10$; for time $20,60-180 \mathrm{~min}, t_{(25)}>2.0, p$ values $<$ $0.05)$.

In examining glutamate levels, no net flux microdialysis study revealed no difference in basal extracellular level of glutamate (Fig. 12A; for slope, $t_{(14)}=0.77$, $p=0.45$; for $x$ intercept, $t_{(14)}=0.49$, $p=0.64$ ). Acute administration of 0.5 or $2 \mathrm{mg} / \mathrm{kg}$ MA did not induce much effect on extracellular glutamate levels, nor were there any genotypic differences in glutamate levels (Fig. 12 B, C; mixed-effects ANOVA, for $0.5 \mathrm{mg} / \mathrm{kg} \mathrm{MA,} F_{(1,28) \text { Genotype }}$ $=0.54, p=0.47 ; F_{(11,308) \text { Time }}=0.56$, $p=0.86 ; F_{(11,308) \text { Genotype } \times \text { Time }}=0.59$, $p=0.84$; for $2.0 \mathrm{mg} / \mathrm{kg} \mathrm{MA}, F_{(1,30) \text { Genotype }}=$ $1.46, p=0.24 ; F_{(11,330) \text { Time }}=1.89, p=$ 0.04; $F_{(11,330) \text { Genotype } \times \text { Time }}=0.59$, $p=0.84)$. To summarize, $\mathrm{H} 1^{+/-}$mice showed a significantly blunted MAinduced DA release in the NAc in the absence of any significant difference in baseline DA levels and in the absence of any significant differences in glutamate neurotransmission. No sex differences or interactions were observed. These results point toward an MA-induced deficit in DA release as a plausible functional mechanism underlying the deficit in the MA-induced behavioral responses in $\mathrm{H} 1^{+/-}$mice.

To further investigate the possible causes of the decreased capacity of MA to induce DA release in $\mathrm{H} 1^{+/-}$mice, we quantified basal striatal tissue levels of biogenic amines in drug-naive $\mathrm{H}^{+/-}$and WT mice. No genotypic difference was detected in the amount of DA and DOPAC (Fig. 13A; unpaired $t$ test, DA: $t_{(14)}=-0.30, p=0.766$; DOPAC: $t_{(14)}=-0.93, p=0.372 ; n=$ 8 per group), or in the levels of other biogenic amines, including HVA, 3-MT, 5-HT, etc. (Fig. 13A; unpaired $t$ test, HVA: $t_{(14)}=$ $0.08, p=0.938$; 3 -MT: $t_{(14)}=-0.53, p=0.372$; 5 -HT: $t_{(14)}=$ 1.02, $p=0.323$; 5-HIAA: $t_{(14)}=1.68, p=0.114$; noradrenaline: $n=8$.
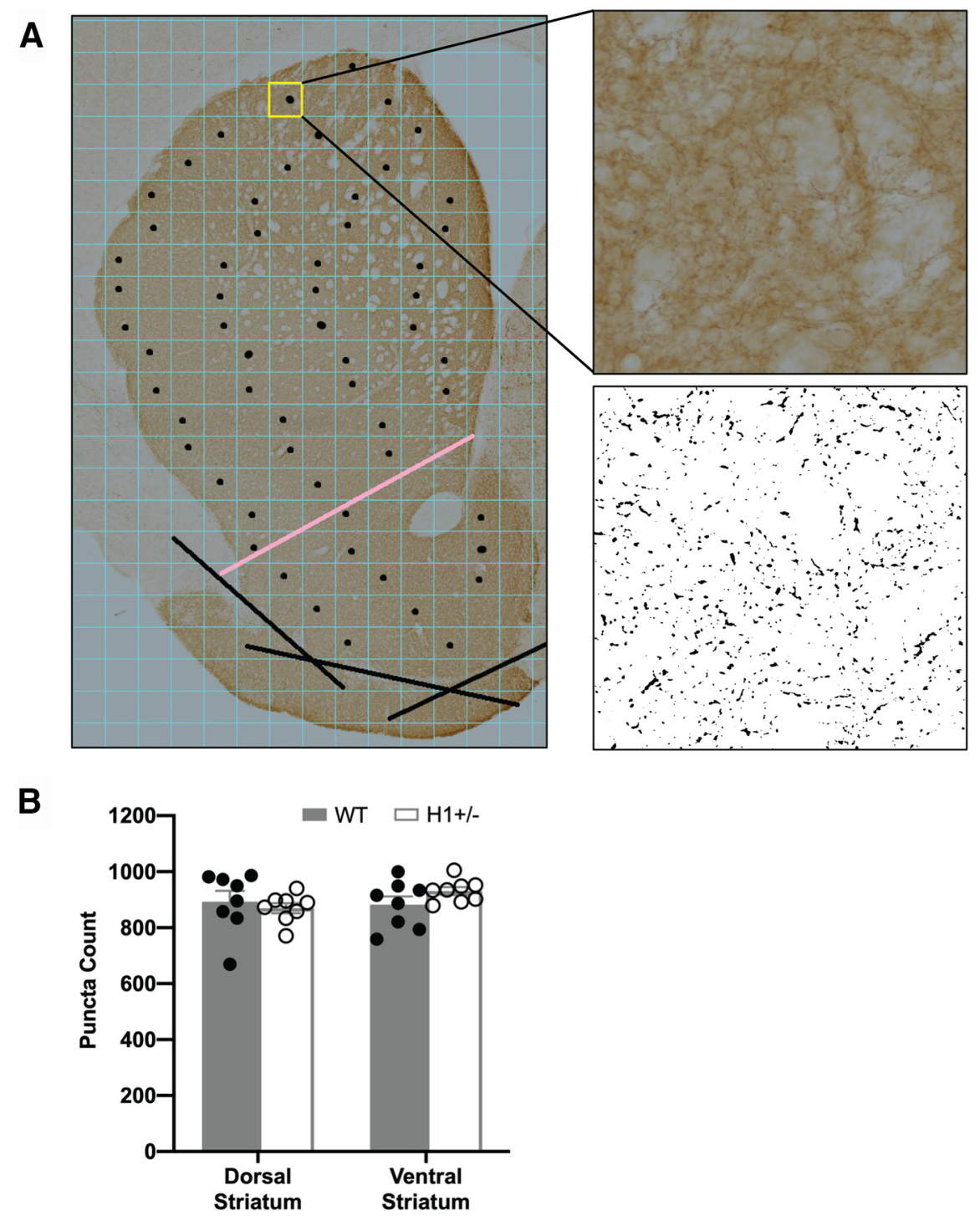

Figure 17. Schematics and puncta count of $\mathrm{TH} \mathrm{IHC}$ staining in $\mathrm{H} 1^{+/-}$mice. $A, A 225,000 \times 225,000 \mu \mathrm{m}$ grid was overlaid onto the images in ImageJ, and every third field (indicated by the black dots) was graded for total number of puncta. ROls were graded by subtracting the background, setting a threshold, creating a binary image, and conducting image on bottom right). $\boldsymbol{B}$, Stereological analysis of the number of TH-positive puncta revealed no genotypic difference on the number of dopaminergic terminals in the dorsal and ventral striatum of $\mathrm{H} 1^{+/-}$versus WT mice. WT: $n=8 ; \mathrm{H} 1^{+/-}$:

$\left.t_{(14)}=0.722, p=0.482\right)$. We also tested whether $\mathrm{H} 1^{+/-}$impacts the function of DAT by examining DAT-mediated DA uptake in synaptosomes prepared from whole striatal tissue. However, no difference in basal DAT function was detected (Fig. 13B; two-way ANOVA, $F_{(1,14) \text { interaction }}=0.01, p=0.911 ; F_{(1,14) \text { Genotype }}=0.02$, $p=0.903 ; F_{(1,14) \text { Treatment }}=0.26, p=0.619 ; n=4$ per group). In addition, there was no change in the protein level of DAT in the total striatal brain lysate in $\mathrm{H} 1^{+/-}$compared with WT mice (Fig. $13 C, D$; unpaired $t$ test, $t_{(23)}=0.32, p=0.750$; WT: $n=14$ and $\left.\mathrm{H} 1^{+/-}: n=11\right)$. An increase in DAT protein level was detected in the female mice (Fig. 13C,D; two-way ANOVA, $F_{(1,21) \mathrm{Sex}}=5.74$, $p=0.026, F_{(1,21) \text { Genotype }}=0.12, p=0.730 ; F_{(1,21) \text { interaction }}=0.07$, $p=0.800$; unpaired $t$ test, females vs males $t_{(23)}=2.53, p=0.019$; females: $n=13$; males: $n=12$ ). There was also no effect of MA on DAT protein level in the synaptosome of either $\mathrm{H}^{+/-}$or WT mice (Fig. 13 E, F; two-way ANOVA, $F_{(1,20) \text { Genotype }}=0.031, p=$ 
A

\begin{tabular}{|c|c|}
\hline Day & Assessments \\
\hline 1 & Prepulse inhibition, Novel object \\
\hline 2 & Marble burying, Light/dark, Porsolt Swim \\
\hline 3 & Accelerating rotarod (3 trials) \\
\hline 4 & Accelerating rotarod (3 trials) \\
\hline 5 & Accelerating rotarod (4 trials) \\
\hline
\end{tabular}

B

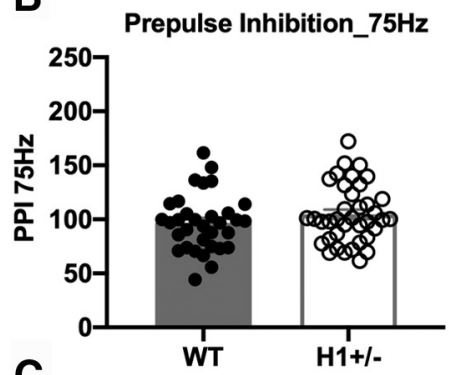

C
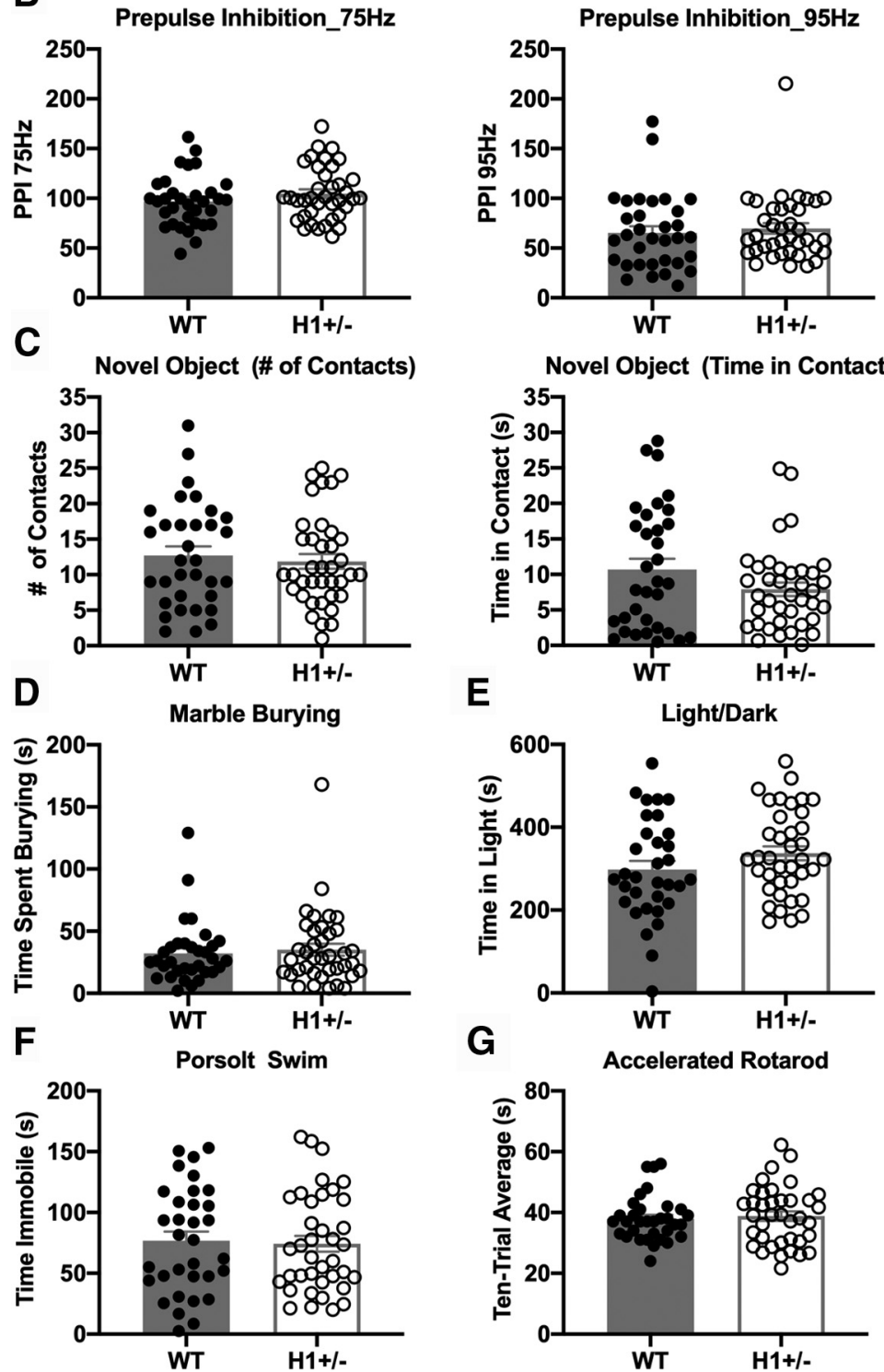
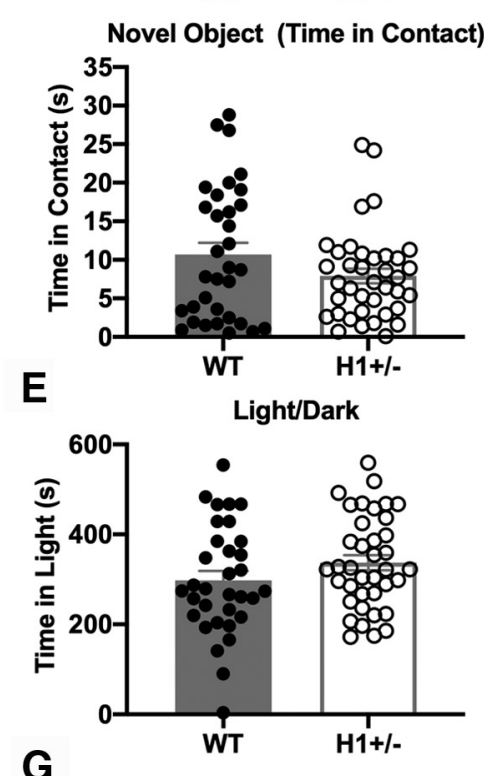

G

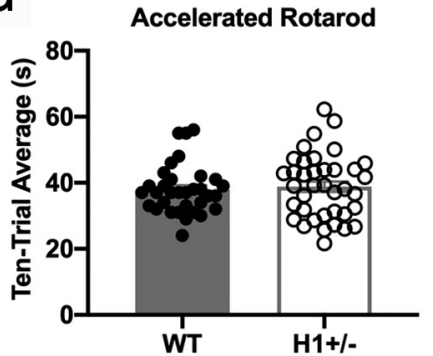

Figure 18. Behavioral test battery in $\mathrm{H}^{+/-}$mice. $A$, Timeline of behavioral battery testing in drug-naive $\mathrm{H} 1^{+/-}$and WT mice. $\boldsymbol{B}$, Prepulse inhibition of acoustic startle revealed no genotypic differences in the prepulse inhibition response to 75 or $95 \mathrm{~Hz}$. C, Novel object test revealed no genotypic differences in novel object contact number or contact time. D, Marble burying test revealed no genotypic differences in the amount of time (seconds) spent burying. $\boldsymbol{E}$, Light/dark shuttle box test revealed no genotypic differences in the amount of time (seconds) spent in the light zone. $\boldsymbol{F}$, Porsolt swim test revealed no genotypic differences in the amount of time immobile. $\mathbf{G}$, In the accelerating rotorod test, there were no genotypic differences in the 10 trial average time spent on the rotorod. WT: $n=33 ; \mathrm{H}^{+/-}: n=38$.

$0.86 ; F_{(1,20) \text { Treatment }}=0.037, p=0.85 ; F_{(1,20) \text { interaction }}=1.24, p=$ 0.28 ; WT SAL: $n=5$, WT MA: $n=6$, H1 ${ }^{+1-}$ SAL: $n=6$, and $\left.\mathrm{H} 1^{+/-} \mathrm{MA}: n=7\right)$.

TH expression in the mesolimbic and nigrostriatal brain regions of $\mathrm{H}^{+/-}$mice

In our previous transcriptome analysis of congenic mice that captured Hnrnph1 polymorphisms and decreased MA behavioral

sensitivity, we identified a decrease in expression of Nurr1 (Nr4a2), a transcription factor critical for dopaminergic neuron development (Yazdani et al., 2015). Thus, we hypothesized that dysfunctional mesolimbic and nigrostriatal DA pathways at the neuroanatomical level could underlie decreased MA-induced behaviors and DA release in $\mathrm{H}_{1}^{+/-}$mice. We tested this hypothesis by examining changes in the number of neurons and the number of projections from neurons in the dopaminergic mesolimbic and nigrostriatal pathways, which mediate reward and motor activity, respectively (Adinoff, 2004). Diagrams outlining the different brain regions assessed are presented in Figure 14. We first examined coexpression of hnRNP $\mathrm{H}$ (there are currently no commercially available antibodies for differentiating between hnRNP $\mathrm{H} 1$ and hnRNP H2) and $\mathrm{TH}$ (the rate-limiting enzyme for the synthesis of DA) (Daubner et al., 2011). Results showed that hnRNP H and TH were coexpressed in the same midbrain $\mathrm{TH}$ neurons of the VTA and substantia nigra pars compacta $(\mathrm{SNc})$ at a similar level in both genotypes (Fig. 15A). hnRNP H immunostaining was primarily nuclear, whereas $\mathrm{TH}$ immunostaining was cytoplasmic. We next examined expression of $\mathrm{TH}$ in the dopaminergic neurons of the mesolimbic and nigrostriatal circuit (Figs. 15, 16). TH DAB immunohistostaining in the VTA and SNc of the midbrain (Fig. $15 B$ ) indicated no significant genotypic differences in $\mathrm{TH}$ optical density (OD) (Fig. 15C; unpaired $t$ test, VTA: $t_{(13)}=$ $-1.29, p=0.220$; SNc: $t_{(13)}=-0.75, p=$ 0.466; WT: $n=7$ and $\left.\mathrm{H} 1^{+/-}: n=8\right)$. There was also no genotypic difference in the number (Fig. 15D; unpaired $t$ test, $t_{(14)}=0.02, t=0.985 ; n=8$ per genotype) or diameter (Fig. $15 E ; t_{(14)}=0.88, p=$ $0.395 ; n=8$ per genotype) of TH-positive neuron of the VTA and SNc. Immunoblot analysis indicated no significant difference in TH protein level in the midbrain (Fig. $15 F, G$; unpaired $t$ test, $t_{(18)}=0.67$, $p=0.510 ; n=10$ per genotype).

TH DAB immunostaining in the striatum indicated no change in TH OD in the dorsal striatum between $\mathrm{H}^{+/-}$and WT mice (Fig. 16A-C; unpaired $t$ test, $t_{(13)}=$ 2.07, $p=0.10$; WT: $\left.n=8 ; \mathrm{H}^{+/-}: n=7\right)$. However, a small, but statistically significant increase in TH OD was observed in the ventral striatum (which includes the NAc) of the $\mathrm{H} 1^{+/-}$mice (Fig. 16D-F; unpaired $t$ test, $t_{(13)}=2.30, p=0.040$; WT: $n=8$ and $\mathrm{H}^{+/-}: n=$ 7). To measure TH-positive puncta as an indirect estimate of the number of DA terminals in the striatum, we performed stereology under higher magnification (Fig. 17A) and detected no difference in the number of TH-positive puncta between the $\mathrm{H} 1^{+/-}$ 
and WT mice in the dorsal striatum or in the ventral striatum (Fig. $17 B$; dorsal: $t_{(14)}$ $=0.55, p=0.588$; ventral: $t_{(14)}=-1.49$, $p=0.159, n=8$ per genotype). Immunoblot analysis indicated no significant difference in $\mathrm{TH}$ protein level in the whole striatum (Fig. 16G,H; unpaired $t$ test, $t_{(23)}$ $=0.62, p=0.540 ; \mathrm{WT}: n=14$ and $\left.\mathrm{H} 1^{+/-}: n=11\right)$. Together, analysis of the dopaminergic mesolimbic and nigrostriatal DA circuit did not provide strong evidence for changes in the expression of $\mathrm{TH}$ within cell bodies or terminals or changes in the number of $\mathrm{TH}$-positive terminals that could explain behavioral differences in $\mathrm{H} 1^{+/-}$mice.

An important message gleaned from the above results is that the behavioral and neurochemical deficits exhibited by $\mathrm{H} 1^{+/-}$mice appear to manifest only under the influence of MA. In further support of this notion, a screen of WT ( $n=$ $33)$ and $\mathrm{H}^{+/-}(n=38)$ mice in a behavioral test battery (Fig. 18A) did not detect any genotypic differences in sensorimotor gating (Fig. $18 B, C$; prepulse inhibition of acoustic startle: unpaired $t$ test, $75 \mathrm{~Hz}$ : $t_{(69)}=-1.26, p=0.213,95 \mathrm{~Hz}: t_{(69)}=$ $-0.53, p=0.598$; novel object: unpaired $t$ test, contact number: $t_{(69)}=0.51, t=$ 0.615 , contact time: $t_{(69)}=1.62, p=$ 0.111 ), anxiety-like behaviors (Fig. $18 D, E$; marble burying, unpaired $t$ test, $t_{(69)}=-0.44, p=0.660$; light/dark shuttle box: unpaired $t$ test, $\left.t_{(69)}=-1.48, p=0.145\right)$, depressive-like behaviors (Fig. 18F; $t_{(69)}=0.24, p=0.810$ ), or in sensorimotor coordination (Fig. 18G; unpaired $t$ test, $t_{(69)}=-0.44, p=0.663$ ). The null results from this behavioral battery, combined with the lack of genotypic differences in saline-induced locomotion/response to a novel environment, and in various indices of basal DA transmission in the striatum argue for an active, MA-induced cell biological mechanism linking Hnrnph1 dysfunction to MA behavior.

\section{Methamphetamine-induced changes in total and synaptic level of hnRNP H}

The above neuroanatomical studies failed to support a neuroanatomical hypothesis of reduced neurodevelopment of DA projection pathways that could underlie reduced MA-induced DA release and behavior in $\mathrm{H}_{1}^{+/-}$mice. Thus, to further explore the possibility of a synaptic, MA-induced cell biological mechanism that could underlie $\mathrm{H}^{+/-}$behavior, we next examined changes in the synaptic localization of hnRNP $\mathrm{H}$, which is potentially relevant for understanding how $\mathrm{H}^{+/-}$could alter MA-induced DA release. Surprisingly, we identified a twofold increase in hnRNP $\mathrm{H}$ protein level in the striatal synaptosome of $\mathrm{H}^{+/-}$mice, regardless of treatment (Fig. 19A,B; two-way ANOVA, $F_{(1,27) \text { Genotype }}=24.36, p=3.63 \mathrm{E}-5 ; F_{(1,27) \text { Treatment }}=$ $0.23, p=0.636 ; F_{(1,27) \text { interaction }}=0.41, p=0.528 ; \mathrm{WT}[n=15] \mathrm{vs}$ $\mathrm{H} 1^{+l-}[n=16]:$ unpaired $t$ test, $\left.t_{(29)}=-5.51, p=2.176 \mathrm{E}-5\right)$. In contrast, there was no significant genotypic difference in hnRNP $\mathrm{H}$ protein level in bulk striatal tissue in response to saline or MA (Fig. 19C,D; two-way ANOVA, $F_{(1,20) \text { Genotype }}=0.60, p=0.450$; $F_{(1,20) \text { Treatment }}=0.01, p=0.952 ; F_{(1,27) \text { interaction }}=0.37, p=0.548$; $n=6$ per group), indicating a change in localization rather than total hnRNP $\mathrm{H}$ protein in $\mathrm{H} 1^{+/-}$mice.

To identify changes in the levels of other synaptic proteins that could mechanistically link the robust increase in synaptic hnRNP H with decreased MA-induced DA release and behavior, we examined genotypic differences in the synaptosomal proteome in the striatum of $\mathrm{H}^{+/-}$and WT mice treated with MA versus saline using LC-MS/MS. At the behavioral level, $\mathrm{H} 1^{+/-}$showed reduced MA-induced locomotor activity only in response to MA on day 3 (Fig. 20C; mixed-effects ANOVA, $F_{(1,12) \text { Genotype }}=8.54, p=0.013 ; F_{(1,12) \text { Treatment }}=77.42, p=$ $1.4 \mathrm{E}-6 ; F_{(1,12) \text { Genotype } \times \text { Treatment }}=5.85, p=0.032 ; F_{(5,60) \text { Time }}=$ $1.83, p=0.120 ; F_{(5,60) \text { Genotype } \times \text { Treatment } \times \text { Time }}=1.23, p=0.305$; unpaired $t$ test for WT vs $\mathrm{H} 1^{+/-}$after MA at each $5 \mathrm{~min}$ bin, $t_{(6)}=-1.63,-1.67,-2.44,-2.46,-2.41,-3.01, p=0.154$, $0.147,0.050,0.049,0.052,0.023$ for $5,10,15,20,25$, and 30 min time point, respectively). In contrast, no difference in locomotor activity was detected between WT and $\mathrm{H} 1^{+/-}$in response to saline (Fig. 20A,B; mixed-effects ANOVA, day 1: $F_{(1,12) \text { Genotype }}=2.40, p=0.147 ; F_{(1,12) \text { Treatment }}=0.203, p=$ $0.660 ; F_{(1,12) \text { Genotype } \times \text { Treatment }}=0.17, p=0.684 ; F_{(11,132) \text { Time }}=$ $1.89, p=0.046 ; F_{(11,132) \text { Genotype } \times \text { Treatment } \times \text { Time }}=1.19, p=0.301$; day 2: $F_{(1,12) \text { Genotype }}=1.27, p=0.283 ; F_{(1,12) \text { Treatment }}=0.466, p=$ $0.508 ; F_{(1,12) \text { Genotype } \times \text { Treatment }}=0.21, p=0.656 ; F_{(11,132) \text { Time }}=$ $0.45, \quad p=0.930 ; \quad F_{(11,132) \text { Genotype } \times \text { Treatment } \times \text { Time }}=1.32$, $p=0.219)$. Overall, proteomic analysis for the main effect of Genotype identified a highly enriched upregulation of mitochondrial proteins in the $\mathrm{H}^{+/-}$striatal synaptosome regardless of treatment (Fig. 21A). Enrichment analysis for the set of top differentially expressed proteins (absolute $\log _{2} \mathrm{FC}>0.2 ; p<0.05$ ) between $\mathrm{H}^{+/-}$and WT mice revealed a highly significant enrichment for mitochondrial respiratory chain complex I assem- 
A

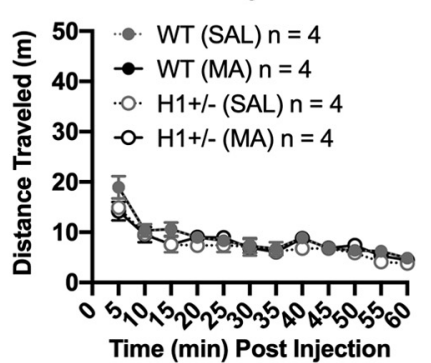

B

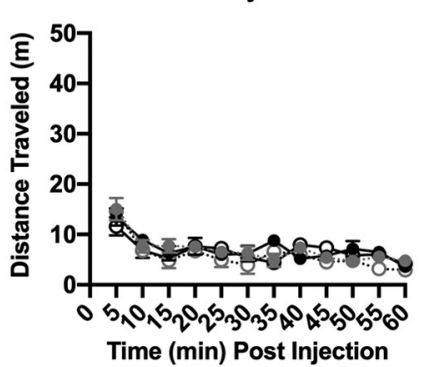

C

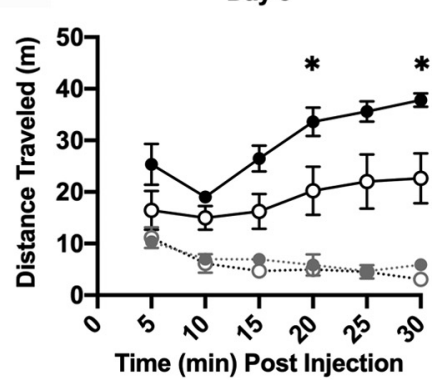

Figure 20. MA-induced locomotor activity in $\mathrm{H}^{+/-}$and WT mice that were used for harvest of striatal synaptosome for proteomic analysis. On days 1 and 2, mice were injected (i.p.) with saline (SAL) and placed into apparatus for $1 \mathrm{~h}$. On day 3, mice were injected (i.p.) with $2 \mathrm{mg} / \mathrm{kg} \mathrm{MA}$ and placed into apparatus for 30 min followed by immediate death and removal of the striatum. $\boldsymbol{A}, \boldsymbol{B}$, Locomotor activity on day $1(\boldsymbol{A})$ and day $2(\boldsymbol{B})$ for $1 \mathrm{~h}$ in $5 \mathrm{~min}$ bin. No genotypic difference in total distance traveled was observed in response to a SAL injection (i.p.) on day 1 or day 2. C, Locomotor activity on day 3 for $30 \mathrm{~min}$ in six, 5 min bins. In response to MA (2 mg/kg, i.p.), H1 ${ }^{+/-}$showed less distance traveled compared with WT. ${ }^{*} p<0.05$ (unpaired $t$ test for each 5 min bin for WT vs $\mathrm{H} 1^{+/-}$: for time 20 and $\left.30 \mathrm{~min}\right)$.

A

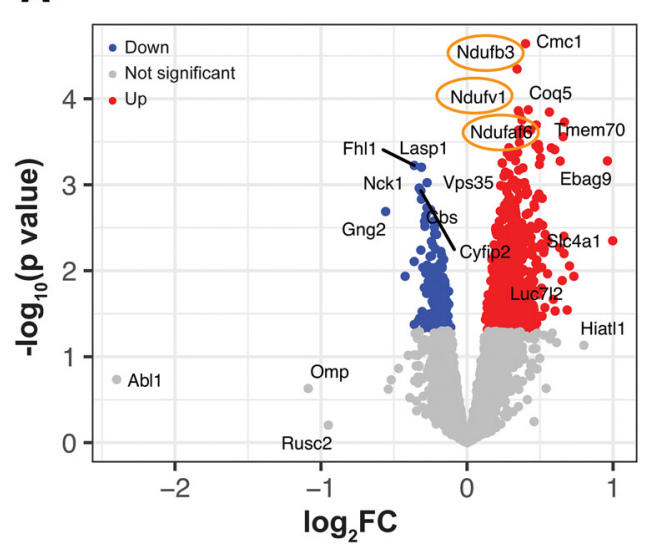

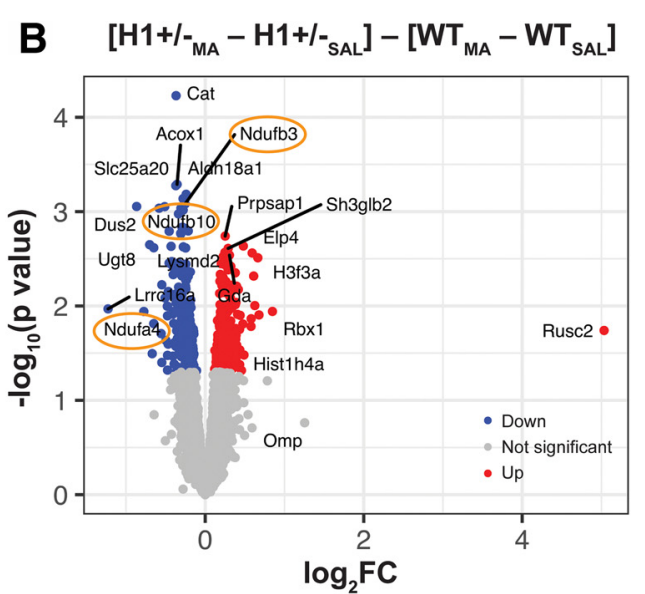

Figure 21. Proteomic analysis of the striatal synaptosome in $\mathrm{H}^{+/-}$mice. On days 1 and 2, mice were injected (i.p.) with saline (SAL) and placed into apparatus for 1 h. On day 3, mice were injected (i.p.) with $2 \mathrm{mg} / \mathrm{kg}$ MA and placed into the apparatus for $30 \mathrm{~min}$, and then whole striatum was rapidly harvested via free form dissection. Locomotor activity for all $3 \mathrm{~d}$ is shown in Figure 20 . The LIMMA package was used for differential analysis with Genotype and Treatment as factors. A ranked list was generated from the analysis, and the fgsea R package was used to perform preranked analysis, with proteins filtered for absolute $\log _{2} \mathrm{FC}>0.2$ and $p<0.05$. A, Proteomic analysis was performed to identify differences in protein abundance in the striatal synaptosome of $\mathrm{H} 1^{+/-}$ versus WT mice. The volcano plot shows the top differentially expressed proteins in the $\mathrm{H}^{+/-}$versus WT striatal synaptosome. Proteins that are part of the mitochondrial respiratory complex I are circled in orange. $\boldsymbol{B}$, Proteomic analysis was performed to examine Genotype $\times$ Treatment interactions in protein abundance in the striatal synaptosome of $\mathrm{H} 1^{+/-}$versus WT mice. This analysis accounted for baseline differences by examining the difference of the difference between the $\mathrm{H}^{+/-}$and WT in response to MA: $\left(\mathrm{H}^{+/-}{ }_{\mathrm{MA}}^{-H} 1^{+/-}{ }_{\text {SAL }}\right)-\left(\mathrm{WT}_{\mathrm{MA}}-\mathrm{WT}_{\mathrm{SAL}}\right)$. The volcano plot shows the top differential expressed proteins between the $\mathrm{H}^{+/-}$versus WT striatal synaptosome in response MA. Proteins that are part of the mitochondrial respiratory complex I are circled in orange. Network and pathway analysis in Figure 21-1 (available at https://doi.org/10.1523/JNEUROSCl.1808-19.2019.f21-1) also detected an enrichment of proteins involved in metabolic processes in the $\mathrm{H} 1^{+/-}$and WT striatal synaptosome in response to MA (normalized to baseline).

bly (Table 1). In examining MA-induced changes in synaptic proteins in $\mathrm{H}^{+/-}$versus WT mice, we again identified an enrichment for alterations in metabolic processes involving components of mitochondrial complex I and V (Fig. 21B; Fig. 21-1, available at https://doi.org/10.1523/JNEUROSCI.1808-19.2019. f21-1; Table 2). Interestingly, in response to MA, there was a decrease in the level of mitochondrial proteins in the $\mathrm{H} 1^{+/-}$ mice, but an increase in the WT mice (Fig. 22). The findings were independently validated with a separate cohort of mice, which also pointed to a trending, nonsignificant pattern of an increase in expression of all three mitochondrial proteins in saline-treated $\mathrm{H} 1^{+/-}$mice and a trending, nonsignificant decrease in all three mitochondrial proteins in response to MA (Fig. 23; unpaired $t$ test, NDUFS2: $t_{(6)}=-1.39 p=0.107$; ATP5A1: $t_{(6)}=-1.64, p=$ 0.077; ATP5F1: $t_{(6)}=-1.24, p=0.131 ; n=4$ per group).

\section{Discussion}

Here, we extend a role for Hnrnph1 in MA reinforcement and reward (Fig. 24). A heterozygous frameshift $16 \mathrm{bp}$ deletion of the first coding exon of Hnrnph1 reduced MA oral operant selfadministration and MA-induced CPP (Figs. 3, 6) and induced a robust reduction in MA-induced DA release in the NAc (Fig. 11). This DA anomaly occurred without any differences in (1) basal extracellular DA (Fig. 10A,B); (2) basal DA content within striatal tissue (Fig. 13A); (3) DA uptake (Fig. 13B); (4) the number or staining of midbrain DA neurons within the mesolimbic and nigrostriatal dopaminergic circuits (Fig. 15); or (5) any robust changes in the number of forebrain striatal puncta originating from these neurons (Fig. 16). The combined results suggested an alternate mechanism underlying the decreases in MA-induced DA release and behavior in $\mathrm{H}^{+/-}$mice. In further support of an MA-induced cell biological mechanism, there was no effect of $\mathrm{H} 1^{+/-}$on spontaneous locomotion, anxiety- and depressive-like behaviors, or sensorimotor function (Fig. 18).

$\mathrm{H} 1^{+/-}$mice showed less MA-CPP at $0.5 \mathrm{mg} / \mathrm{kg}$ but greater $\mathrm{CPP}$ at $2 \mathrm{mg} / \mathrm{kg}$ than WT mice (Fig. 6). One interpretation is that MA-CPP exhibits an inverted U-shaped dose-response curve 
Table 1. Differentially expressed proteins in $\mathrm{H1}^{+/-}$versus $\mathrm{WT}^{a}$

\begin{tabular}{llll}
\hline G0 term & $p$ & FDR & Proteins \\
\hline Mitochondrial respiratory chain complex I assembly & $2.1 \mathrm{E}-12$ & $1.4 \mathrm{E}-09$ & SAMM50, NDUFB10, NDUFAF6, NDUFB3, NDUFA1, NDUFAF2, NDUFV3, NDUFV1 \\
Complex I biogenesis & $1.7 \mathrm{E}-11$ & $1.6 \mathrm{E}-09$ & NDUFB10, NDUFAF6, NDUFB3, NDUFA1, NDUFAF2, NDUFV3, NDUFV1 \\
Respiratory electron transport & $2.3 \mathrm{E}-11$ & $1.6 \mathrm{E}-09$ & NDUFB10, NDUFAF6, NDUFB3, NDUFA1, NDUFAF2, NDUFV3, NDUFV1, COX5A \\
\hline
\end{tabular}

${ }^{a}$ The top three gene ontology (G0) terms for the top differential expressed protein (shown in Fig. $21 A$ ) in the $\mathrm{H} 1^{+/-}$versus WT striatal synaptosome.

Table 2. Differentially expressed proteins in $\left[\mathrm{H1}^{+/-}{ }_{(\mathrm{MA})}-\mathrm{H1}^{+/-}{ }_{(\mathrm{SAL})}\right]-\left[\mathrm{WT}_{(\mathrm{MA})}-\mathrm{WT}_{(\mathrm{SAL})}\right]^{a}$

\begin{tabular}{|c|c|c|c|}
\hline G0 term & $p$ & FDR & Proteins \\
\hline Metabolic pathways & $4.2 \mathrm{E}-10$ & 1.7E-08 & NDUFB10, NDUFB3, ATP5A1, MB0AT2, HSD17B4, ATP5F1, ATP50, AGPAT1, UGT8, GANAB, MTHFD1L, ACOX1, AGPS, NDUFS1, ALDH18A1 \\
\hline Parkinson's disease & 3.6E-09 & 7.0E-08 & NDUFB10, NDUFB3, ATP5A1, NDUFS1, VDAC1, ATP5F1, ATP50 \\
\hline $\begin{array}{l}\text { Mitochondrial ATP synthesis } \\
\text { coupled proton transport }\end{array}$ & 4.1E-06 & $1.2 \mathrm{E}-3$ & ATP5A1, SLC25A20, ATP5F1, ATP50 \\
\hline
\end{tabular}

The top 3 gene ontology (G0) terms for the top differential expressed proteins (shown in Fig. 21B) in the $\mathrm{H} 1^{+/-}$versus WT striatal synaptosome in response to MA.
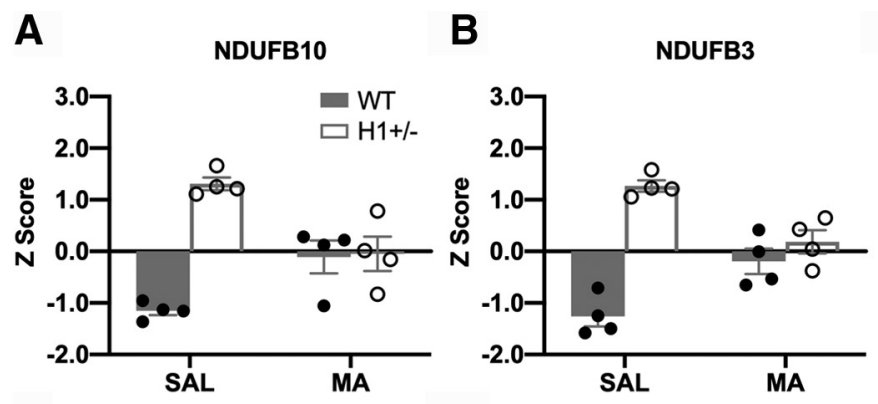

D ATP5A1

$E$
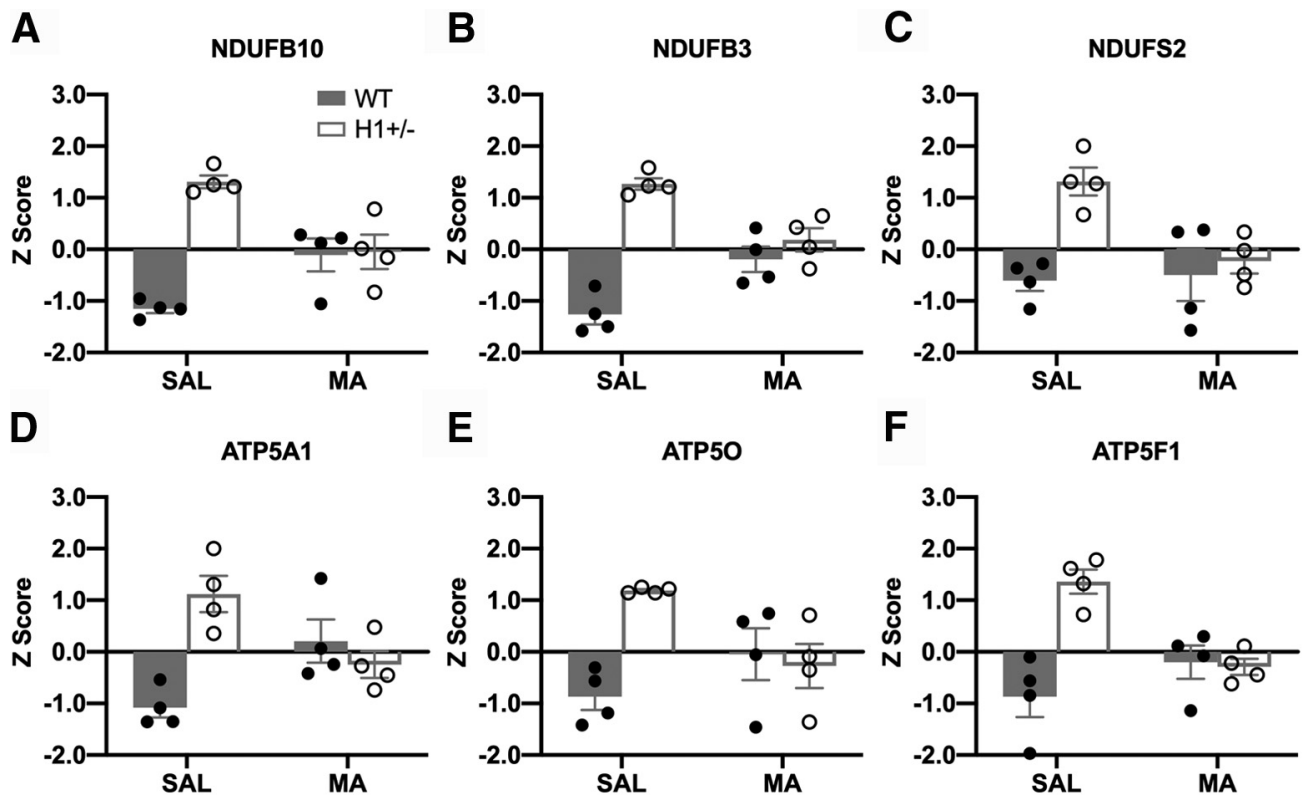

$\mathbf{F}$

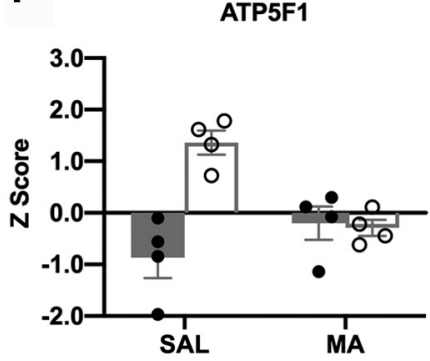

Figure 22. Protein expression profiles of select mitochondrial proteins in the striatal synaptosome of $\mathrm{H}^{+/-}$and WT mice from the proteomic dataset. The protein abundance for the mitochondrial proteins is shown for the four groups: $\mathrm{WT}(\mathrm{SAL}), \mathrm{H} 1^{+/-}(\mathrm{SAL}), \mathrm{WT}(\mathrm{MA})$, and H1 ${ }^{+/-}(\mathrm{MA})$. Opposing Genotype $\times$ Treatment effects on protein levels are shown for the mitochondrial complex I components $(\boldsymbol{A}-\boldsymbol{C})$ and complex V ATPase subunits $(\boldsymbol{D}-\boldsymbol{F})$. MA administration induced a decrease in protein expression of these subunits in $\mathrm{H} 1^{+/-}$mice and an increase in WT mice.

(Uhl et al., 2014) in WT and that $\mathrm{H} 1^{+/-}$shifts this curve to the right, yielding reduced sensitivity to positive and negative motivational valence of MA at lower versus higher doses. Consistent with this interpretation, $\mathrm{H}^{+/-}$mice exhibited blunted operant oral MA reinforcement. The combined data are consistent with $\mathrm{H} 1^{+/-}$mice self-administering less MA because they are less sensitive to the physiological and interoceptive effects of MA due to a reduced MA-induced DA release.

$\mathrm{H} 1^{+/-}$mice exhibited a blunted DA response to 0.5 and 2 $\mathrm{mg} / \mathrm{kg}$ MA (Fig. 11A,B). This effect on MA-induced DA release could not be explained by alterations in total DA levels (Fig. 13A) or in DAT levels or function at the presynaptic membrane (Fig. $13 B-F)$. An alternative explanation to DAT dysfunction is that the Hnrnph1 mutation somehow decreases MA binding to DAT, limiting its entry into presynaptic dopaminergic neuronal terminals and decreasing DA release. Future studies are necessary to examine MA binding to DAT in $\mathrm{H} 1^{+/-}$mice.

Our findings support a dopaminergic mechanism underlying reduced MA reward and reinforcement in $\mathrm{H}^{+/-}$mice. Nevertheless, we acknowledge the potential involvement of additional neurotransmitter systems and brain regions. We did not identify any difference in basal or MA-induced changes in extracellular glutamate levels in the NAc of $\mathrm{H} 1^{+/-}$mice. While MA reward is generally attributed to an increase in DA release in the NAc (Segal and Kuczenski, 1997; Adinoff, 2004), MA also increases release of norepinephrine and serotonin by targeting their respective transporters that could modulate the locomotor stimulant and/or rewarding response to psychostimulants, such as MA (Haughey et al., 2000; Rothman et al., 2001; Zaniewska et al., 2015). Future studies are warranted to address these other neurotransmitters in MA-induced behavioral dysfunction in $\mathrm{H}^{+/-}$mice as well as the possibility that $\mathrm{H}^{+/-}$has a pleiotropic influence on behavioral (e.g., cognitive, antidepressant) and neurochemical responses to drugs targeting other membrane transporters, such as NET and SERT. For example, phosphorylation of the RBP hnRNP K increases expression of SERT protein via changes in binding to the distal polyadenylation element of the transporter (Yoon et al., 2013).

The twofold increase in hnRNP H protein in the striatal synaptosome of $\mathrm{H}^{+/-}$mice with no change in total hnRNP H protein was surprising. This finding was observed in multiple replication studies and suggests a redistribution of hnRNP $\mathrm{H}$ protein to the synapse in $\mathrm{H}^{+/-}$mice. We performed LC-MS/MS analyses on striatal synaptosomes following $2 \mathrm{mg} / \mathrm{kg} \mathrm{MA}$ (i.p.) to 
A
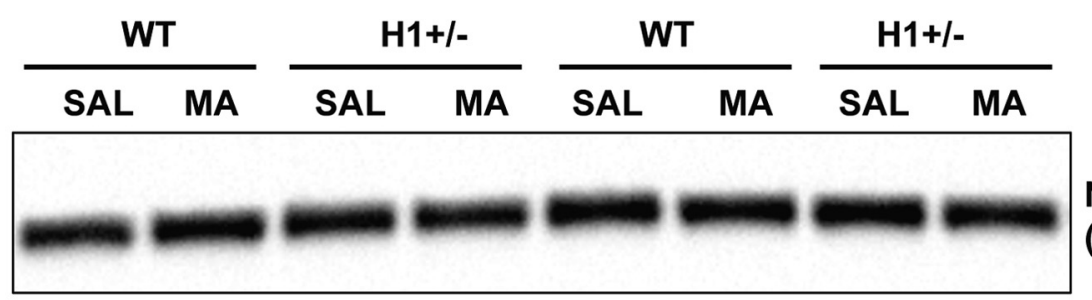

NDUFS2

(53 kDa)

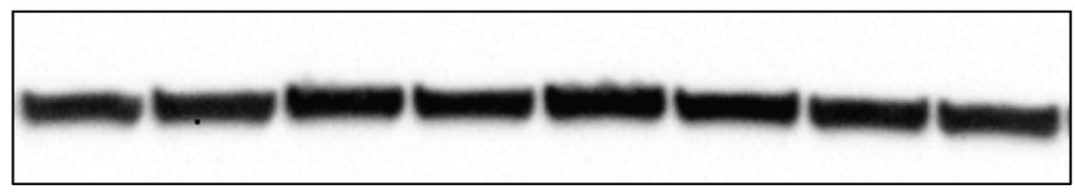

\section{ATP5A1 \\ (55 kDa)}

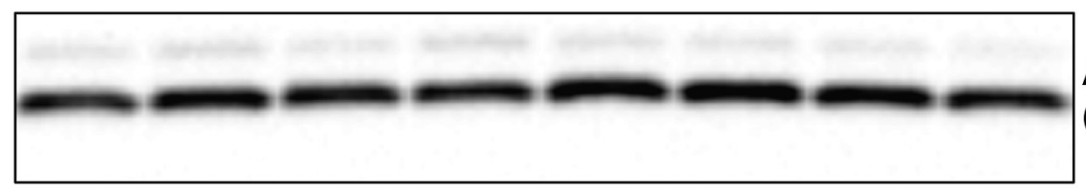

ATP5F1

(25 kDa)

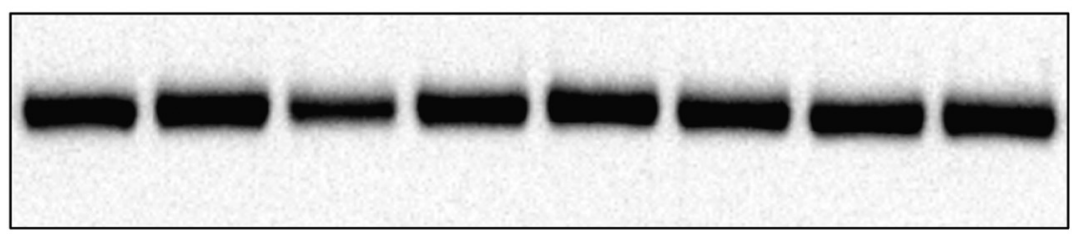

PSD95

(95 kDa)

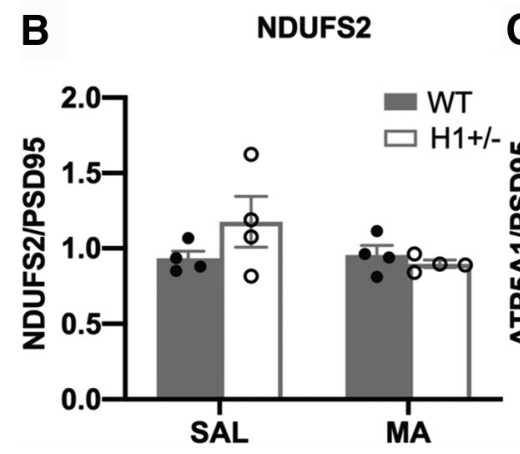

C

ATP5A1

D

ATP5F1
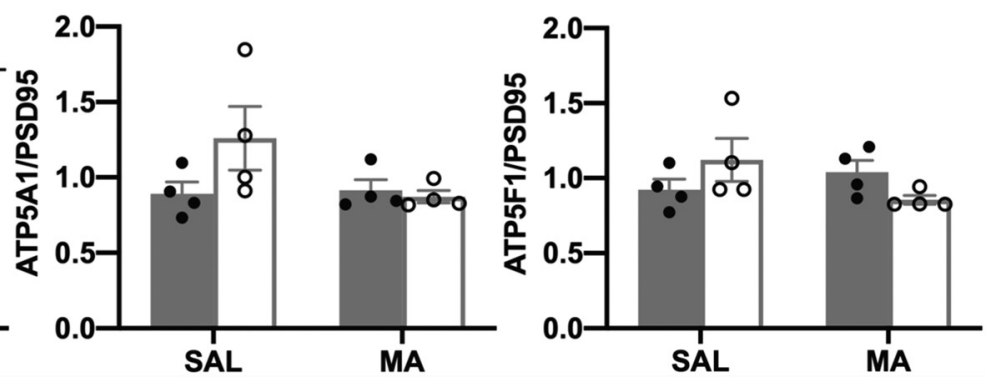

Figure 23. Immunoblots of select mitochondrial proteins in the synaptosome of $\mathrm{H}^{+/-}$and WT mice. Three mitochondrial proteins (NDUFS2, ATP5A, and ATP5F1) were selected for independent validation of mass spectrometry results in a separate sample cohort via immunoblot. A, Immunoblots for NDUFS2, ATP5A1, and ATP5F1. B-D, Quantification of protein expression of three select mitochondrial proteins. All three proteins show the same trend as the mass spectrometry results depicted in Figure 9 where an increase in expression was detected in SAL-treated $\mathrm{H} 1{ }^{+/-}$versus SAL-treated WT mice. $n=4$ per genotype per dose.

further understand the effect of increased synaptosomal hnRNP $\mathrm{H}$ on global changes in protein expression and the underlying cell biological mechanisms. We identified a higher abundance of several mitochondrial proteins, in particular, complex I of the mitochondrial respiratory chain in $\mathrm{H} 1^{+/-}$mice. The mammalian complex I consists of 38 nuclear DNA-encoded subunits (Sharma et al., 2009), and our proteomic analysis identified 8 of the 38 subunits that showed higher expression in $\mathrm{H} 1^{+/-}$mice (Figs. 21-23). Proteomics has been widely used to study the effects of MA on protein expression in the brain tissues of animals (Liao et al., 2005; Faure et al., 2009; Bosch et al., 2015). Iwazaki et al. (2006) used two-dimensional gel electrophoresis proteomics and found that a single low dose of MA (1 mg/kg) administration in rats induced differential expression of proteins involved in mitochondria/oxidative metabolism. Furthermore, chronic exposure of $1 \mathrm{mg} / \mathrm{kg}$ MA induced locomotor sensitization and neurotoxicity along with a downregulation of numerous striatal proteins indicating mitochondrial dysfunction and an oxidative response (Iwazaki et al., 2007; Chin et al., 2008).

Recent studies showed that postsynaptic dendritic mitochondrial fission and fusion processes mediate cellular and behavioral plasticity, spine and synapse formation, and synaptic function ( $\mathrm{Li}$ et al., 2004; Oettinghaus et al., 2016; Chandra et al., 2017; Divakaruni et al., 2018). Dynamin-related protein (Drp1), a GTPase involved in mitochondria fission, has been shown to regulate addiction-relevant behavior during early cocaine abstinence (Chandra et al., 2017), with inhibition of mitochondrial fission blunting cocaine-seeking and locomotor sensitization. While the results of our synaptosomal proteome dataset did not reveal any mitochondrial fission and fusion mediators, it is still possible that changes in mitochondrial proteins in the postsynaptic dendrites contribute to behavioral differences. Future studies will isolate potential presynaptic versus postsynaptic mechanisms.

Most mitochondrial proteins are nuclear-encoded and must be transported to mitochondria for organelle-coupled translation (Williams et al., 2014). RBPs play a critical role in targeting mRNAs to membrane-bound organelles, such as mitochondria. RBPs interact with mRNAs and chaperone them toward mitochondrial outer membranes where they are translated (Gerber et al., 2004; García-Rodríguez et al., 2007; Eliyahu et al., 2010; Gehrke et al., 2015). RBPs recognize and bind mitochondria- 


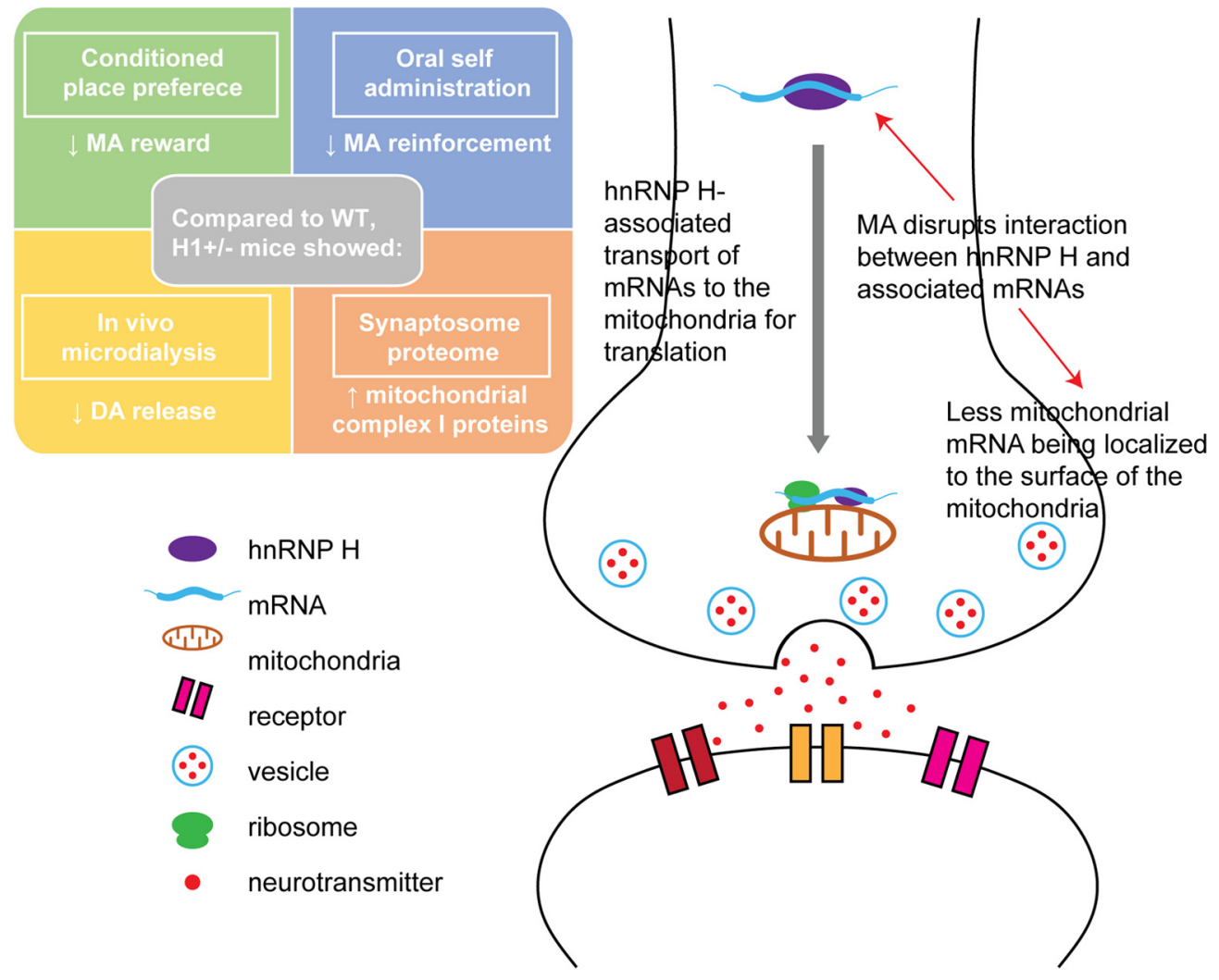

Figure 24. Proposed model linking increased synaptic mitochondria with a decrease in MA-induced DA release and motivated behaviors. Compared with WT mice, $\mathrm{H1}{ }^{+/-}$mice showed reduced MA-induced DA release in the NAc and reduced sensitivity to the locomotor stimulant, rewarding, and reinforcing effects of MA. In addition, $\mathrm{H}^{+/-}$mice show an increase in hnRNP H protein in the striatal synaptosome, with no change in total hnRNP H. This increased localization of synaptosome hnRNP H is associated with an increase in complex I mitochondrial proteins. RBPs, such as hnRNP $\mathrm{H}$, chaperone mRNAs to membrane-bound organelles, such as the mitochondria for translation and subsequent assembly in the mitochondria. In the absence of MA, hnRNP $H$ binds to mRNA transcripts encoding mitochondria proteins and transports them to the surface of the mitochondria. MA administration disrupts hnRNP H-RNA interactions, which results in fewer mitochondrial mRNAs being transported to the mitochondria for translation.

targeting RNA elements to form higher-order units called mRNA ribonucleoprotein (RNP) complexes consisting of mRNAs and associated RBPs (Béthune et al., 2019; Rossoll and Bassell, 2019). The robust increase in hnRNP H protein in the striatal synaptosome accompanied by the increase in several complex I subunits suggests a novel function for hnRNP $\mathrm{H}$ in targeting mRNAs encoding for subunits of mitochondrial complex I to the mitochondria, thus regulating local translation (Fig. 24). Once the mRNAs are transported nearby the mitochondria, hnRNP H could coordinate with other RBPs to form a ribonucleoprotein (RNP) complex to stabilize mRNAs to the mitochondrial membrane where translational activators initiate translation. An example of an RBP with such function is Puf3pm, which binds to ATP2 mRNA encoding mitochondrial components of the $\mathrm{F}_{1} \mathrm{~F}_{0}$ ATPase and localizes to the outer mitochondrial membrane (García-Rodríguez et al., 2007). Future studies involving cross-linking immunoprecipitation combined with RNA-seq (CLIP-seq) will identify target mRNAs bound to hnRNP $\mathrm{H}$ and determine the degree of enrichment for mRNAs encoding mitochondrial complex I subunits.

Mitochondria are abundant at the synapse where they generate ATP for $\mathrm{Ca}^{2+}$ buffering, vesicle release, and recycling (Vos et al., 2010; Devine and Kittler, 2018). Mitochondria consist of five oxidative phosphorylation complexes (I-V) (Sharma et al., 2009; Mimaki et al., 2012). Complex I is the first enzyme of the respiratory chain and initiates electron transport continuing to complex II-IV to generate redox energy for Complex $\mathrm{V}$ to produce ATP. The increase in Complex I subunits in $\mathrm{H}^{+/-}$mice could increase Complex I activity and synaptic ATP production to support vesicle fusion, DA release, and DA transport back into the cells via DAT and $\mathrm{Na}^{+} / \mathrm{K}^{+}$ATPase to counteract MA-induced $D A$ release. We found a Genotype $\times$ Treatment effect on protein levels of $\mathrm{F}_{0} \mathrm{~F}_{1}$ ATP synthase subunits (Atp5a1, ATP5f1, and Atp5o) of Complex V (Fig. 22) in the synaptosomal proteome whereby MA decreased these ATP synthase subunits in $\mathrm{H} 1^{+/-}$ mice, which could decrease ATP production in response to MA in $\mathrm{H} 1^{+/-}$mice and affect extracellular DA levels.

In addition to binding and targeting RNAs to the mitochondria for translation, hnRNP H, like other RBPs, could bind and target proteins via its glycine-rich domain in an activity-dependent manner (Tiruchinapalli et al., 2008). In an animal model for frontotemporal dementia, ploy(GR) aggregates (resulting from hexanucleotide repeats in C9ORF72) bind to mitochondrial complex V protein ATP5A1 to increase its ubiquitination and degradation through the proteasome pathway, thus disrupting mitochondrial function (Choi et al., 2019). The higher level of synaptosomal hnRNP $\mathrm{H}$ protein in $\mathrm{H}^{+/-}$mice could increase binding to mitochondrial complex I and $\mathrm{V}$ proteins (e.g., via the glycine-rich domain) to prevent degradation, yielding higher protein levels at baseline (Figs. 21, 22). MA administration could then decrease hnRNP $\mathrm{H}$-protein interactions in $\mathrm{H}^{+/-}$mice, thus decreasing synaptic mitochondrial proteins and synaptic function.

Together, the opposing effects of MA treatment on synaptic abundance of mitochondrial complex I proteins between $\mathrm{H} 1^{+/-}$ and WT mice could represent a mechanism underlying blunted 
MA-induced DA release in $\mathrm{H}^{+/-}$mice. Future studies will focus on the interaction between hnRNP $\mathrm{H}$ and mRNA encoding mitochondrial complex I and $\mathrm{V}$ subunits at the protein-RNA and protein-protein level (presynaptically and postsynaptically) and determine whether disruption of such interactions can alter ATP production and DA release.

\section{References}

Adinoff B (2004) Neurobiologic processes in drug reward and addiction. Harv Rev Psychiatry 12:305-320.

Arhin GK, Boots M, Bagga PS, Milcarek C, Wilusz J (2002) Downstream sequence elements with different affinities for the $\mathrm{hnRNP} \mathrm{H} / \mathrm{H}^{\prime}$ protein influence the processing efficiency of mammalian polyadenylation signals. Nucleic Acids Res 30:1842-1850.

Bain JM, Cho MT, Telegrafi A, Wilson A, Brooks S, Botti C, Gowans G, Autullo LA, Krishnamurthy V, Willing MC, Toler TL, Ben-Zev B, Elpeleg O, Shen Y, Retterer K, Monaghan KG, Chung WK (2016) Variants in HNRNPH2 on the X chromosome are associated with a neurodevelopmental disorder in females. Am J Hum Genet 99:728-734.

Bernheim A, See RE, Reichel CM (2016) Chronic methamphetamine selfadministration disrupts cortical control of cognition. Neurosci Biobehav Rev 69:36-48.

Béthune J, Jansen RP, Feldbrügge M, Zarnack K (2019) Membraneassociated RNA-binding proteins orchestrate organelle-coupled translation. Trends Cell Biol 29:178-188.

Bosch PJ, Peng L, Kivell BM (2015) Proteomics analysis of dorsal striatum reveals changes in synaptosomal proteins following methamphetamine self-administration in rats. PLoS One 10:e0139829.

Burke RE, Cadet JL, Kent JD, Karanas AL, Jackson-Lewis V (1990) An assessment of the validity of densitometric measures of striatal tyrosine hydroxylase-positive fibers: relationship to apomorphine-induced rotations in 6-hydroxydopamine lesioned rats. J Neurosci Methods 35:63-73.

Chandra R, Engeln M, Schiefer C, Patton MH, Martin JA, Werner CT, Riggs LM, Francis TC, McGlincy M, Evans B, Nam H, Das S, Girven K, Konkalmatt P, Gancarz AM, Golden SA, Iñiguez SD, Russo SJ, Turecki G, Mathur BN, et al. (2017) Drp1 mitochondrial fission in D1 neurons mediates behavioral and cellular plasticity during early cocaine abstinence. Neuron 96:1327-1341.e6.

Chin MH, Qian WJ, Wang H, Petyuk VA, Bloom JS, Sforza DM, Laćan G, Liu D, Khan AH, Cantor RM, Bigelow DJ, Melega WP, Camp DG 2nd, Smith RD, Smith DJ (2008) Mitochondrial dysfunction, oxidative stress, and apoptosis revealed by proteomic and transcriptomic analyses of the striata in two mouse models of Parkinson's disease. J Proteome Res 7:666-677.

Choi SY, Lopez-Gonzalez R, Krishnan G, Phillips HL, Li AN, Seeley WW, Yao WD, Almeida S, Gao FB (2019) C9ORF72-ALS/FTD-associated poly(GR) binds Atp5a1 and compromises mitochondrial function in vivo. Nat Neurosci 22:851-862.

Chou MY, Rooke N, Turck CW, Black DL (1999) hnRNP H is a component of a splicing enhancer complex that activates a c-src alternative exon in neuronal cells. Mol Cell Biol 19:69-77.

Daubner SC, Le T, Wang S (2011) Tyrosine hydroxylase and regulation of dopamine synthesis. Arch Biochem Biophys 508:1-12.

Devine MJ, Kittler JT (2018) Mitochondria at the neuronal presynapse in health and disease. Nat Rev Neurosci 19:63-80.

DeYoung DZ, Heinzerling KG, Swanson AN, Tsuang J, Furst BA, Yi Y, Wu YN, Moody DE, Andrenyak DM, Shoptaw SJ (2016) Safety of intravenous methamphetamine administration during ibudilast treatment. J Clin Psychopharmacol 36:347-354.

Divakaruni SS, Van Dyke AM, Chandra R, LeGates TA, Contreras M, Dharmasri PA, Higgs HN, Lobo MK, Thompson SM, Blanpied TA (2018) Long-term potentiation requires a rapid burst of dendritic mitochondrial fission during induction. Neuron 100:860-875.e7.

Dunkley PR, Jarvie PE, Robinson PJ (2008) A rapid Percoll gradient procedure for preparation of synaptosomes. Nat Protoc 3:1718-1728.

Eastwood EC, Phillips TJ (2014) Morphine intake and the effects of naltrexone and buprenorphine on the acquisition of methamphetamine intake. Genes Brain Behav 13:226-235.

Eliyahu E, Pnueli L, Melamed D, Scherrer T, Gerber AP, Pines O, Rapaport D, Arava Y (2010) Tom 20 mediates localization of mRNAs to mitochondria in a translation-dependent manner. Mol Cell Biol 30:284-294.

Faul F, Erdfelder E, Lang AG, Buchner A (2007) G*Power 3: a flexible sta- tistical power analysis program for the social, behavioral, and biomedical sciences. Behav Res Methods 39:175-191.

Faure JJ, Hattingh SM, Stein DJ, Daniels WM (2009) Proteomic analysis reveals differentially expressed proteins in the rat frontal cortex after methamphetamine treatment. Metab Brain Dis 24:685-700.

García-Rodríguez LJ, Gay AC, Pon LA (2007) Puf3p, a pumilio family RNA binding protein, localizes to mitochondria and regulates mitochondrial biogenesis and motility in budding yeast. J Cell Biol 176:197-207.

Gehrke S, Wu Z, Klinkenberg M, Sun Y, Auburger G, Guo S, Lu B (2015) PINK1 and parkin control localized translation of respiratory chain component mRNAs on mitochondria outer membrane. Cell Metab 21:95-108.

Gerber AP, Herschlag D, Brown PO (2004) Extensive association of functionally and cytotopically related mRNAs with puf family RNA-binding proteins in yeast. PLoS Biol 2:E79.

Grammatikakis I, Zhang P, Panda AC, Kim J, Maudsley S, Abdelmohsen K, Yang X, Martindale JL, Motiño O, Hutchison ER, Mattson MP, Gorospe M (2016) Alternative splicing of neuronal differentiation factor TRF2 regulated by HNRNPH1/H2. Cell Rep 15:926-934.

Haughey HM, Fleckenstein AE, Metzger RR, Hanson GR (2000) The effects of methamphetamine on serotonin transporter activity. J Neurochem 75:1608-1617.

Honoré B, Rasmussen HH, Vorum H, Dejgaard K, Liu X, Gromov P, Madsen P, Gesser B, Tommerup N, Celis JE (1995) Heterogeneous nuclear ribonucleoproteins $\mathrm{H}, \mathrm{H}^{\prime}$, and $\mathrm{F}$ are members of a ubiquitously expressed subfamily of related but distinct proteins encoded by genes mapping to different chromosomes. J Biol Chem 270:28780-28789.

Honoré B, Vorum H, Baandrup U (1999) hnRNPs H, H' and F behave differently with respect to posttranslational cleavage and subcellular localization. FEBS Lett 456:274-280.

Hooks MS, Jones GH, Smith AD, Neill DB, Justice JB Jr (1991) Individual differences in locomotor activity and sensitization. Pharmacol Biochem Behav 38:467-470.

Hutson CB, Lazo CR, Mortazavi F, Giza CC, Hovda D, Chesselet MF (2011) Traumatic brain injury in adult rats causes progressive nigrostriatal dopaminergic cell loss and enhanced vulnerability to the pesticide paraquat. J Neurotrauma 28:1783-1801.

Iwazaki T, McGregor IS, Matsumoto I (2006) Protein expression profile in the striatum of acute methamphetamine-treated rats. Brain Res 1097:19 25.

Iwazaki T, McGregor IS, Matsumoto I (2007) Protein expression profile in the striatum of rats with methamphetamine-induced behavioral sensitization. Proteomics 7:1131-1139.

Kamma H, Portman DS, Dreyfuss G (1995) Cell type-specific expression of hnRNP proteins. Exp Cell Res 221:187-196.

Katz Y, Wang ET, Airoldi EM, Burge CB (2010) Analysis and design of RNA sequencing experiments for identifying isoform regulation. Nat Methods 7:1009-1015.

Keleta YB, Martinez JL (2012) Brain circuits of methamphetamine place reinforcement learning: the role of the hippocampus-VTA loop. Brain Behav 2:128-141.

Kirkpatrick SL, Bryant CD (2015) Behavioral architecture of opioid reward and aversion in C57BL/6 substrains. Front Behav Neurosci 8:450.

Kivell B, Uzelac Z, Sundaramurthy S, Rajamanickam J, Ewald A, Chefer V, Jaligam V, Bolan E, Simonson B, Annamalai B, Mannangatti P, Prisinzano TE, Gomes I, Devi LA, Jayanthi LD, Sitte HH, Ramamoorthy S, Shippenberg TS (2014) Salvinorin A regulates dopamine transporter function via a kappa opioid receptor and ERK1/2-dependent mechanism. Neuropharmacology 86:228-240.

Lein ES, Hawrylycz MJ, Ao N, Ayres M, Bensinger A, Bernard A, Boe AF, Boguski MS, Brockway KS, Byrnes EJ, Chen L, Chen L, Chen TM, Chin MC, Chong J, Crook BE, Czaplinska A, Dang CN, Datta S, Dee NR, et al. (2007) Genome-wide atlas of gene expression in the adult mouse brain. Nature 445:168-176.

Liao PC, Kuo YM, Hsu HC, Cherng CG, Yu L (2005) Local proteins associated with methamphetamine-induced nigrostriatal dopaminergic neurotoxicity. J Neurochem 95:160-168.

Li Z, Okamoto K, Hayashi Y, Sheng M (2004) The importance of dendritic mitochondria in the morphogenesis and plasticity of spines and synapses. Cell 119:873-887.

Lipari RN, Park-Lee E, Van Horn S (2016) America's need for and receipt of substance use treatment in 2015. In: CBHSQ Report, pp 2013-2016. 
Rockville, MD: Substance Abuse and Mental Health Services Administration.

Livak KJ, Schmittgen TD (2001) Analysis of relative gene expression data using real-time quantitative PCR and the $2-\Delta \Delta C T$ method. Methods 25:402-408.

Lominac KD, McKenna CL, Schwartz LM, Ruiz PN, Wroten MG, Miller BW, Holloway JJ, Travis KO, Rajasekar G, Maliniak D, Thompson AB, Urman LE, Phillips TJ, Szumlinski KK (2014) Mesocorticolimbic monoamine correlates of methamphetamine sensitization and motivation. Front Syst Neurosci 8:70.

Lominac KD, Quadir SG, Barrett HM, McKenna CL, Schwartz LM, Ruiz PN, Wroten MG, Campbell RR, Miller BW, Holloway JJ, Travis KO, Rajasekar G, Maliniak D, Thompson AB, Urman LE, Kippin TE, Phillips TJ, Szumlinski KK (2016) Prefrontal glutamate correlates of methamphetamine sensitization and preference. Eur J Neurosci 43:689-702.

Mimaki M, Wang X, McKenzie M, Thorburn DR, Ryan MT (2012) Understanding mitochondrial complex I assembly in health and disease. Biochim Biophys Acta 1817:851-862.

Njung'e K, Handley SL (1991) Evaluation of marble-burying behavior as a model of anxiety. Pharmacol Biochem Behav 38:63-67.

Oettinghaus B, Schulz JM, Restelli LM, Licci M, Savoia C, Schmidt A, Schmitt K, Grimm A, Morè L, Hench J, Tolnay M, Eckert A, D'Adamo P, Franken P, Ishihara N, Mihara K, Bischofberger J, Scorrano L, Frank S (2016) Synaptic dysfunction, memory deficits and hippocampal atrophy due to ablation of mitochondrial fission in adult forebrain neurons. Cell Death Differ 23:18-28.

Paxinos G, Franklin KB (2001) Paxinos and Franklin's the mouse brain in stereotaxic coordinates, Ed 2. San Diego: Academic.

Pilch J, Koppolu AA, Walczak A, Murcia Pienkowski VA, Biernacka A, Skiba P, Machnik-Broncel J, Gasperowicz P, Kosińska J, Rydzanicz M, EmichWidera E, Płoski R (2018) Evidence for HNRNPH1 being another gene for Bain type syndromic mental retardation. Clin Genet 94:381-385.

Porsolt RD, Le Pichon M, Jalfre M (1977) Depression: a new animal model sensitive to antidepressant treatments. Nature 266:730-732.

Prus AJ, James JR, Rosecrans JA (2009) Conditioned place preference. In: Methods of behavior analysis in neuroscience (Buccafusco J, ed), Ed 2. Boca Raton, FL: CRC/Taylor and Francis.

Reimand J, Isserlin R, Voisin V, Kucera M, Tannus-Lopes C, Rostamianfar A, Wadi L, Meyer M, Wong J, Xu C, Merico D, Bader GD (2019) Pathway enrichment analysis and visualization of omics data using g:Profiler, GSEA, Cytoscape and EnrichmentMap. Nat Protoc 14:482-517.

Rossoll W, Bassell GJ (2019) Crosstalk of local translation and mitochondria: powering plasticity in axons and dendrites. Neuron 101:204-206.

Rothman RB, Baumann MH, Dersch CM, Romero DV, Rice KC, Carroll FI, Partilla JS (2001) Amphetamine-type central nervous system stimulants release norepinephrine more potently than they release dopamine and serotonin. Synapse 39:32-41.

Segal DS, Kuczenski R (1997) Repeated binge exposures to amphetamine and methamphetamine: behavioral and neurochemical characterization. J Pharmacol Exp Ther 282:561-573.

Sharma LK, Lu J, Bai Y (2009) Mitochondrial respiratory complex: I. Structure, function and implication in human diseases. Curr Med Chem 16:1266-1277.

Slawson MH, Taccogno JL, Foltz RL, Moody DE (2002) Quantitative analysis of selegiline and three metabolites (N-desmethylselegiline, methamphetamine, and amphetamine) in human plasma by high performance liquid chromatography-atmospheric pressure chemical ionizationtandem mass spectrometry. J Anal Toxicol 26:430-437.
Song KY, Choi HS, Law PY, Wei LN, Loh HH (2017) Post-transcriptional regulation of the human mu-opioid receptor (MOR) by morphineinduced RNA binding proteins hnRNP K and PCBP1. J Cell Physiol 232:576-584.

Staal RG, Ray S, Sulzer D (2007) Terminals amperometric detection of dopamine exocytosis from synaptic introduction to dopamine neurotransmission. In: Electrochemical methods for neuroscience (Michael A, Borland L, eds). Boca Raton, FL: CRC/Taylor and Francis.

Szumlinski KK, Lominac KD, Kleschen MJ, Oleson EB, Dehoff MH, Schwarz MK, Seeburg PH, Worley PF, Kalivas PW (2005) Behavioral and neurochemical phenotyping of Homer1 mutant mice: possible relevance to schizophrenia. Genes Brain Behav 4:273-288.

Szumlinski KK, Lominac KD, Campbell RR, Cohen M, Fultz EK, Brown CN, Miller BW, Quadir SG, Martin D, Thompson AB, von Jonquieres G, Klugmann M, Phillips TJ, Kippin TE (2017) Methamphetamine addiction vulnerability: the glutamate, the bad and the ugly. Biol Psychiatry 81:959-970.

Tiruchinapalli DM, Ehlers MD, Keene JD (2008) Activity-dependent expression of RNA binding protein $\mathrm{HuD}$ and its association with mRNAs in neurons. RNA Biol 5:157-168.

Uhl GR, Drgonova J, Hall FS (2014) Curious cases: altered dose-response relationships in addiction genetics. Pharmacol Ther 141:335-346.

Van Dusen CM, Yee L, McNally LM, McNally MT (2010) A glycine-rich domain of hnRNP H/F promotes nucleocytoplasmic shuttling and nuclear import through an interaction with transportin 1. Mol Cell Biol 30:2552-2562.

Vos M, Lauwers E, Verstreken P (2010) Synaptic mitochondria in synaptic transmission and organization of vesicle pools in health and disease. Front Synaptic Neurosci 2:139.

Wang E, Dimova N, Cambi F (2007) PLP/DM20 ratio is regulated by hnRNPH and F and a novel G-rich enhancer in oligodendrocytes. Nucleic Acids Res 35:4164-4178.

Wang E, Aslanzadeh V, Papa F, Zhu H, de la Grange P, Cambi F (2012) Global profiling of alternative splicing events and gene expression regulated by hnRNPH/F. PLoS One 7:e52166.

Williams CC, Jan CH, Weissman JS (2014) Targeting and plasticity of mitochondrial proteins revealed by proximity-specific ribosome profiling. Science 346:748-751.

Witten JT, Ule J (2011) Understanding splicing regulation through RNA splicing maps. Trends Genet 27:89-97.

Yamamoto DJ, Nelson AM, Mandt BH, Larson GA, Rorabaugh JM, Ng CM, Barcomb KM, Richards TL, Allen RM, Zahniser NR (2013) Rats classified as low or high cocaine locomotor responders: a unique model involving striatal dopamine transporters that predicts cocaine addiction-like behaviors. Neurosci Biobehav Rev 37:1738-1753.

Yazdani N, Parker CC, Shen Y, Reed ER, Guido MA, Kole LA, Kirkpatrick SL, Lim JE, Sokoloff G, Cheng R, Johnson WE, Palmer AA, Bryant CD (2015) Hnrnph1 is a quantitative trait gene for methamphetamine sensitivity. PLoS Genet 11:e1005713.

Yoon Y, McKenna MC, Rollins DA, Song M, Nuriel T, Gross SS, Xu G, Glatt CE (2013) Anxiety-associated alternative polyadenylation of the serotonin transporter mRNA confers translational regulation by hnRNPK. Proc Natl Acad Sci U S A 110:11624-11629.

Zaniewska M, Filip M, Przegalinski E (2015) The involvement of norepinephrine in behaviors related to psychostimulant addiction. Curr Neuropharmacol 13:407-418. 